\title{
Mechanistic Investigation on the Polymerization of Phenylacetylene by 2-Diphenylphosphinopyridine Rhodium(I) Catalysts: Understand- ing the Role of the Cocatalyst and Alkynyl Intermediates
}

\author{
Marta Angoy, ${ }^{\dagger}$ M. Victoria Jiménez, ${ }^{*} \dagger$ F. Javier Modrego,${ }^{\dagger}$ Luis A. Oro, ${ }^{\dagger}$ Vincenzo Passarelli, ${ }^{\ddagger}$ and \\ Jesús J. Pérez-Torrente, ${ }^{*} \dagger$ \\ † Departamento de Química Inorgánica, Instituto de Síntesis Química y Catálisis Homogénea-ISQCH, Universidad \\ de Zaragoza-CSIC, Facultad de Ciencias, C/ Pedro Cerbuna, 12, 50009 Zaragoza, Spain.
}

‡ Centro Universitario de la Defensa, Ctra. Huesca s/n, ES-50ogo Zaragoza, Spain

Supporting Information Placeholder

\begin{abstract}
The mono- and dinuclear rhodium(I) complexes featuring a 2-(diphenylphosphino)pyridine ligand, $\left[\mathrm{Rh}(\operatorname{cod})\left(\mathrm{Ph}_{2} \mathrm{PPy}\right)\right]^{+}$and $\left[\mathrm{Rh}(\mathrm{nbd})\left(\mathrm{Ph}_{2} \mathrm{PPy}\right)\right]_{2}{ }_{2}^{2+}(\operatorname{cod}=1,5$-cyclooctadiene, $\mathrm{nbd}=2,5$-norbornadiene $)$, have been prepared in order to be evaluated as phenylacetylene (PA) polymerization catalysts. In contrast with compound $\left[\mathrm{Rh}(\mathrm{nbd})\left\{\mathrm{Ph}_{2}\left(\mathrm{CH}_{2}\right)_{2} \mathrm{Py}\right\}\right]^{+}$, featuring 2-(2-(diphenylphosphino)ethyl)pyridine ligand, that showed a moderate catalytic activity both 2-(diphenylphosphino)pyridine complexes were completely inactive due to the formation of unusual dinuclear species $\left[\mathrm{Rh}_{2}(\text { diene })_{2}\left(\mu-\mathrm{Ph}_{2} \mathrm{PPy}\right)(\mu-\mathrm{C} \equiv \mathrm{C}-\mathrm{R})\right]^{+}$, featuring a $\mathrm{Ph}_{2} \mathrm{PPy}$ bridging ligand and an alkynyl ligand coordinated in a $\mu-\eta^{1}: \eta^{2}$ fashion, which are inactive in PA polymerization. However, in the presence of a cocatalyst as $i \operatorname{PrH}_{2}$ compounds $\left[\mathrm{Rh} \text { (diene) }\left(\mathrm{Ph}_{2} \mathrm{PPy}\right)\right]_{\mathrm{n}}^{\mathrm{n}+}$ efficiently polymerize $\mathrm{PA}$ affording highly stereoregular polyphenylacetylenes of $M_{\mathrm{w}} 3.42 \mathrm{E}+05$ (cod) and 2.02E+05 (nbd), with polydispersities of 1.39 and initiation efficiencies of 4-7\%. NMR studies on the polymerization reaction have allow to identify the alkynyl species $\left[\mathrm{Rh}(\mathrm{C} \equiv \mathrm{CPh})(\operatorname{cod})\left(\mathrm{Ph}_{2} \mathrm{PPy}\right)\right]$ as the likely initiating species involved in the generation of the rhodium-vinyl species responsible for the propagation step. The $i \mathrm{PrNH}_{2}$ cocatalyst is likely involved in the efficient proton transfer from the coordinated PA to $i \mathrm{PrNH}_{2}$ that allows for a significant concentration of the key initiating species $\left[\mathrm{Rh}(\mathrm{C} \equiv \mathrm{CPh})(\operatorname{cod})\left(\mathrm{Ph}_{2} \mathrm{PPy}\right)\right]$. The distinct behavior of compounds $\left[\mathrm{Rh}(\text { diene })\left(\mathrm{Ph}_{2} \mathrm{PPy}\right)\right]_{\mathrm{n}}{ }^{\mathrm{n}+}$ as $\mathrm{PA}$ polymerization catalysts is a consequence of the binucleating ability of the $\mathrm{Ph}_{2} \mathrm{PPy}$ ligand in combination with the lower basicity of the pyridine fragment which allows for the stabilization of the inactive alkynyl-bridge dinuclear species.
\end{abstract}

\section{INTRODUCTION}

The commercially available 2(diphenylphosphino)pyridine $\left(\mathrm{Ph}_{2} \mathrm{PPy}\right)$ is a versatile and easily tuneable ligand with a quite rigid structure that exhibits a rich coordination chemistry., ${ }^{1,23}$ This heteroditopic ligand can coordinate to metal fragments in different ways: monodentate $\left(\kappa^{1} P\right.$ or $\left.\kappa^{1} N\right),{ }^{4,5}$ bidentate chelate $\left(\kappa^{2} P, N\right)^{6,7}$ or bridging $(1 \kappa P, 2 \kappa N)$ rendering homo- or heterodinuclear compounds, ${ }^{8}$ oligomer compounds or even clusters, ${ }^{9,10,11,12}$ depending on the requirements at the metal center. The electronic differentiation associated with the soft phosphorus and hard nitrogen donors frequently directs both its reactivity and coordination behavior what make it particularly attractive not only for materials or coordination chemistry, but also in homogeneous catalysis. ${ }^{13}$ The hard/soft combination can lead to selective binding of metal ions in different oxidation states and more importantly to create potential vacant sites at the metal center due to hemilability. ${ }^{3,8}$ Furthermore, the presence of an uncoordinated pyridyl ring enables the establishment of hydrogen bonds or the participation in proton transfer processes what has allowed the development of new bifunctional catalysts based on $\kappa^{1} P$ pyridylphosphine metal complexes. ${ }^{14,15}$ In this context, the ability of the nitrogen atom of the pyridyl fragment to activate a reactant molecule such as water through a secondary hydrogen-bonding interaction enhances activity and selectivity in the ruthenium-catalyzed hydration of nitriles $^{16,17,18}$ and anti-Markovnikov hydration of alkynes, ${ }^{19,20,21}$ what have stimulated an intense research in this field. In fact, related ruthenium bifunctional catalysts based on imidazolyl-functionalized phosphine ligands have also found application in catalytic alkene isomerization and deuteration reactions. ${ }^{22,23}$ In addition, transition metal complexes bearing related phosphine-Nheterocycle (pyridine, imidazole) ligands undergo facile intramolecular $\mathrm{C}-\mathrm{H}$ bond activation processes in the ligand scaffold. ${ }^{24}$

The chelate bidentate coordination of the $\mathrm{Ph}_{2} \mathrm{PPy}$ ligand gives rise to a relative strained four-membered metallacycle which stabilizes some crucial intermediates in 
several processes catalyzed by the system $\mathrm{Pd}(\mathrm{OAc})_{2} / \mathrm{PPh}_{2} \mathrm{Py} / \mathrm{H}^{+}$such as the methoxycarbonylation of propyne, ${ }^{25}$ the hydrocarboxylation of acetylene ${ }^{26}$ or the alkoxycarbonylation of alkynols. ${ }^{27}$ However, the key of the high efficiency of these catalytic systems is likely the active role of the ligand as a proton messenger $\left(\mathrm{P}-\mathrm{N} / \mathrm{P}-\mathrm{NH}^{+}\right)$ promoting fundamental steps of the catalytic cycle.

Polyphenylacetylene (PPA) is an air stable stiff polymer chain with semi-conductor properties. Interestingly, the rational choice of substituted acetylenes has directed the preparation of functional polymers, stimuli-responsive materials and gas separation membranes. ${ }^{28,29}$ Late transition metal based catalysts have drawn considerable attention because of their high activity, high tolerance towards air and moisture, and the relatively wide range of applicable monomers. In particular, rhodium catalysts efficiently catalyze the polymerization of monosubstituted acetylenes with formation of highly stereoregular polymers, in some cases in a living manner. ${ }^{30,31}$ We have reported a study on the screening of cationic rhodium(I) complexes $\left[\mathrm{Rh} \text { (diene) }\left\{\mathrm{Ph}_{2} \mathrm{P}\left(\mathrm{CH}_{2}\right)_{n} \mathrm{Z}\right\}\right]^{+}$(diene $=1,5$-cyclooctadiene, cod; tetrafluorobenzobarralene, $\mathrm{tfb}$; or 2,5-norbonadiene, nbd) containing functionalized phosphine ligands of hemilabile character of the type $\mathrm{Ph}_{2} \mathrm{P}\left(\mathrm{CH}_{2}\right)_{n} \mathrm{Z}(n=2$, or 3; $\mathrm{Z}=\mathrm{OMe}, \mathrm{NMe}_{2}, \mathrm{SMe}$ ). In general, this catalysts exhibit a great activity for phenylacetylene (PA) polymerization affording very high molecular weight PPA with moderate polydispersity indexes at high conversion. ${ }^{32}$ The PPA obtained with these catalytic systems shows a cis-transoidal configuration with a high level of steroregularity (cis content superior to 99\%). Characterization of PPA samples produced with these rhodium catalysts by size exclusion chromatography, multi-angle light scattering (SECMALS), or asymmetric flow field flow fractionation ( $\mathrm{A}_{4} \mathrm{~F}-$ MALS) has revealed that some of these PPA samples contain a mixture of linear and branched polymer. The occurrence and extent of branching is dependent on both catalyst structure and polymerization conditions. ${ }^{33}$ Mechanistic investigations on $\mathrm{PA}$ polymerization by the catalyst precursor $\left[\mathrm{Rh}(\mathrm{cod})\left\{\mathrm{Ph}_{2} \mathrm{P}\left(\mathrm{CH}_{2}\right)_{3} \mathrm{NMe}_{2}\right\}\right]^{+}$led us to the identification of a Rh-alkynyl species which is formed by the intramolecular proton transfer from a $\eta^{2}$-alkyne ligand to the uncoordinated $-\mathrm{NMe}_{2}$ group (Figure 1). This cationic alkynyl intermediate is the initiating species most likely involved in the generation of very stable rhodium-vinyl species responsible for the propagation step..$^{32}$

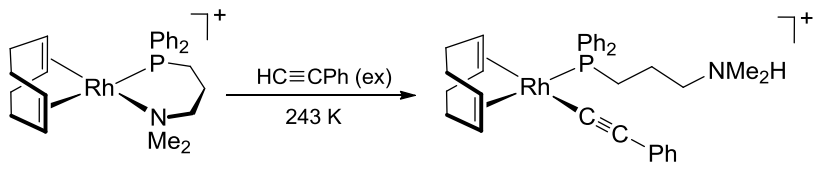

Figure 1. Formation of a Rh-alkynyl species triggered by a hemilabile phosphine ligand.

PA polymerization studies by rhodium(I) initiators have shown that the presence of a base as co-catalyst, as for example 4-(dimethylamino)pyridine (DMPA) or $i-\mathrm{PrNH}_{2}$, usually results in an improvement of the catalyst performance as a result of an increase of the initiation efficien$\mathrm{cy}^{34,35,36}$ or the inhibition of usual catalyst deactivation pathways. ${ }^{37} \quad$ Interestingly, the catalysts $\left[\mathrm{Rh} \text { (diene) }\left\{\mathrm{Ph}_{2} \mathrm{P}\left(\mathrm{CH}_{2}\right)_{3} \mathrm{NMe}_{2}\right\}\right]^{+}$induced the quasi-living polymerization of $\mathrm{PA}$ in the presence of DMAP affording a PPA of lower molecular weight and narrow polydispersity index.

On the light of these precedents on the positive effect of an external- or internal-base in the efficiency of PA polymerization, we envisage the potential of rhodium(I) polymerization catalysts based on $\mathrm{Ph}_{2} \mathrm{PPy}$ ligands due to the presence of a basic pyridyl fragment. We report herein on the synthesis of neutral and cationic $\mathrm{Rh}$ (diene) $/ \mathrm{Ph}_{2} \mathrm{PPy}$ complexes and their application as $\mathrm{PA}$ polymerization catalysts. Against the initial expectations, the cationic complexes $\left[\mathrm{Rh} \text { (diene) }\left(\mathrm{Ph}_{2} \mathrm{PPy}\right)\right]_{\mathrm{n}}{ }^{\mathrm{n}+}$ were inactive although in the presence of $i-\mathrm{PrNH}_{2}$ efficiently polymerized PA. These preliminary results prompted us to develop reactivity studies in order to unveil the catalyst deactivation processes and the role of the base cocatalyst.

\section{RESULTS AND DISCUSSION}

Synthesis and catalytic activity in PA polymerization of complexes $\left[\mathrm{RhCl}(\right.$ diene $\left.)\left(\mathrm{Ph}_{2} \mathrm{PPy}\right)\right]$ (diene = cod, $\mathrm{nbd})$ and $\left[\mathrm{Rh}(\text { diene })\left(\mathrm{Ph}_{2} \mathrm{PPy}\right)\right]_{\mathrm{n}}{ }^{\mathrm{n}+}($ diene $=\operatorname{cod}, \mathrm{n}$ $=\mathbf{1}$; nbd, $\mathbf{n}=\mathbf{2}$ ). The neutral mononuclear compounds $\left[\mathrm{RhCl}(\mathrm{cod})\left(\mathrm{Ph}_{2} \mathrm{PPy}\right)\right]$ (1) and $\left[\mathrm{RhCl}(\mathrm{nbd})\left(\mathrm{Ph}_{2} \mathrm{PPy}\right)\right]$ (2) were prepared by reaction of the corresponding $[\mathrm{Rh}(\mu-$ $\mathrm{Cl})$ (diene) $]_{2}$ complex with $\mathrm{Ph}_{2} \mathrm{PPy}$ (1:2 molar ratio) following the synthetic procedure described by Faraone ${ }^{38}$ and Brück. ${ }^{39}$ The compounds have been characterized by comparison of their spectroscopic data with those described in the literature. The cationic complexes $\left[\mathrm{Rh}(\operatorname{cod})\left(\mathrm{Ph}_{2} \mathrm{PPy}\right)\right]\left[\mathrm{BF}_{4}\right] \quad$ (3) and $[\mathrm{Rh}(\mathrm{nbd})(\mu-$ $\left.\left.\mathrm{Ph}_{2} \mathrm{PPy}\right)\right]_{2}\left[\mathrm{BF}_{4}\right]_{2}$ (4) were prepared by reaction of $\mathrm{Ph}_{2} \mathrm{PPy}$ with the corresponding solvato $\left.[\mathrm{Rh} \text { (diene)(THF) }]_{2}\right]^{+}$species formed in situ in tetrahydrofuran. Both compounds were isolated as yellow and violet microcrystalline solids, respectively, with yields of around $70 \%$ (Chart 1 ).

\section{Chart 1. Structures of compounds 1-6.}




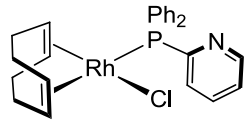

1

3

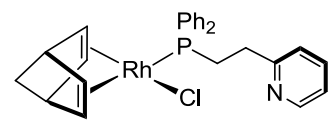

5

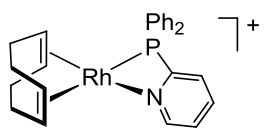

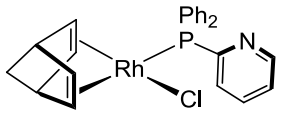

2
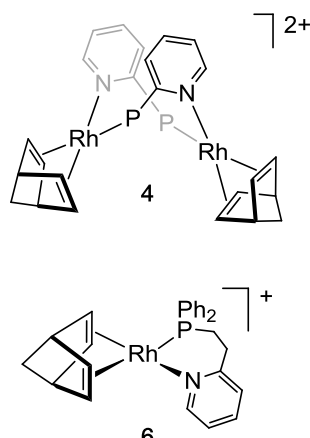

6
The ${ }^{31} \mathrm{P}\left\{{ }^{1} \mathrm{H}\right\}$ NMR spectrum of 3 in $\mathrm{CD}_{2} \mathrm{Cl}_{2}$ at $193 \mathrm{~K}$ showed a high-field shifted doublet at $\delta-40.03 \mathrm{ppm}\left(J_{\mathrm{Rh}-\mathrm{P}}\right.$ $=126.0 \mathrm{~Hz}$ ) which is characteristic of the chelating bidentate $\kappa^{2} P, N$ coordination mode of the $\mathrm{Ph}_{2} \mathrm{PPy}$ ligand. ${ }^{39,40,41}$ On the other hand, two broad resonances were observed for the olefin $=\mathrm{CH}$ protons and carbons in the ${ }^{1} \mathrm{H}$ and ${ }^{13} \mathrm{C}\left\{{ }^{1} \mathrm{H}\right\}$ NMR spectra respectively, which is in agreement with a mononuclear structure of $C_{\mathrm{S}}$ symmetry. However, the ${ }^{31} \mathrm{P}\left\{{ }^{1} \mathrm{H}\right\}$ NMR spectrum of 4 in $\mathrm{CD}_{2} \mathrm{Cl}_{2}$ at $233 \mathrm{~K}$ showed a doublet at $\delta 20.62 \mathrm{ppm}\left(J_{\mathrm{Rh}-\mathrm{P}}=158.8 \mathrm{~Hz}\right)$ which is not compatible with a $\kappa^{2} P, N$ coordination. In fact, the number of resonances in the olefin region of the ${ }^{1} \mathrm{H}$ and ${ }^{13} \mathrm{C}\left\{{ }^{1} \mathrm{H}\right\}$ NMR spectra suggests a dinuclear structure supported by two $\mathrm{Ph}_{2} \mathrm{PPy}$ bridging ligands in a head-to-tail disposition. In agreement with a $C_{2}$ symmetry, the $=\mathrm{CH}$ protons and carbons of the equivalent norbornadiene ligands give rise to four broad resonances both in the ${ }^{1} \mathrm{H}$ NMR and ${ }^{13} \mathrm{C}\left\{{ }^{1} \mathrm{H}\right\}$ NMR spectra. Besides, the equivalent $\mathrm{H}-6$ protons of the pyridine fragments appear as a doublet at $\delta 9.11 \mathrm{ppm}$, shifted to low field compared with that of the mononuclear compound 3 which is observed at $8.10 \mathrm{ppm}$. This shifting may arise from proximity effects to the metal center associated with the bridging coordination mode of the $\mathrm{Ph}_{2} \mathrm{PPy}$ ligands as it has been observed in related dinuclear complexes supported by short-bite binucleating ligands. ${ }^{42}$ Although the MALDI-Tof mass spectra of 3 and 4 only show a peak with a $\mathrm{m} / \mathrm{z}$ corresponding to the mononuclear fragment $\left[\mathrm{Rh}(\text { diene })\left(\mathrm{Ph}_{2} \mathrm{PPy}\right)\right]^{+}$, the nuclearity of both compounds was confirmed by conductivity measurements in acetone solutions. The values of molar conductivity of 84 and $171 \Omega^{-1} \mathrm{~cm}^{2} \mathrm{~mol}^{-1}$ are in agreement with the expected values for 1:1 and 1:2 electrolytes, respectively.

The different nuclearity of both compounds might be associated to the steric repulsion of the diene ligands in the pocket of the dinuclear structure supported by the two short-bite 2-(diphenylphosphino)pyridine ligands. Thus, the smaller nbd ligands can be easily accommodated in the pocket by twisting of both rhodium coordination planes but no the bulky cod ligands thereby resulting in the formation of a mononuclear complex. The relative stability of compounds of formulation $[\mathrm{Rh}$ (diene $\left.)\left(\mathrm{Ph}_{2} \mathrm{PPy}\right)\right]^{+}$in both monomeric and dimeric forms has been calculated. A dinuclear $\left[\mathrm{Rh}(\operatorname{cod})\left(\mathrm{Ph}_{2} \mathrm{PPy}\right)\right]_{2}{ }^{2+}$ species results less stable than its monomer 3 by $\Delta \mathrm{G}=+24.13 \mathrm{kcal} \mathrm{mol}^{-1}$ while for $\left[\mathrm{Rh}(\mathrm{nbd})\left(\mathrm{Ph}_{2} \mathrm{PPy}\right)\right]_{2}{ }^{2+}$ the difference is just of $+15.51 \mathrm{kcal}$ $\mathrm{mol}^{-1}$. Avoiding the entropy penalty, which favors the monomers, by comparing just the electronic energy, results in the cod dimer being still $0.4 \mathrm{kcal} \mathrm{mol}^{-1}$ less stable than its monomer 3 but for the nbd analog is the dimer the most stable form by $5.19 \mathrm{kcal} \mathrm{mol}^{-1}$ which reflects the lesser steric requirements of nbd compared to cod.

Related complexes having the pyridine-functionalized phosphine 2-(2-(diphenylphosphino)ethyl)pyridine, $\mathrm{Ph}_{2} \mathrm{P}\left(\mathrm{CH}_{2}\right)_{2} \mathrm{Py}$, have been also prepared with the aim to evaluate and compare their catalytic activity in PA polymerization. The mononuclear complexes $\left[\mathrm{RhCl}(\mathrm{nbd})\left\{\mathrm{Ph}_{2} \mathrm{P}\left(\mathrm{CH}_{2}\right)_{2} \mathrm{Py}\right\}\right] \quad$ (5) and $\left[\mathrm{Rh}(\mathrm{nbd})\left\{\mathrm{Ph}_{2} \mathrm{P}\left(\mathrm{CH}_{2}\right)_{2} \mathrm{Py}\right\}\right] \mathrm{BF}_{4} \quad(6)^{43}$ were prepared from $[\mathrm{Rh}(\mu-\mathrm{Cl})(\mathrm{nbd})]_{2}$ and the solvato $\left[\mathrm{Rh}(\mathrm{nbd})(\mathrm{THF})_{2}\right]^{+}$species, respectively, following the same synthetic protocol applied for the synthesis of complexes 1-4 and isolated as orange solids in 6o-70 \% yield. Both complexes have been fully characterized by multinuclear NMR spectroscopy and mass spectra (MALDI-Tof). In particular, the NMR data are compatible with square-planar structures of $C_{\mathrm{s}}$ symmetry having a $\mathrm{Ph}_{2} \mathrm{P}\left(\mathrm{CH}_{2}\right)_{2} \mathrm{Py}$ ligand with $\kappa P$ and $\kappa^{2} P, N$ coordination modes, respectively (Chart 1 ).

PA polymerization reactions by catalyst precursors 1-6 were carried out in THF at $293 \mathrm{~K}$ using a monomer-torhodium ratio $[\mathrm{PA}]_{\mathrm{o}} /[\mathrm{Rh}]$ of 100 . The obtained PPAs have been characterized by size exclusion chromatography (SEC) using light-scattering (MALS) and refractive index (DRI) detectors (Table 1). The neutral complexes $\left[\mathrm{RhCl}(\mathrm{cod})\left(\mathrm{Ph}_{2} \mathrm{PPy}\right)\right]$ (1) and $\left[\mathrm{RhCl}(\mathrm{nbd})\left(\mathrm{Ph}_{2} \mathrm{PPy}\right)\right]$ (2) were moderately active affording PPAs with a weightaverage molecular weight, $M_{\mathrm{w}}$, of about $2.0 \mathrm{E}+05$ with moderate polydispersity indexes, $M_{\mathrm{w}} / M_{\mathrm{n}}$, of around 1.6 (entries 1 and 2). Catalyst 2 is considerably more active than 1 which is in agreement with the greater $\pi$-acceptor character of the diene nbd compared to cod. ${ }^{44,45}$ Compound $\left[\mathrm{RhCl}(\mathrm{nbd})\left\{\mathrm{Ph}_{2} \mathrm{P}\left(\mathrm{CH}_{2}\right)_{2} \mathrm{Py}\right\}\right]$ (5) exhibited a superior catalytic performance showing complete PA conversion in $2 \mathrm{~h}$. Interestingly, the PPA obtained has a high $M_{\mathrm{w}}$ of 2.04E+o6 and a $M_{\mathrm{W}} / M_{\mathrm{n}}$ of 1.63 (entry 7 ), of the same order of magnitude than the obtained with the cationic catalyst $\left[\mathrm{Rh}(\mathrm{nbd})\left\{\mathrm{Ph}_{2} \mathrm{P}\left(\mathrm{CH}_{2}\right)_{3} \mathrm{NMe}_{2}\right\}\right]^{+}$under the same conditions $\left(M_{\mathrm{W}}=2.18 \mathrm{E}+\mathrm{o6}, M_{\mathrm{W}} / M_{\mathrm{n}}\right.$ of 2.0 $) .^{32}$ The related cationic compound $\left[\mathrm{Rh}(\mathrm{nbd})\left\{\mathrm{Ph}_{2} \mathrm{P}\left(\mathrm{CH}_{2}\right)_{2} \mathrm{Py}\right\}\right] \mathrm{BF}_{4}$ (6) is less active than 5 affording a polymer of $M_{\mathrm{W}} 1.66 \mathrm{E}+06$ and a $M_{\mathrm{W}} / M_{\mathrm{n}}$ of 1.69 (entry 7 ). In both cases, the high molecular weight of the obtained PPAs is a consequence of the very low initiation efficiencies of 0.9 and 0.5 , respectively. 
The PPA polymers were isolated as soluble yelloworange solids with a plastic-like appearance. The ${ }^{1} \mathrm{H}$ NMR spectra showed a sharp signal at $\delta 5.82$ ppm (vinyl protons) and six distinctive resonances in the ${ }^{13} \mathrm{C}\left\{{ }^{1} \mathrm{H}\right\}$ NMR spectra in $\mathrm{CDCl}_{3}$ which is indicative of a cis-transoidal configuration with high level of steroregularity. In fact, the cis-content of the polymers determined by NMR was quantified to be superior to $99 \% .{ }^{46,47}$ In addition, the loglog plot of the radius of gyration $\left(r_{\mathrm{g}}\right)$ vs the molar mass (MM) revealed the presence of linear polymer except in the case of the polymer obtained with catalyst 1 for which significant deviations from linear behavior in the high molar mass region were observed which consistent with branching (see Supporting Information). ${ }^{33}$

Table 1. Polymerization of PA catalyzed by compounds 16.

\begin{tabular}{ccccccc}
\hline entry & catalyst & $\begin{array}{c}\mathrm{t} \\
h\end{array}$ & $\begin{array}{c}\text { yield }^{\mathrm{b}} \\
\%\end{array}$ & $M_{\mathrm{w}}{ }^{\mathrm{c}}$ & $M_{\mathrm{w}} / M_{\mathrm{n}}$ & $\begin{array}{c}\mathrm{IE}^{\mathrm{d}} \\
\%\end{array}$ \\
\hline 1 & 1 & 20 & 70 & $2.20 \mathrm{E}+05$ & 1.67 & 6.1 \\
\hline 2 & 2 & 5 & 90 & $2.33 \mathrm{E}+05$ & 1.58 & 4.4 \\
\hline 3 & 3 & - & - & - & - & - \\
\hline 4 & 4 & - & - & - & - & - \\
\hline 5 & $3+i \mathrm{PrNH}_{2}{ }^{\mathrm{e}}$ & 1 & 100 & $3.42 \mathrm{E}+05$ & 1.39 & 4.2 \\
\hline 6 & $4+i \mathrm{PrNH}_{2}{ }^{\mathrm{e}}$ & 0.3 & 100 & $2.02 \mathrm{E}+05^{*}$ & 1.39 & 6.9 \\
\hline 7 & 5 & 2 & 100 & $2.04 \mathrm{E}+06$ & 1.63 & 0.9 \\
\hline 8 & 6 & 5 & 100 & $1.66 \mathrm{E}+06$ & 1.69 & 0.5 \\
\hline
\end{tabular}

${ }^{\text {a }}$ Reaction conditions: THF, $293 \mathrm{~K},[\mathrm{PA}]_{\mathrm{o}}=0.25 \mathrm{M},[\mathrm{PA}]_{\mathrm{o}} /[\mathrm{Rh}]=$ 100. ${ }^{\mathrm{b}}$ Determined by GC (octane as internal standard). ${ }^{\mathrm{c}}$ Determined by SEC-MALS. ${ }^{\mathrm{d}}$ Initiation efficiency, IE $=M_{\mathrm{theor}} / M_{\mathrm{n}} \mathrm{x}$ $100 ; \quad$ where $\quad M_{\text {theor }}=[\mathrm{PA}]_{\mathrm{o}} /[\mathrm{Rh}] \cdot \mathrm{MW}_{\mathrm{PA}} \cdot$ polymer yield. ${ }^{\mathrm{e}}\left[i \mathrm{PrNH}_{2}\right] /[\mathrm{Rh}]=10 . *$ Bimodal molar mass distribution: data for the lower molar mass polymer.

Surprisingly, the cationic complexes $\left[\mathrm{Rh}(\mathrm{cod})\left(\mathrm{Ph}_{2} \mathrm{PPy}\right)\right]\left[\mathrm{BF}_{4}\right] \quad$ (3) and $[\mathrm{Rh}(\mathrm{nbd})(\mu-$ $\left.\left.\mathrm{Ph}_{2} \mathrm{PPy}\right)\right]_{2}\left[\mathrm{BF}_{4}\right]_{2}(4)$ were completely inactive (entries 3 and 4) which contrast with the catalytic performance of 6 . The use of a co-catalysts aims to influence the activity and selectivity of the catalytic reactions and for this reason several bases have been frequently used as co-catalyst in alkyne polymerization reactions. In fact, Masuda et al. have described that polymerization of phenylacetylene with $\mathrm{Rh}(\mathrm{I})$ initiators in the presence of $i \mathrm{PrNH}_{2}$ allows living polymerization affording highly stereoregular polymers with a narrow polydispersity. ${ }^{48}$ In this particular case, the catalytic system $\left[\mathrm{Rh}(\operatorname{cod})\left(\mathrm{Ph}_{2} \mathrm{PPy}\right)\right]\left[\mathrm{BF}_{4}\right]$ (3) $/ i \mathrm{PrNH}_{2}\left(i \mathrm{PrNH}_{2} / \mathrm{Rh}\right.$ ratio of 10$)$ efficiently polymerized PA in $1 \mathrm{~h}$ to give a polymer of $M_{\mathrm{w}} 3.42 \mathrm{E}+05$ and a polydispersity of 1.39 (entry 5). As it could be expected, the catalytic system $\left[\mathrm{Rh}(\mathrm{nbd})\left(\mu-\mathrm{Ph}_{2} \mathrm{PPy}\right)\right]_{2}\left[\mathrm{BF}_{4}\right]_{2} \quad(4) / \mathrm{PrNH}_{2}$ $\left(i \mathrm{PrNH}_{2} / \mathrm{Rh}\right.$ ratio of 10$)$ is even more active with complete
PA conversion in 20 min under the same conditions. The obtained PPA has a bimodal molar mass distribution with a main fraction of $M_{\mathrm{w}}$ of $2.02 \mathrm{E}+05$ and the same polydispersity (entry 6).

In view of these results and in order to identify the active species under the reaction conditions, the reactivity of compounds 3 and 4 with isopropylamine and phenylacetylene has been studied separately.

Reactivity of complexes $\left[\mathrm{Rh}(\text { diene })\left(\mathrm{Ph}_{\mathbf{2}} \mathrm{PPy}\right)\right]_{\mathbf{n}}{ }^{\mathrm{n}+}$ (diene $=\operatorname{cod}, \mathbf{n}=1 ; \mathbf{n b d}, \mathbf{n}=\mathbf{2}$ ) with isopropylamine. The addition of 2 molar equiv of $i \mathrm{PrNH}_{2}$ to a solution of complex $\left[\mathrm{Rh}(\mathrm{nbd})\left(\mu-\mathrm{Ph}_{2} \mathrm{PPy}\right)\right]_{2}\left[\mathrm{BF}_{4}\right]_{2}(4)$ in $\mathrm{CH}_{2} \mathrm{Cl}_{2}$ at 273 $\mathrm{K}$ resulted in the formation of a yellow solution of the mononuclear complex $\left[\mathrm{Rh}(\mathrm{nbd})\left(\mathrm{PrNH}_{2}\right)\left(\mathrm{Ph}_{2} \mathrm{PPy}\right)\right]\left[\mathrm{BF}_{4}\right]$ (7) which was isolated as a yellow solid in $67 \%$ yield (Scheme 1). The spectroscopic data for 7 in $\mathrm{CD}_{2} \mathrm{Cl}_{2}$ at $195 \mathrm{~K}$ are in agreement with a square-planar structure of $C_{\mathrm{s}}$ symmetry resulting from the bridge splitting reaction by $i \mathrm{PrNH}_{2}$. The isopropylamine ligand in 7 shows three broad resonances in the ${ }^{1} \mathrm{H}$ NMR spectrum at $\delta 4.32(\mathrm{br}$, $\left.\mathrm{NH}_{2}\right), 2.51$ (br, $\left.\mathrm{CH}\right)$ and $1.10 \mathrm{ppm}\left(\mathrm{d}, \mathrm{CH}_{3}\right)$ and two in the ${ }^{13} \mathrm{C}\left\{{ }^{1} \mathrm{H}\right\}$ NMR spectrum at 46.o $(\mathrm{CH})$ and $24.9 \mathrm{ppm}\left(\mathrm{CH}_{3}\right)$. Similarly, compound $\left[\mathrm{Rh}(\operatorname{cod})\left(\mathrm{Ph}_{2} \mathrm{PPy}\right)\right]\left[\mathrm{BF}_{4}\right]$ (3) reacts with $i \mathrm{PrNH}_{2}$ in $\mathrm{CH}_{2} \mathrm{Cl}_{2}$ to give the a yellow solution of complex $\left[\mathrm{Rh}(\mathrm{cod})\left(\mathrm{PrNH}_{2}\right)\left(\mathrm{Ph}_{2} \mathrm{PPy}\right)\right]^{+}(\mathbf{8})$ as a result of the ring opening of the metallacycle (Scheme 1 ). Compound 8 could not be isolated as a solid and has been characterized in situ by NMR. The ${ }^{31} \mathrm{P}\left\{{ }^{1} \mathrm{H}\right\}$ NMR at $195 \mathrm{~K}$ shows a doublet resonance at $\delta 21.60 \mathrm{ppm}\left(J_{\mathrm{P}-\mathrm{Rh}}=155.4 \mathrm{~Hz}\right)$ downfield shifted compared to that of the parent compound 3 $(\delta-40.03 \mathrm{ppm})$, which is consistent with a change in the coordination mode of the $\mathrm{Ph}_{2} \mathrm{PPy}$ ligand from $\kappa^{2} P, N$ to $\kappa^{1} P$. Compound 7 also exhibits a doublet at $\delta 26.65 \mathrm{ppm}$ although with a larger $J_{\mathrm{P}-\mathrm{Rh}}$ coupling constant of $172.6 \mathrm{~Hz}$, due to the influence of the higher $\pi$-acceptor character of the nbd diolefin.

Scheme 1. Synthesis of complexes $\left[\mathrm{Rh}(\right.$ diene $)\left(\mathrm{iPrNH}_{2}\right)_{\mathrm{n}}\left(\mathrm{Ph}_{2} \mathrm{PPy}\right)\left[\mathrm{BF}_{4}\right]$ (diene $=$ cod, nbd).

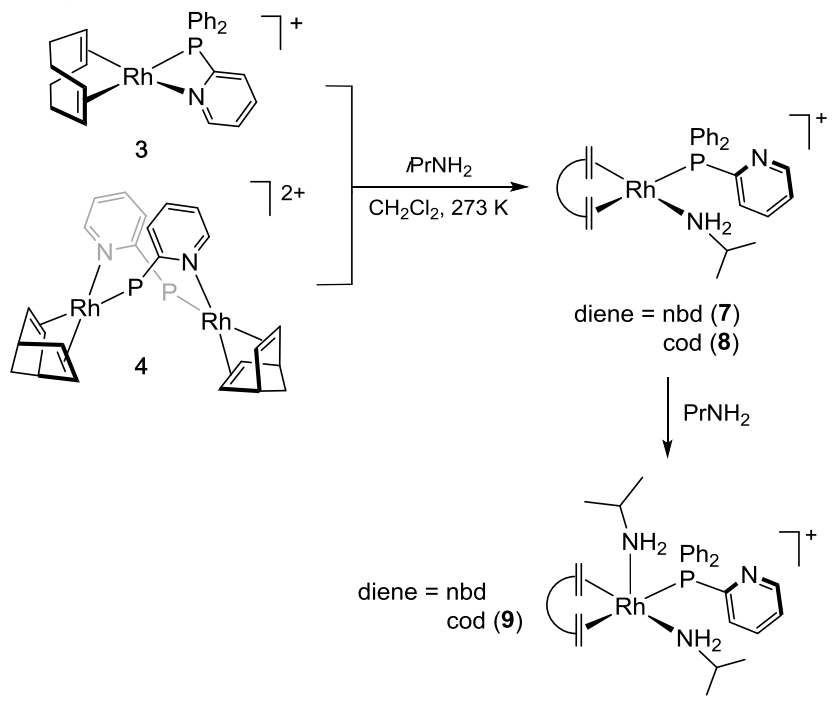


Both compounds react further with $i \mathrm{PrNH}_{2}$ to give the pentacoordinated species $\left[\mathrm{Rh}(\text { diene })\left(\mathrm{PPNH}_{2}\right)_{2}\left(\mathrm{Ph}_{2} \mathrm{PPy}\right)\right]^{+}$ which exhibited a fluxional behavior. The ${ }^{31} \mathrm{P}\left\{{ }^{1} \mathrm{H}\right\}$ NMR of a solution of compound 3 in $\mathrm{CD}_{2} \mathrm{Cl}_{2}$ after addition of 2.5 molar equiv of $i \mathrm{PrNH}_{2}$ at $195 \mathrm{~K}$ showed a broad signal centered at $\delta 22.48 \mathrm{ppm}$ and a set of new resonances for $\mathrm{Ph}_{2} \mathrm{PPy}$, cod and coordinated $i \mathrm{PrNH}_{2}$ ligands in the ${ }^{1} \mathrm{H}-{ }^{1} \mathrm{H}$ COSY NMR (THF- $\left.\mathrm{d}^{8}, 243 \mathrm{~K}\right)$ which were ascribed to compound $\left[\mathrm{Rh}(\text { diene })\left(\mathrm{PrNH}_{2}\right)_{2}\left(\mathrm{Ph}_{2} \mathrm{PPy}\right)\right]^{+}$(9) (see Supporting Information).

Interestingly, compound $\left[\mathrm{Rh}(\mathrm{nbd})\left(\mathrm{PPrNH}_{2}\right)\left(\mathrm{Ph}_{2} \mathrm{PPy}\right)\right]\left[\mathrm{BF}_{4}\right]$ (7) quantitatively polymerizes PA under our standard conditions $\left(293 \mathrm{~K},[\mathrm{PA}]_{\mathrm{o}}=\right.$ $0.25 \mathrm{M},[\mathrm{PA}]_{\mathrm{o}} /[7]=100$ ) in $1.5 \mathrm{~h}$ affording a PPA with an unimodal molar mass distribution of $M_{\mathrm{w}}=3.06 \mathrm{E}+05$ and a polydispersity index of 1.45 . The molecular catalyst 7 is less active than the catalytic system $4 / i \mathrm{PrNH}_{2}$ (1:20) but provides a PPA of higher molar mass with a moderate polydispersity index.

Reactivity of complexes $\left[\mathrm{Rh}(\text { diene })\left(\mathrm{Ph}_{\mathbf{2}} \mathbf{P P y}\right)\right]_{\mathbf{n}^{\mathrm{n}}}{ }^{\mathrm{n}}$ (diene $=\operatorname{cod}, \mathbf{n}=1 ; \mathbf{n b d}, \mathbf{n}=2$ ) with phenylacetylene derivatives. Reaction of $\left[\mathrm{Rh}(\operatorname{cod})\left(\mathrm{Ph}_{2} \mathrm{PPy}\right)\right]\left[\mathrm{BF}_{4}\right]$ (3) with phenylacetylene or 4-tert-butylphenylacetylene $\left(\begin{array}{l}1 \\ :\end{array}\right.$ molar ratio) in THF at RT gave the dinuclear compounds $\left[\mathrm{Rh}_{2}(\operatorname{cod})_{2}\left(\mu-\mathrm{Ph}_{2} \mathrm{PPy}\right)(\mu-\mathrm{C} \equiv \mathrm{C}-\mathrm{R})\right]\left[\mathrm{BF}_{4}\right]\left(\mathrm{R}=\mathrm{Ph}, \mathbf{1 0} ; \mathrm{C}_{6} \mathrm{H}_{4}-\right.$ $t \mathrm{Bu}, 11)$. The molecular framework in these complexes is supported by a $\mathrm{Ph}_{2} \mathrm{PPy}$ bridging ligand $1 \kappa P, 2 \kappa N$ coordinated and an alkynyl ligand coordinated in a $\mu-\eta^{1}: \eta^{2}$ fashion, bonded to both rhodium atoms through $\sigma\left(\eta^{1}\right)$ and $\pi$ $\left(\eta^{2}\right)$ coordination. $^{49}$ In the same way, compound $\left[\mathrm{Rh}_{2}(\mathrm{nbd})\left(\mu-\mathrm{Ph}_{2} \mathrm{PPy}\right)\right]_{2}\left[\mathrm{BF}_{4}\right]_{2}(4)$ reacts with $\mathrm{PhC} \equiv \mathrm{CH}(1: 4$ molar ratio) under the same conditions to give the related compound $\left[\mathrm{Rh}_{2}(\mathrm{nbd})_{2}\left(\mu-\mathrm{Ph}_{2} \mathrm{PPy}\right)(\mu-\mathrm{C} \equiv \mathrm{CPh})\right]\left[\mathrm{BF}_{4}\right] \quad$ (12) (Scheme 2).

Scheme 2. Synthesis of complexes $\left[R h_{2}(\text { diene })_{2}(\mu-\right.$ $\left.\left.\mathrm{Ph}_{2} \mathrm{PPy}\right)(\boldsymbol{\mu}-\mathrm{C} \equiv \mathrm{C}-\mathrm{R})\right]\left[\mathrm{BF}_{4}\right]$ (diene $=\operatorname{cod}, \mathbf{n b d} ; \mathbf{R}=\mathbf{H}$, $\left.\mathrm{C}_{6} \mathrm{H}_{4}-t \mathrm{Bu}\right)$.
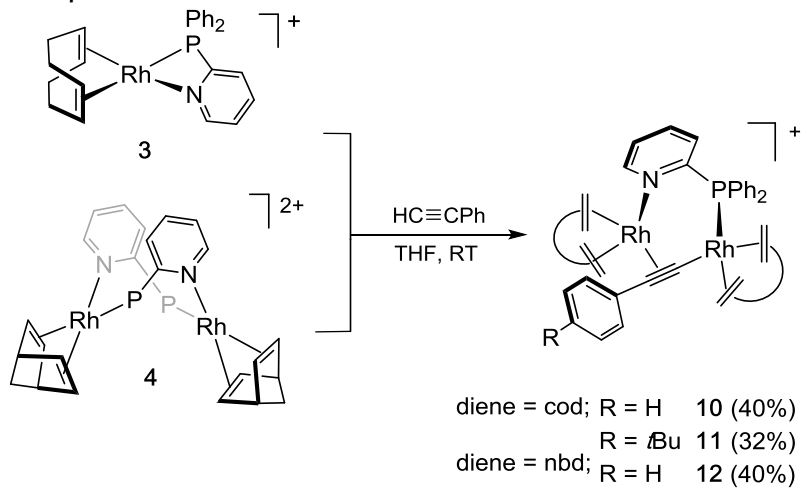

In general, these reactions are not clean and recrystallization of the crude compounds is necessary to separate poorly soluble solids, which results in low isolated yields $(\approx 40 \%)$. The compounds were obtained as relatively airstable red microcrystalline solids and have been completely characterized by elemental analysis, NMR spectroscopy and mass spectrometry. The crystal structure of
12 was determined by means of single crystal X-ray diffraction. A view of the dinuclear cation $\left[\mathrm{Rh}_{2}(\mathrm{nbd})_{2}\left(1 \kappa P, 2 \kappa N-\mathrm{Ph}_{2} \mathrm{PPy}\right)\left(1 \kappa C, 2 \kappa^{2} C, C^{\prime}-\mathrm{C} \equiv \mathrm{CPh}\right)\right]^{+} \quad$ is given in Figure 2 along with selected bond lengths and angles. Both rhodium centers feature a distorted square planar environment with the bidentate nbd ligand at two coordination sites and the remaining donor atoms at the remaining cis positions [C(19)- $\mathrm{Rh}(1)-\mathrm{P}$ 97.80(12)o; $\mathrm{N}(2)$ $\mathrm{Rh}(2)-\mathrm{CTo} 5$ 88.66(9), CTo5, centroid of C(19) and C(20)].

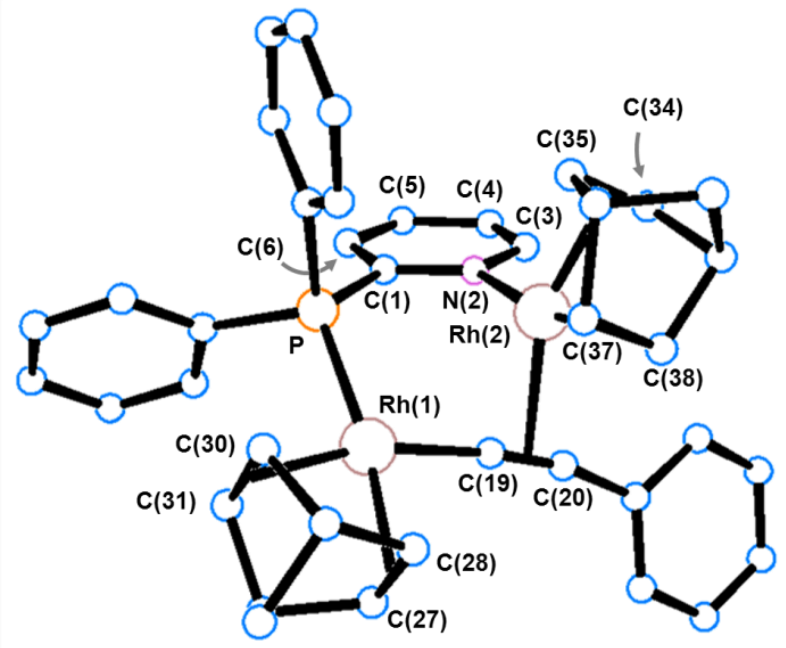

Figure 2. View of the crystal structure of $\left[\mathrm{Rh}_{2}(\mathrm{nbd})_{2}\left(1 \kappa P, 2 \kappa N-\mathrm{Ph}_{2} \mathrm{PPy}\right)\left(1 \kappa C, 2 \kappa^{2} C, C^{\prime}-\mathrm{C} \equiv \mathrm{CPh}\right)\right]^{+}$in 12. Hydrogen atoms are omitted for clarity. Selected bond lengths ( $\AA$ ) and angles (o) are $\mathrm{Rh}(1)$-CTo1 2.0911(4); C(27)C(28) 1.374(6); Rh(1)-CTo2 2.0783(4), C(30)-C(31) 1.383(6), C(19)-Rh(1) 1.990(4), P-Rh(1) 2.2818(11), CTo2-Rh(1)-CTo1 70.280(17), C(19)-Rh(1)-P 97.8o(12), Rh(2)-CTo3 1.9943(4), $\mathrm{Rh}(2)-\mathrm{CTO} 4 \quad 2.0301(4), \quad \mathrm{Rh}(2)-\mathrm{CTO} 5$ 2.2502(4), N(2)-Rh(2) $2.090(3), C(34)-C(35) 1.407(6), C(37)-C(38) 1.385(6), C(19)-$ $\mathrm{C}(20) 1.232(6), \mathrm{C}(19)-\mathrm{Rh}(2)$ 2.186(4), C(20)-Rh(2) 2.471(4), $\mathrm{Rh}(1) \cdots \mathrm{Rh}(2) \quad 3.1361(7), \mathrm{CTo}-\mathrm{Rh}(2)-\mathrm{CTo} 4$ 71.537(14), N(2)Rh(2)-CTo5 88.66(9), Rh(1)-P-C(1)-N(2) -45.7(3). Pitch ( $\square$ ) and yaw $(\square)$ angles of the pyridinyl moiety are $\square$ 2.6 $6^{\circ}, \square$ 0.4 ${ }^{\circ}$. CTo1, centroid of $\mathrm{C}(27)$ and $\mathrm{C}(28)$; CTo2, centroid of $\mathrm{C}(30)$ and $\mathrm{C}(31)$; CTo3, centroid of $\mathrm{C}(34)$ and $\mathrm{C}(35)$; CTo4, centroid of $C(37)$ and $C(38)$; $C$ To5, centroid of $C(19)$ and $C(20)$.

Notably the intermetallic distance $[\mathrm{Rh}(1) \cdots \mathrm{Rh}(2)$ 3.1361(7)] rules out any metal-metal interaction [rhodium covalent radius $1.42(7) \AA^{50}$ ] and the dinuclear frame is exclusively supported by the $1 \kappa P, 2 \kappa N-\mathrm{Ph}_{2} \mathrm{PPy}$ and the $1 \kappa C, 2 \kappa^{2} C, C^{\prime}-\mathrm{C} \equiv \mathrm{CPh}$ ligands. To the best of our knowledge, only very few dinuclear rhodium(I) complexes featuring a $1 \kappa P, 2 \kappa N$ coordination mode of $\mathrm{Ph}_{2} \mathrm{PPy}$ have been structurally characterized so far, all of them containing a $\mu-\mathrm{CO}$ ligand and featuring intermetallic distances indicative of a metal-metal interaction $(<2.70 \AA) .{ }^{51,52,53,54}$

On the other hand, the $1 \kappa C, 2 \kappa C, C^{\prime}$ coordination mode of acetylides is quite common, and as for rhodium(I) dinuclear complexes, several derivatives containing the $\mathrm{Rh}_{2}\left(1 \kappa C, 2 \kappa^{2} C, C^{\prime}-C \equiv C R\right)$ motif have already been reported 
nicely featuring rhodium-carbon bond lengths similar to those observed in 12. ${ }^{55,56,57,58,59,60,61,62}$

Finally the coordination sphere at $\mathrm{Rh}(2)$ is worth a mention. The pitch ( $\square$ o.4) and yaw ( $\square$ 2.6) angles of the pyridine moiety indicate an almost ideal arrangement of the heterocyclic ring with respect to the $\mathrm{Rh}(2)-\mathrm{N}(2)$ bond. In addition the coordinated triple bond is almost perpendicular to the coordination plane of $\mathrm{Rh}(2)$ [C(20)-C(19)$\mathrm{Rh}(2)-\mathrm{N}(2)$ 92.74(28)o] and, similarly to related acetylido rhodium dinuclear derivatives, different rhodium-carbon bonds, namely C(19)-Rh(2) 2.186(4) Å, C(20)-Rh(2) 2.471(4) Å, are observed.

The dinuclear formulation of the compounds was confirmed in the MALDI-Tof mass spectra where the corresponding molecular ions with the expected isotopic distribution were observed. In addition, the molar conductivity of acetone solutions of the complexes 115-122 $\Omega^{-}$ ${ }^{1} \mathrm{~cm}^{2} \mathrm{~mol}^{-1}\left(5.0 \times 10^{-4} \mathrm{M}\right)$ are in the expected range for $1: 1$ electrolytes. The ${ }^{31} \mathrm{P}\left\{{ }^{1} \mathrm{H}\right\}$ NMR spectrum of the complexes $\left(\mathrm{CD}_{2} \mathrm{Cl}_{2}, 298 \mathrm{~K}\right)$ shows a doublet resonance at $\delta \approx 19-24$ ppm with $J_{\mathrm{P}-\mathrm{Rh}}$ coupling constants of 148-154 Hz characteristic of rhodium (I) species. On the other hand, the ${ }^{1} \mathrm{H}$ NMR spectra are in agreement with the unsymmetrical structure found in the solid state. The unequivocal assignment of the resonances in the ${ }^{1} \mathrm{H}$ and ${ }^{13} \mathrm{C}\left\{{ }^{1} \mathrm{H}\right\}$ NMR spectra has been achieved by combination of ${ }^{1} \mathrm{H}-{ }^{1} \mathrm{H}$ COSY, ${ }^{1} \mathrm{H}-{ }^{13} \mathrm{C}$ HSQC and ${ }^{13} \mathrm{C}\left\{{ }^{1} \mathrm{H}\right\}$-apt experiments (see Supporting Information).

As an example, the ${ }^{1} \mathrm{H}$ NMR spectrum of 10 shows eight well defined resonances for the $=\mathrm{CH}$ protons of the cod ligands that can be grouped into pairs of protons attached to the same double bond with the help of the ${ }^{1} \mathrm{H}-{ }^{1} \mathrm{H}$ COSY spectrum. The ${ }^{1} \mathrm{H}^{13} \mathrm{C}$ HSQC allows for the assignment of the corresponding carbon resonances in the ${ }^{13} \mathrm{C}\left\{{ }^{1} \mathrm{H}\right\}$ NMR spectrum that shows six doublets resonances with $J_{\mathrm{C}-\mathrm{Rh}}$ of 7-14 Hz, a triplet $\left(J_{\mathrm{C}-\mathrm{Rh}} \approx J_{\mathrm{C}-\mathrm{P}}=7.9 \mathrm{~Hz}\right)$ and a doublet of doublets $\left(J_{\mathrm{C}-\mathrm{Rh}}=\mathbf{1 4 . 2}\right.$ and $\left.J_{\mathrm{C}-\mathrm{P}}=7.0 \mathrm{~Hz}\right)$, the latter two corresponding to the $\mathrm{C}=\mathrm{C}$ bond trans to the $\mathrm{P}$ donor atom. The spectrum also shows a broad resonance at $\delta 103.5$ ppm assigned to the $\alpha$-carbon atom of the alkynyl ligand ( $\mathrm{Rh}-\mathrm{C} \equiv \mathrm{CPh}$ ) although the $\beta$-carbon atom was not observed. For comparative purposes, the alkynyl ligand $\mu$ $\eta^{1}(\mathrm{Ir}): \eta^{2}(\mathrm{Rh})$ coordinated in compound $\left[\operatorname{RhIr}(\mathrm{CO})_{2}(\mu-\right.$ $\left.\mathrm{C} \equiv \mathrm{CPh})(\mathrm{dppm})_{2}\right]^{+}$shows two multiplets at $\delta 107.9$ ( $\alpha$ carbon) and 106.0 ppm ( $\beta$ carbon). ${ }^{63}$ The assignment of the rest of the protons was possible through the ${ }^{1} \mathrm{H}-{ }^{1} \mathrm{H}$ NOESY spectrum (see Supporting Information). Thus, the proximity cross-peaks allow for the identification of the pair of $=\mathrm{CH}$ protons of each cod ligand directed towards the pocket of the molecular framework of different olefins (2.59 $\AA$ in the structure of $\mathbf{1 2}$ ). In addition, the proximity cross-peaks involving the $\mathrm{H}-6$ proton of the pyridine ring and the protons of the phenyls of the $\mathrm{PPh}_{2}$ fragment allows the unambiguous assignment of the protons in the $\mathrm{CH}=\mathrm{CH}$ bonds nearest to the $\mathrm{Ph}_{2} \mathrm{PPy}$ bridging ligand.
The ${ }^{1} \mathrm{H}-{ }^{1} \mathrm{H}$ NOESY spectrum also shows exchange crosspeaks between the protons of each one of the $\mathrm{CH}=\mathrm{CH}$ bonds $\left(\mathrm{H}_{1}-\mathrm{H}_{4}, \mathrm{H}_{2}-\mathrm{H}_{7}, \mathrm{H}_{3}-\mathrm{H}_{5}\right.$ and $\left.\mathrm{H}_{6}-\mathrm{H}_{8}\right)$ and simultaneously, between the protons of the cod ligand on the rhodium atom coordinated to pyridine, $\mathrm{H}_{3}-\mathrm{H}_{6}$ and $\mathrm{H}_{5}-$ H8 (see Scheme 9 in the Experimental Section). This exchange pattern is the result of a dynamic process that involves: i) uncoordination of the $\pi$-alkynyl ligand, ii) rotation of the square-planar fragment around the $\mathrm{P}-\mathrm{Rh}$ bond, and iii) re-coordination of the $\sigma$-alkynyl ligand to rhodium by the opposite side of the molecular framework. This process results in the interconversion of the two enantiomers of the compound and explains the exchange process observed between the protons of the $\mathrm{CH}=\mathrm{CH}$ bonds. In stepe ii, the rhodium center coordinated to the pyridine fragment of the bridging ligand remains tri-coordinated, which allows the rotation of this $\mathrm{Rh}$ (cod) fragment, and therefore explains the exchange process between protons $\mathrm{H}_{3}-\mathrm{H}_{6}$ and $\mathrm{H}_{5}-\mathrm{H}_{8}$ of that diolefin (see Supporting Information).

The spectroscopic data for compound $\left[\mathrm{Rh}_{2}(\operatorname{cod})_{2}(\mu-\right.$ $\left.\left.\mathrm{Ph}_{2} \mathrm{PPy}\right)\left(\mu-\mathrm{C} \equiv \mathrm{C}-\mathrm{C}_{6} \mathrm{H}_{4}-t \mathrm{Bu}\right)\right]\left[\mathrm{BF}_{4}\right]$ (11) are comparable to those of 10 and then, both compounds should be isostructural. However, the ${ }^{1} \mathrm{H}-{ }^{1} \mathrm{H}$ NOESY spectrum only show exchange cross-peaks between the protons of the cod ligand on the rhodium atom coordinated to pyridine $\left(\mathrm{H}_{3}-\right.$ $\mathrm{H} 6$ and $\mathrm{H}_{5}-\mathrm{H} 8$ ) but no between the protons of the individual $\mathrm{CH}=\mathrm{CH}$ bonds which suggests hindered rotation about the P-Rh bond after decoordination of the $\pi$ alkynyl ligand likely because of the bulky $t \mathrm{Bu}$ group.

Unexpectedly, when the reaction of $\left[\mathrm{Rh}(\operatorname{cod})\left(\mathrm{Ph}_{2} \mathrm{PPy}\right)\right]\left[\mathrm{BF}_{4}\right]$ (3) with phenylacetylene was carried out in $\mathrm{CH}_{2} \mathrm{Cl}_{2}$ instead of THF, in addition to 10, a second product was obtained as a major species (7:3 ratio). This new specie\$ has been characterized in solution by $\mathrm{NMR}$ as $\left[(\mathrm{cod}) \mathrm{Rh}\left(\mathrm{Ph}_{2} \mathrm{PC}_{5} \mathrm{H}_{4} \mathrm{~N}-\mathrm{C}=\mathrm{CHPh}\right)\right]\left[\mathrm{BF}_{4}\right] \quad$ (13) which features a five-membered rhodaheterocycle resulting from the coupling of an alkyne molecule and the pyridine fragment of the $\mathrm{Ph}_{2} \mathrm{PPy}$ ligand (Scheme 3 ).

Scheme 3. Reaction of formation of
$\left[(\operatorname{cod}) R h\left(\mathrm{Ph}_{2} \mathrm{PC}_{5} \mathrm{H}_{4} \mathrm{~N}-\mathrm{C}=\mathrm{CHPh}\right)\right]\left[\mathrm{BF}_{4}\right](13)$.




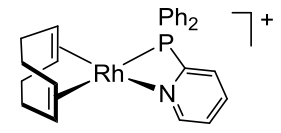

3

$\mathrm{HC} \equiv \mathrm{CPh}$ $\mathrm{CH}_{2} \mathrm{Cl}_{2}$

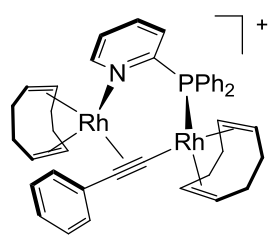

10

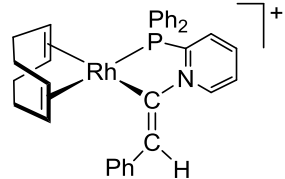

13
$3: 7$ ratio

Unfortunately, compound $\mathbf{1 3}$ could not be isolated from the reaction mixture and consequently was characterized in solution. The ${ }^{13} \mathrm{C}\left\{{ }^{1} \mathrm{H}\right\}$-apt spectrum recorded in $\mathrm{CD}_{2} \mathrm{Cl}_{2}$ at $213 \mathrm{~K}$ shows a doublet of doublets at $\delta 177.60 \mathrm{ppm}\left(J_{\mathrm{C}-\mathrm{Rh}}\right.$ $=43.0$ and $J_{\mathrm{C}-\mathrm{P}}=14.6 \mathrm{~Hz}$ ) that was assigned to the quaternary carbon of the alkenyl fragment in the metallacycle. ${ }^{64}$
On the other hand, this resonance exhibits a cross peak in the ${ }^{1} \mathrm{H}-{ }^{13} \mathrm{C}-\mathrm{HMBC}$ spectrum with the resonance at $\delta 6.96$ ppm of the ${ }^{1} \mathrm{H}$ NMR spectrum, which in turn correlates with the $\mathrm{CH}$ at $\delta 136.1 \mathrm{ppm}$ in the ${ }^{1} \mathrm{H}-{ }^{13} \mathrm{C}$-HSQC NMR spectrum, which is consistent with the presence of the alkenyl fragment. Besides, the ${ }^{1} \mathrm{H}-{ }^{15} \mathrm{~N}$ HMQC NMR spectrum shows a long range coupling of the $\mathrm{Rh}-\mathrm{C}=\mathrm{CHPh}$ resonance at $\delta 6.96 \mathrm{ppm}$ and the nitrogen of the pyridine fragment which was observed at 263.2 ppm thereby confirming the presence of the rhodaheterocycle in 13 (see Supporting Information).

Mechanism for the

formation of $\left[(\operatorname{cod}) \mathbf{R h}\left(\mathrm{Ph}_{2} \mathrm{PC}_{5} \mathrm{H}_{4} \mathbf{N}-\mathrm{C}=\mathrm{CHPh}\right)\right]\left[\mathrm{BF}_{4}\right](13)$. A possible route for the formation of $\mathbf{1 3}$ that involves a Rh-vinylidene intermediate is shown in Scheme 4. Reaction of 3 with phenylacetylene should result in the opening of fourmembered metallacycle and formation of a $\pi$-alkyne complex (A). Deprotonation of the coordinated phenylacetylene assisted by the pyridine fragment of the 2(diphenylphosphino)pyridine ligand might result in a alkynyl complex (C) which after a second prototropic redistribution would carry the $\mathrm{N}-\mathrm{H}$ hydrogen to the $\mathrm{C}_{\beta}$ atom of the alkynyl ligand to form a vinylidene interme-

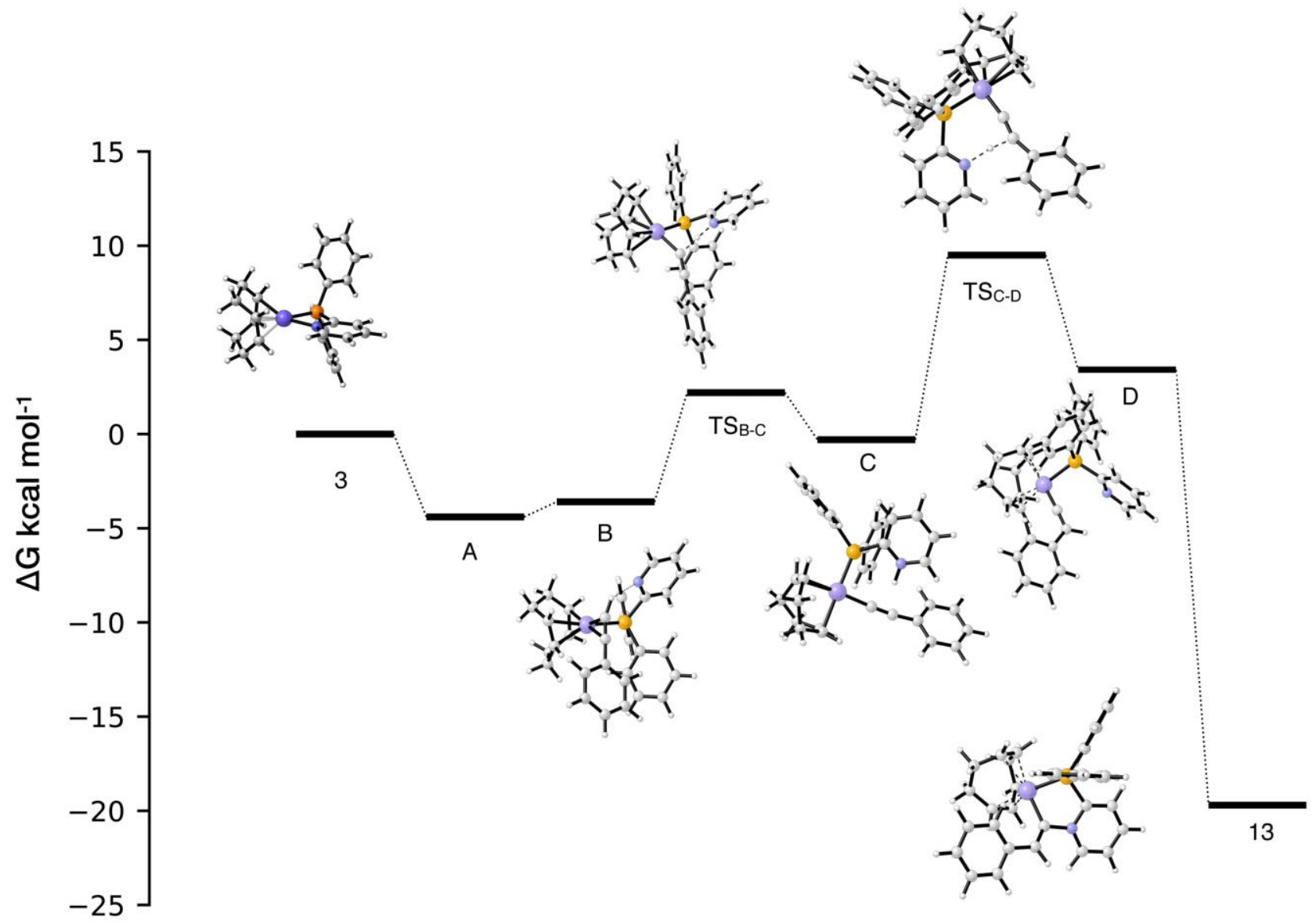

Figure 3. Energy profile calculated by DFT methods for the formation of compound $\mathbf{1 3}$ through an intramolecular alkynevinylidene transformation assisted by the 2- (diphenylphosphino)pyridine ligand. 
diate (D). This intermediate can be also formed directly by an alkyne/vinylidene tautomerization either by 1,2 displacement of the hydrogen atom, or by oxidative addition to generate an intermediate rhodium alkynyl hydride species and subsequent migration 1,3 of the hydride ligand to the $C_{\text {口 }}$ of the alkynyl ligand. ${ }^{65,66,67}$ Finally, the nucleophilic attack of the $\mathrm{N}$ atom of the pyridine fragment to the electrophilic $C_{\alpha}$ carbon atom of the vinylidene intermediate should lead to the formation of the fivemembered rhodaheterocycle of $\mathbf{1 3}$.

The mechanism for this transformation has been studied theoretically by DFT methods. The formation of 13 through an intramolecular alkyne-vinylidene transformation assisted by the 2-(diphenylphosphino)pyridine ligand was established as the more energy feasible reaction pathway (Figure 3). Coordination of phenylacetylene to 3 to form A is a favorable process by $-4.4 \mathrm{kcal} \mathrm{mol}^{-1}$. Rotation of the pyridine substituent gives an intermediate B which shows a hydrogen bond between the $\equiv \mathrm{CH}$ of phenylacetylene and the pyridine fragment of the phosphine ligand. It is slightly unstable relative to $\mathbf{A}$ by 0.8 $\mathrm{kcal} \mathrm{mol}^{-1}$. From B a TS $\mathrm{B}_{\text {-C }}$ is easily reached $(+5.7 \mathrm{kcal} \mathrm{mol-}$ 1) which gives intermediate $\mathbf{C}$ featuring a 2(diphenylphosphino)pyridinium ligand. The process is 3.3 $\mathrm{kcal} \mathrm{mol}^{-1}$ endoergic relative to $\mathbf{B}$. Formation of a prototropic tautomer $\mathbf{D}$ through $\mathrm{TS}_{\mathrm{C}-\mathrm{D}}$ requires only $8.7 \mathrm{kcal}$ $\mathrm{mol}^{-1}$ (Figure 3). This intermediate is destabilized $3.7 \mathrm{kcal}$ $\mathrm{mol}^{-1}$ with respect to intermediate $\mathbf{C}$. Intermediate $\mathbf{D}$ shows a pyridil substituent in an orientation which has the $\mathrm{N}$ atom slightly tilted away from from de $\mathrm{C}_{\beta}$ atom of the vinylidene ligand. Eventually, a five-membered rhodaheterocycle is formed resulting compound $\mathbf{1 3}$ which is stabilized $-19.7 \mathrm{kcal} \mathrm{mol}^{-1}$ with respect to the starting compound 3. No transition state has been found in the transient form $\mathbf{D}$ to 13, this suggests that the barrier must be shallow and limited to the favourable rotation of the pyridine ligand and the step is virtually barrierless, as found in similar processes. ${ }^{68}$

The formation of a related ruthenaheterocycle via a vinylidene intermediate has been reported by Grotjahn et $a l$. in the reaction of the compound $\left[\mathrm{CpRu}\left(\mathrm{Ph}_{2} \mathrm{PPy}\right)_{2}\right]^{+}$ with phenylacetylene. ${ }^{69}$ Likewise, Carmona et al. have studied the reactivity of iridium pyridylidene complexes with ethylene, propylene and acetylene to produce new pyridylidene-based iridacyclic structures resulting from the nucleophilic attack of the pyridylene nitrogen atom to the $\mathrm{C}_{\alpha}$ carbon atom of a vinylidene intermediate. ${ }^{68}$ However, the migration of the pyridylene ligand to the carbon atom $\mathrm{C}_{\alpha}$ of the vinylidene ligand assisted by the coordination of pyridine was observed in related trispirazolylmethane osmium complexes which gives rise to a fourmembered osmacycle. ${ }^{70}$

Mechanism for the formation of dinuclear complexes $\left[\mathrm{Rh}_{\mathbf{2}}(\text { diene })_{\mathbf{2}}\left(\boldsymbol{\mu}-\mathrm{Ph}_{\mathbf{2}} \mathbf{P P y}\right)(\boldsymbol{\mu}-\mathrm{C} \equiv \mathrm{C}-\mathrm{R})\right]\left[\mathrm{BF}_{\mathbf{4}}\right]$. The formation of dinuclear complexes $\left[\mathrm{Rh}_{2}(\text { diene })_{2}(\mu-\right.$ $\left.\left.\mathrm{Ph}_{2} \mathrm{PPy}\right)(\mu-\mathrm{C} \equiv \mathrm{C}-\mathrm{R})\right]\left[\mathrm{BF}_{4}\right] \quad$ (10-12) from compounds $\left[\mathrm{Rh}(\mathrm{cod})\left(\mathrm{Ph}_{2} \mathrm{PPy}\right)\right]\left[\mathrm{BF}_{4}\right]$ (3) y $\left[\mathrm{Rh}(\mathrm{nbd})\left(\mu-\mathrm{Ph}_{2} \mathrm{PPy}\right)\right]_{2}\left[\mathrm{BF}_{4}\right]_{2}$
(4) formally involves the loss of a $\mathrm{Ph}_{2} \mathrm{PPy}$ ligand. In order to rationalize the formation of this type of compounds the reaction of 3 with $\mathrm{PA}$ was investigated in detail. The ${ }^{31} \mathrm{P}\left\{{ }^{1} \mathrm{H}\right\}$ NMR of the reaction of 3 with $\mathrm{PhC} \equiv \mathrm{CH}(1: 2.5)$ in THF- $d_{8}$ at $298 \mathrm{~K}$ showed exclusively a doublet resonance corresponding to the dinuclear compound 10. However, the spectrum recorded at $193 \mathrm{~K}$ also showed a minor species that displays three broad resonances centered at $\delta$ 53.75, 34.81 and $30.03 \mathrm{ppm}$ which correspond to the cationic compound $\left[\mathrm{Rh}\left(\mathrm{Ph}_{2} \mathrm{PPy}\right)_{3}\right]^{+}$(see Supporting Information). In agreement with the formation of this species, the ${ }^{1} \mathrm{H}$ NMR spectrum showed the presence of of free cod ( $\delta 5.57$ and $2.40 \mathrm{ppm})$.

Reaction of $\left[\mathrm{Rh}(\mathrm{cod})\left(\mathrm{Ph}_{2} \mathrm{PPy}\right)\right]^{+}$with 1 molar equiv of $\mathrm{Ph}_{2} \mathrm{PPy}$ affords the known cation species $\left[\mathrm{Rh}(\operatorname{cod})\left(\mathrm{Ph}_{2} \mathrm{PPy}\right)_{2}\right]^{+} .^{71}$ However, reaction with 2 molar equiv of $\mathrm{Ph}_{2} \mathrm{PPy}$ gave the cation $\left[\mathrm{Rh}\left(\mathrm{Ph}_{2} \mathrm{PPy}\right)_{3}\right]^{+}$which was isolated as the tetrafluoroborate salt in $57 \%$ yield. The ${ }^{31} \mathrm{P}\left\{{ }^{1} \mathrm{H}\right\}$ NMR of $\left[\mathrm{Rh}\left(\mathrm{Ph}_{2} \mathrm{PPy}\right)_{3}\right]\left[\mathrm{BF}_{4}\right](\mathbf{1 4})$ at room temperature in acetone- $d_{6}$ is silent, but at $200 \mathrm{~K}$ three welldefined resonances appeared at $\delta 55.34(\mathrm{~d}, \mathrm{br}), 32.63$ (ddd) and -28.74 (ddd) ppm (see Supporting Information). The high-field resonance corresponds to the $\kappa^{2} P, N$ coordinated phosphine whereas the broad low-field signal corresponds to the phosphine ligand trans to the pyridine fragment of the chelating phosphine.

Single crystals of $\mathbf{1 4}$ suitable for an X-ray diffraction analysis were obtained. A view of the crystal structure of the cation $\left[\mathrm{Rh}\left(\kappa^{2} N, P-\mathrm{Ph}_{2} \mathrm{PPy}\right)\left(\kappa P-\mathrm{Ph}_{2} \mathrm{PPy}\right)_{2}\right]^{+}$is given in Figure 4 along with selected bond angles and lengths. A distorted square planar coordination polyhedron is observed for the rhodium center with one $\kappa^{2} N, P-\mathrm{Ph}_{2} \mathrm{PPy}$ ligand spanning two cis coordination sites $[\mathrm{N}(2)-\mathrm{Rh}-\mathrm{P}(1)$ 69.50(11) $)$ ] and two $\kappa P-\mathrm{Ph}_{2} \mathrm{PPy}$ ligands at the remaining cis positions $[\mathrm{P}(2)-\mathrm{Rh}-\mathrm{P}(3)$ 96.51(5)o]. Reasonably as consequence of the higher trans influence of phosphano vs. amino groups, $\mathrm{P}(1)-\mathrm{Rh} \quad[2.2901(13) \quad \AA]$ and $\mathrm{P}(3)-\mathrm{Rh}$ [2.3111(13) $\AA$ ] are longer than $\mathrm{P}(2)-\mathrm{Rh}[2.2215(14) \AA]$. As for the four member ring $\mathrm{Rh}-\mathrm{P}(1)-\mathrm{C}(1)-\mathrm{N}(2)$, the puckering angle $\left(\alpha 11.2^{\circ}\right)$ indicates that the ring slightly deviates from planarity $^{72}$ and the short bite angle $[\mathrm{N}(2)-\mathrm{Rh}-\mathrm{P}(\mathrm{1})$ $69.50(11)$ 의 should be responsible for the significant deviation of the pyridine moiety ( $\square$ 18.2 $2^{\circ}, \square 6.9^{\circ}$ ) from the ideal arrangement with respect to the $\mathrm{Rh}-\mathrm{N}(2)$ bond. 


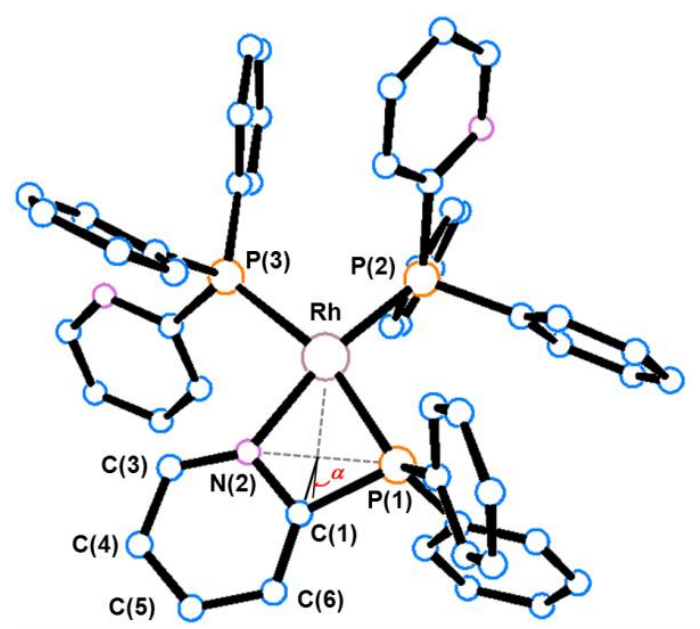

Figure 4. View of the crystal structure of $\left[\mathrm{Rh}\left(\kappa^{2} N, P\right.\right.$ $\left.\left.\mathrm{Ph}_{2} \mathrm{PPy}\right)\left(\kappa P-\mathrm{Ph}_{2} \mathrm{PPy}\right)_{2}\right]^{+}$in $\mathbf{1 4}$. Hydrogen atoms are omitted for clarity. Selected bond lengths $(\AA)$ and angles (o) are: N(2)-Rh 2.130(4), N(2)-Rh-P(1) 69.5o(11), P(2)-Rh-P(3) 96.51(5). Pitch $(\square)$ and yaw $(\square)$ angles of the $N(2)-C(3)-C(4)-C(5)-C(6)-C(1)$ moiety are $\square 18.2^{\circ}, \square 6.9^{\circ}$. Puckering angle $(\alpha)$ between plane $\mathrm{C}(1)-\mathrm{P}(1)-\mathrm{N}(2)$ and plane $\mathrm{Rh}-\mathrm{P}(1)-\mathrm{N}(2)$ is $11.2^{\circ}$.

The formation of two very different compounds in the reaction of 3 with $\mathrm{PA}, 10$ and 13, can be rationalized on the basis of the chemical behavior of the cationic alkynyl species $\left[\mathrm{Rh}(\mathrm{C} \equiv \mathrm{CPh})(\mathrm{cod})\left(\mathrm{Ph}_{2} \mathrm{PPyH}\right)\right]^{+}(\mathbf{C})$ formed by proton transfer of an alkyne ligand to the pyridine fragment of the $\kappa^{1} P$ coordinated $\mathrm{Ph}_{2} \mathrm{PPy}$ ligand (Scheme 5 ).

As we have shown before, this species is involved in the formation of the rhodaheterocyclic species $\mathbf{1 3}$ (pathway i). However, proton transfer to the reaction medium might result in the formation of the neutral alkynyl compound $\left[\mathrm{Rh}(\mathrm{C} \equiv \mathrm{C}-\mathrm{Ph})(\mathrm{cod})\left\{\mathrm{Ph}_{2} \mathrm{PPy}\right\}\right]$ (15) that would further react with 3 to give the alkynyl dinuclear species 10 with release of $\mathrm{Ph}_{2} \mathrm{PPy}$ (pathway ii). The lability of the cod ligand in 3 allows it to act as a scavenger of the released $\mathrm{Ph}_{2} \mathrm{PPy}$ through the formation of $\mathbf{1 4}$. It is worth to mention that the hydrogen bond or proton acceptor power of THF is considered to be similar to or possibly a little less than that of methanol or monomeric water. ${ }^{73}$

This mechanistic proposal requires that $\mathbf{3}$ and $\mathbf{C}$ to be in equilibrium, which is supported by DFT calculations (Figure 3), and fast formation of the final products 10 and 14. Proton transfer to the reaction medium should be facilitated by the low basicity of the pyridine fragment of the coordinated $\mathrm{Ph}_{2} \mathrm{PPy}$ ligand. In fact, protonation of the related compound $\left[\mathrm{RhCl}(\mathrm{cod})\left(i \mathrm{Pr}_{2} \mathrm{PPy}\right)\right]$ result in the formation of the unstable cationic species $\left[\mathrm{RhCl}(\mathrm{cod})\left(\mathrm{Pr}_{2} \mathrm{PPyH}\right)\right]^{+}$that in the decomposition pathway spontaneously release $\mathrm{HCl}$ to give the $[\mathrm{Rh}(\operatorname{cod})(\kappa P, N-$ $\left.\left.i \mathrm{Pr}_{2} \mathrm{PPy}\right)\right]^{+}$species. ${ }^{39}$ As far of the fate of the $\mathrm{H}^{+}$is concerned, the ${ }^{1} \mathrm{H}$ NMR spectrum of the reaction mixture in THF- $d_{8}$ shows a broad signal at $11.15 \mathrm{ppm}$ which could be attributable to a $\mathrm{NH}$ resonance likely of
$\left[\mathrm{Rh}\left(\mathrm{Ph}_{2} \mathrm{PPy}\right)_{2}\left(\mathrm{Ph}_{2} \mathrm{PPyH}\right)\right]^{2+}$, although we have not be able to detect this cation by HRMS of this solution.

As a consequence of the fast proton transfer to the reaction medium, reaction of 3 with $\mathrm{PA}$ in THF selectively gives 10 and the byproduct $\mathbf{1 4}$. However, when the reaction is carried out in $\mathrm{CD}_{2} \mathrm{Cl}_{2}$ proton transfer is not so efficient and the in the increase of $\mathbf{C}$ results in the extensive formation of the rhodaheterocyclic species 13 although the formation of 10 cannot be suppressed.

Scheme 5. Proposed mechanisms for the formation of $\left[\mathrm{Rh}_{2}(\operatorname{cod})_{2}\left(\mu-\mathrm{Ph}_{2} \mathrm{PPy}\right)(\mu-\mathrm{C} \equiv \mathrm{CPh})\right]\left[\mathrm{BF}_{4}\right](10)$.

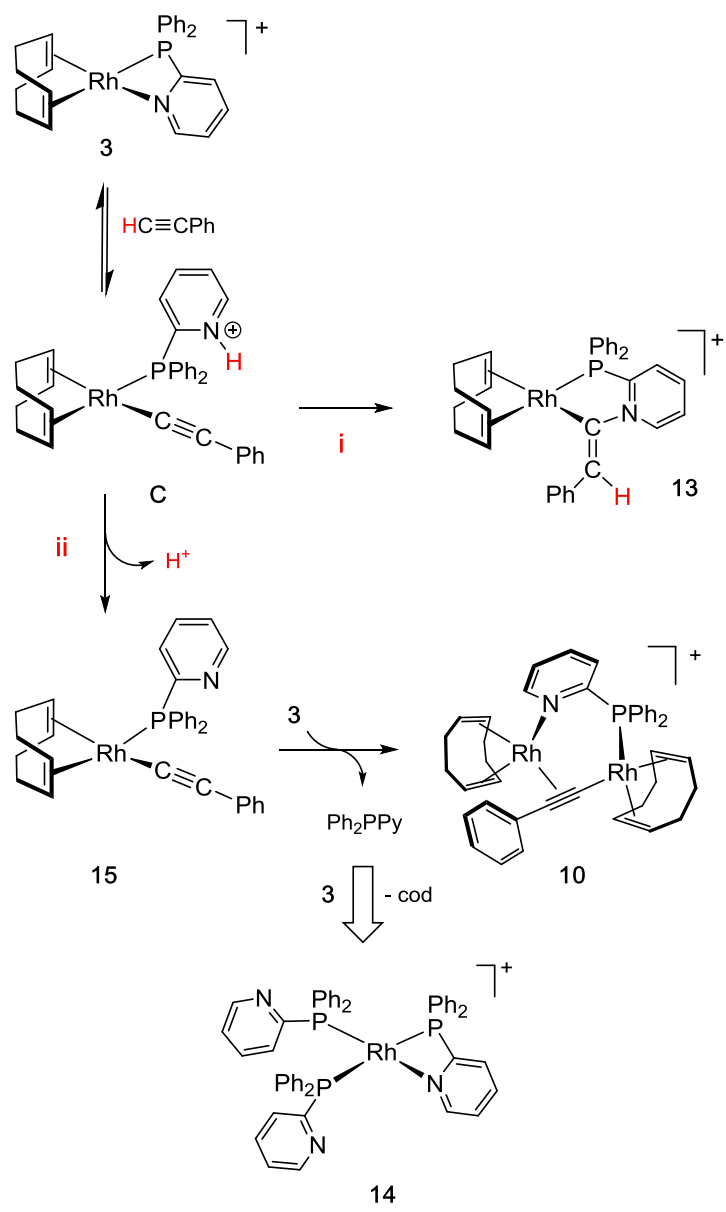

Monitoring of the $\mathrm{PA}$ polymerization initiated by $\left[\mathbf{R h}(\mathbf{c o d})\left(\mathbf{i P r N H}_{2}\right)\left(\mathbf{P h}_{2} \mathbf{P P y}\right)\right]\left[\mathbf{B F}_{4}\right]$. The role of isopropylamine in the initiation process of the polymerization of PA catalyzed by $\left[\mathrm{Rh}(\mathrm{cod})\left(i \mathrm{PrNH}_{2}\right)\left(\mathrm{Ph}_{2} \mathrm{PPy}\right)\right]\left[\mathrm{BF}_{4}\right](\mathbf{8})$ has been investigated by NMR. The polymerization reaction was carried out in an NMR tube and monitored by ${ }^{31} \mathrm{P}\left\{{ }^{1} \mathrm{H}\right\}$ NMR (Figure 5). The addition of 5 molar equiv of PA to an orange solution of $8(0.018 \mathrm{mmol})$ in $\mathrm{CD}_{2} \mathrm{Cl}_{2}(0.5 \mathrm{~mL})$ at $195 \mathrm{~K}$ does not produce an apparent reaction. However, when the temperature was increased the progressive darkening of the solution was observed. Thus, the reaction was monitored by ${ }^{31} \mathrm{P}\left\{{ }^{1} \mathrm{H}\right\} \mathrm{NMR}$ at $220 \mathrm{~K}$ after stirring the solution at room temperature between the measurement in order to slow down the reaction. As can be observed in Figure 5, compound 8 ( $\delta 21.90$ ppm, $J_{\mathrm{P}-\mathrm{Rh}}=155.4$ 
$\mathrm{Hz})$ is almost completely transformed into $\left[\mathrm{Rh}_{2}(\operatorname{cod})_{2}(\mu-\right.$ $\left.\left.\mathrm{Ph}_{2} \mathrm{PPy}\right)(\mu-\mathrm{C} \equiv \mathrm{C}-\mathrm{Ph})\right]^{+}(10)\left(\delta 19.26 \mathrm{ppm}, J_{\mathrm{P}-\mathrm{Rh}}=148.8 \mathrm{~Hz}\right)$, the pentacoordinated species $\left[\mathrm{Rh}(\operatorname{cod})\left(i \mathrm{PrNH}_{2}\right)_{2}\left(\mathrm{Ph}_{2} \mathrm{PPy}\right)\right]^{+}(\mathbf{9})(\delta 22.48 \mathrm{ppm}, \mathrm{br})$ and a new minor species at $\delta 32.00 \mathrm{ppm}\left(J_{\mathrm{P}-\mathrm{Rh}}=161.1 \mathrm{~Hz}\right)$ after 1 min at RT. The concentration of $\mathbf{8}$ steadily decreases over time and completely disappears after $15 \mathrm{~min}$ at RT and only 9 and 10 are observed. Interestingly, the ${ }^{1} \mathrm{H}$ NMR spectrum showed the formation of PPA.
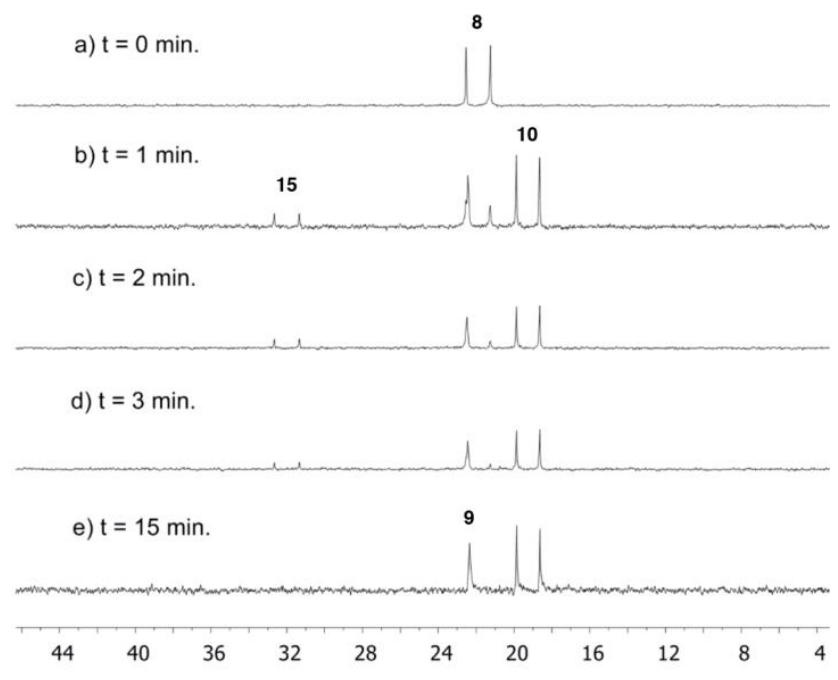

Figure 5. Monitoring of the reaction of 8 (o.018 $\mathrm{mmol}$, 0.036 M) with PA (o.o9 mmol, o.18 M) by ${ }^{31} \mathrm{P}\left\{{ }^{1} \mathrm{H}\right\} \mathrm{NMR}\left(\mathrm{CD}_{2} \mathrm{Cl}_{2}, 220\right.$ $\mathrm{K})$ ( $\mathrm{t}$ is the time at room temperature between spectra).

The minor product has been identified as the alkynyl species $\left[\mathrm{Rh}(\mathrm{C} \equiv \mathrm{CPh})(\mathrm{cod})\left(\mathrm{Ph}_{2} \mathrm{PPy}\right)\right](\mathbf{1 5})$ by comparison of its spectroscopic properties with those of a sample independently prepared. The one-pot reaction of $[\mathrm{Rh}(\mu-$ $\mathrm{OMe})(\mathrm{cod})]_{2}, \mathrm{Ph}_{2} \mathrm{PPy}$ and $\mathrm{PhC} \equiv \mathrm{CH}$ (1:2:2.5) in diethyl ether at $253 \mathrm{~K}$ gave a dark brown solution from which 15 was isolated as an air-sensitive brown solid in $56 \%$ yield (Scheme 6). This compound was not obtained pure $\left({ }^{1} \mathrm{H}\right.$ NMR evidence) and consequently no satisfactory elemental analysis could be obtained. However, the formation of $\mathbf{1 5}$ was substantiated by NMR spectroscopy. In particular, the ${ }^{31} \mathrm{P}\left\{{ }^{1} \mathrm{H}\right\}$ NMR spectrum in $\mathrm{CD}_{2} \mathrm{Cl}_{2}$ showed a doublet at $\delta 32.09\left(J_{\mathrm{P}-\mathrm{Rh}}=161.3 \mathrm{~Hz}\right)$ and the ${ }^{13} \mathrm{C}\left\{{ }^{1} \mathrm{H}\right\}$ NMR spectrum two doublets of doublets at $\delta 121.83\left(\mathrm{dd}, J_{\mathrm{C}-\mathrm{Rh}}=\right.$ 49.3, $\left.J_{\mathrm{C}-\mathrm{P}}=22.1 \mathrm{~Hz}\right)$ and $118.31 \mathrm{ppm}\left(\mathrm{dd}, J_{\mathrm{C}-\mathrm{Rh}}=12.6, J_{\mathrm{C}-\mathrm{P}}<2\right.$ $\mathrm{Hz}$ ) corresponding to the $\mathrm{C}_{\alpha}$ and $\mathrm{C}_{\beta}$ carbon atoms, respectively. On the other hand, the ${ }^{1} \mathrm{H}$ and ${ }^{13} \mathrm{C}\left\{{ }^{1} \mathrm{H}\right\}$ NMR spectra showed two resonances for the $=\mathrm{CH}$ of the cod ligand at $\delta$ 5.66 and $3.90 \mathrm{ppm}$, and $\delta 98.15\left(\mathrm{t}, J_{\mathrm{C}-\mathrm{Rh}}=16.50\right.$ and $J_{\mathrm{C}-\mathrm{P}}=$ $8.60 \mathrm{~Hz})$ and $85.61\left(\mathrm{~d}, J_{\mathrm{C}-\mathrm{Rh}}=8.1 \mathrm{~Hz}\right)$, which is in agreement with a square-planar structure of symmetry $C_{\mathrm{s}}$.

Scheme 6. Synthesis of compound $[\mathrm{Rh}(\mathrm{C} \equiv \mathrm{C}$ $\left.\mathrm{Ph})(\operatorname{cod})\left\{\mathrm{Ph}_{2} \mathrm{PPy}\right\}\right]($ 15).

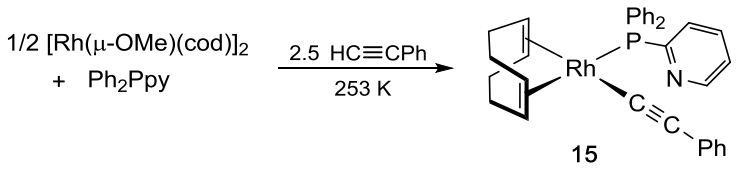

The formation of 10 and 15, both lacking $i \mathrm{PrNH}_{2}$ ligands, in the reaction of $\mathbf{8}$ with PA also explains the formation of $\left[\mathrm{Rh}(\mathrm{cod})\left(i \mathrm{PrNH}_{2}\right)_{2}\left(\mathrm{Ph}_{2} \mathrm{PPy}\right)\right]\left[\mathrm{BF}_{4}\right](9)$. Thus, the pentacoordinated species 9 results from the reaction of $\mathbf{8}$ with the $i \mathrm{PrNH}_{2}$ released in the formation of $\mathbf{1 0}$ and $\mathbf{1 5}$.

Even though compound $\left[\mathrm{Rh}(\mathrm{C} \equiv \mathrm{CPh})(\operatorname{cod})\left(\mathrm{Ph}_{2} \mathrm{PPy}\right)\right]$ (15) was not obtained analytically pure its performance on PA polymerization has been investigated. Interestingly, compound 15 catalyzes the polymerization of PA in tetrahydrofuran under our standard reaction conditions (293 $\left.\mathrm{K},[\mathrm{PA}]_{\mathrm{o}}=0.25 \mathrm{M},[\mathrm{PA}]_{\mathrm{o}} /[\mathrm{Rh}]=100\right)$ attaining a $65 \%$ conversion in $2 \mathrm{~h}$. The isolated PPA showed a bimodal molar mass distribution with a main fraction of $M_{\mathrm{w}} 2.22 \mathrm{E}+05$ and polydispersity of 1.65. Interestingly, the molar mass of this polymer is of the same order of magnitude than that of the polymer obtained with the catalytic system $3 / \mathrm{PrNH}_{2}\left(M_{\mathrm{w}}\right.$ of $3.42 \mathrm{E}+05$; entry 5 , Table 1$)$ although the latter showed a slightly lower polydispersity likely due to the effect of the excess of $i \mathrm{PrNH}_{2}$ in the reaction medium.

The polymerization of $\mathrm{PA}$ by the initiator $\left[\mathrm{Rh}(\mathrm{nbd})\left(i \mathrm{PrNH}_{2}\right)\left(\mathrm{Ph}_{2} \mathrm{PPy}\right)\right]\left[\mathrm{BF}_{4}\right](7)$ has been also monitored by ${ }^{31} \mathrm{P}\left\{{ }^{1} \mathrm{H}\right\}$ NMR following the same experimental procedure described above. The reaction was carried in $\mathrm{CD}_{2} \mathrm{Cl}_{2}(0.5 \mathrm{~mL})$ using a $[\mathrm{PA}] /[7]$ ratio of $5 / 1$ at $195 \mathrm{~K}$ (0.018 $\mathrm{mmol}$ of 7 ). The behavior of this system is similar to that found for the related cod compound $\mathbf{8}$ described before. Thus, together with the characteristic doublet of complex 7 , the dinuclear compound $\left[\mathrm{Rh}_{2}(\mathrm{nbd})_{2}\left(\mu-\mathrm{Ph}_{2} \mathrm{PPy}\right)(\mu-\right.$ $\mathrm{C} \equiv \mathrm{CPh})]\left[\mathrm{BF}_{4}\right](\mathbf{1 2})$, showing a doublet at $\delta 24.34 \mathrm{ppm}(\mathrm{d}$, $J_{\mathrm{P}-\mathrm{Rh}}=154.2 \mathrm{~Hz}$ ), was immediately formed. The concentration of this species increases with time while that of the catalyst precursor decreases. In this case it has not been possible to detect the species $\left[\mathrm{Rh}(\mathrm{C} \equiv \mathrm{C}-\mathrm{Ph})(\mathrm{nbd})\left(\mathrm{Ph}_{2} \mathrm{PPy}\right)\right]$ likely responsible for the initiation process. However, the broad resonance observed at $\delta \approx 23.8 \mathrm{ppm}$ possibly corresponds to the pentacoordinated species $\left[\mathrm{Rh}(\mathrm{nbd})\left(i \mathrm{PrNH}_{2}\right)_{2}\left(\mathrm{Ph}_{2} \mathrm{PPy}\right)\right]\left[\mathrm{BF}_{4}\right]$ (see Supporting Information).

The role played by the cocatalyst $i \mathrm{PrNH}_{2}$ in the polymerization of PA by 3 is shown in Scheme 7. As it has been shown before, coordination of $i \mathrm{PrNH}_{2}$ results in the formation of $\mathbf{8}$. Then, coordination of PA is followed by its deprotonation by $i \mathrm{PrNH}_{2}$ to afford the neutral alkynyl intermediate $\left[\mathrm{Rh}(\mathrm{C} \equiv \mathrm{CPh})(\operatorname{cod})\left(\mathrm{Ph}_{2} \mathrm{PPy}\right)\right]$ (15). The efficient proton transfer from the coordinated PA to $i \mathrm{PrNH}_{2}$, likely through the intermediation of the pyridyl fragment, is driven by its stronger basicity $\left(\mathrm{p} K_{\mathrm{a}}=10.63\right)^{74}$ compared with that of the pyridyl fragment taken pyridine as a reference $\left(\mathrm{p} K_{\mathrm{a}}=5.23\right) .{ }^{75}$ As a consequence, the formation of the rhodaheterocyclic compound 13 is suppressed but not that of 10 that is likely formed by reaction of $\mathbf{1 5}$ with $\mathbf{8}$. It is worth of mention that the presence of only one molar 
equiv of $i \mathrm{PrNH}_{2}$ in the catalytic system allows for a significant concentration of the key alkynyl intermediate $\mathbf{1 5}$ that is likely the initiating species involved in the generation of the rhodium-vinyl species responsible for the propagation step. This proposal is based on the catalytic performance exhibited by $\mathbf{1 5}$ and in our previous mechanistic studies on PA polymerization by rhodium(I) catalysts featuring functionalized phosphine ligands of hemilabile character. ${ }^{32,33}$ In addition, recent theoretical studies by Morokuma et al. on the rhodium-catalyzed polymerization of PA have shown that PA insertion into the Rh-alkynyl bond is possible as initiation step. ${ }^{76}$ Interestingly, the energy barrier for the PA insertion into the Rh-alkynyl bond (initiation step) is almost $4 \mathrm{Kcal} \mathrm{mol}^{-1}$ higher than the barrier for the insertion into the Rh-vinyl bond (propagation step) which is in agreement with the low initiation efficiencies (0.5-7\%) of the 2(diphenylphosphino)pyride based rhodium(I) catalysts (Table 1).

Polymerization of PA initiated by $\left[R_{2}(\operatorname{cod})_{2}(\mu-\right.$ $\left.\left.\mathbf{P h}_{2} \mathbf{P P y}\right)(\boldsymbol{\mu}-\mathbf{C} \equiv \mathbf{C P h})\right]\left[\mathbf{B F}_{4}\right](\mathbf{1 0})$. Once the species involved in the PA polymerization by the catalytic system $3 / \mathrm{PrNH}_{2}$ have been identified, the reactivity of the dinuclear complex $\left[\mathrm{Rh}_{2}(\operatorname{cod})_{2}\left(\mu-\mathrm{Ph}_{2} \mathrm{PPy}\right)(\mu-\mathrm{C} \equiv \mathrm{CPh})\right]\left[\mathrm{BF}_{4}\right](\mathbf{1 0})$ has been investigated by NMR. The ${ }^{1} \mathrm{H}$ NMR spectrum corresponding to the addition of PA to a solution of complex 10 in $\mathrm{CD}_{2} \mathrm{Cl}_{2}$ at $298 \mathrm{~K}$ showed no polymerization of PA (Figure 6). However, after the addition of $1 \mathrm{mmol}$ of $i \mathrm{PrNH}_{2}$ formation of PPA was observed. Interestingly, the addition of further PA ( $5 \mathrm{mmol}$ ) resulted in an increased of the intensity of the PPA resonances. The ${ }^{31} \mathrm{P}\left\{{ }^{1} \mathrm{H}\right\}$ NMR spectra associated to the ${ }^{1} \mathrm{H}$ NMR spectra revealed that the pentacoordinated species $\left[\mathrm{Rh}(\mathrm{cod})\left(i \mathrm{PrNH}_{2}\right)_{2}\left(\mathrm{Ph}_{2} \mathrm{PPy}\right)\right]^{+}(\mathbf{9})$ is formed in parallel to the polymerization reaction. In fact, the amount of this species increases with the successive PA loads while decreasing that one of 10 which suggests that 9 might be considered as the resting state of the catalytic system 1o/i $\mathrm{PrNH}_{2}$.

Scheme 8. Proposed mechanism for the formation of the catalytic active species 15 in the catalytic system 10/iPrNH . $_{2}$
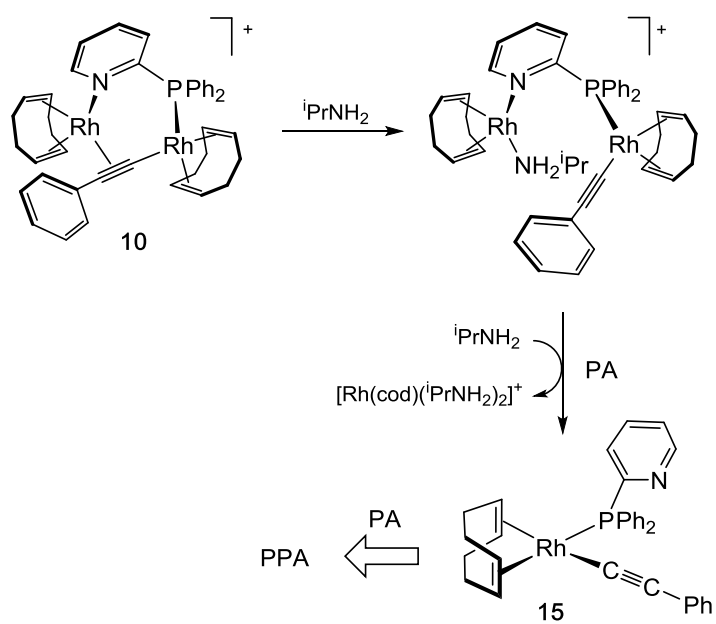

a)

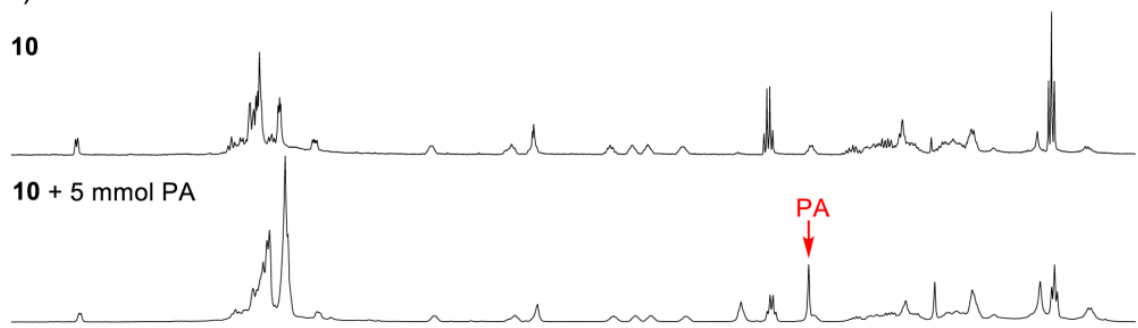

$10+5 \mathrm{mmol} \mathrm{PA}+1 \mathrm{mmol} i \mathrm{PrNH}_{2}$

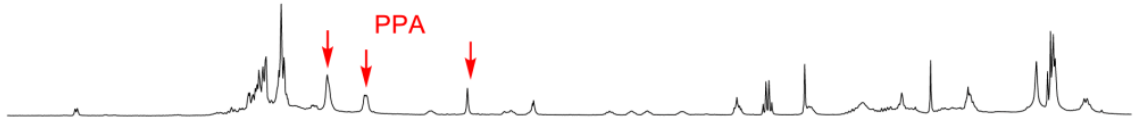

$10+5 \mathrm{mmol} \mathrm{PA}+1 \mathrm{mmol} \mathrm{PrNH}_{2}+5 \mathrm{mmol} \mathrm{PA}$

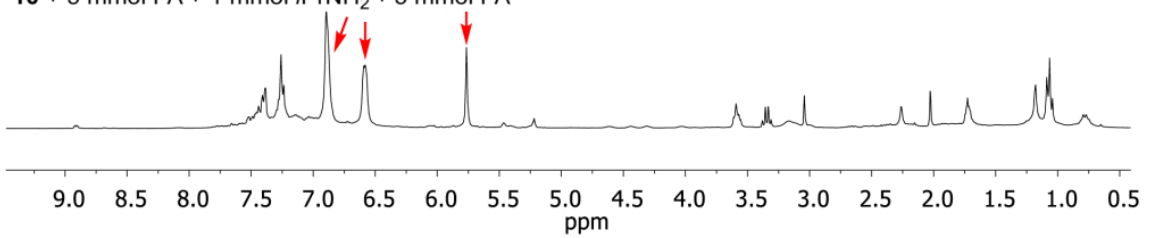

b)

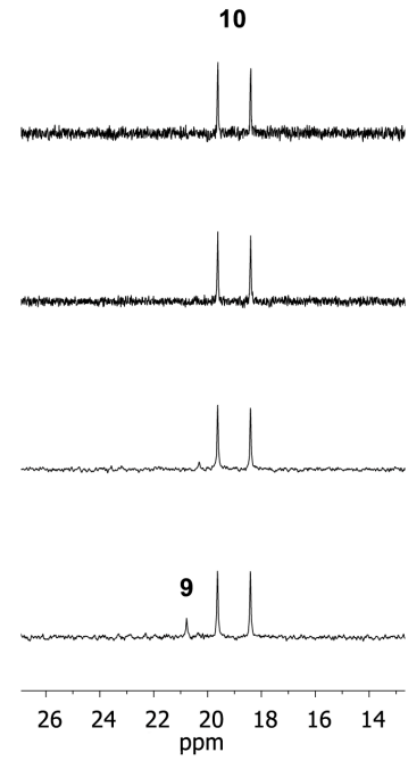

Figure 6. Monitoring of the polymerization of PA by the catalytic system 1o/iPrNH ${ }_{2},[\mathrm{Rh}]:[\mathrm{PA}]:\left[\mathrm{PrNH}_{2}\right]$ 1:5:1. $[\mathrm{Rh}]=0.012 \mathrm{M}$ in $\mathrm{CD}_{2} \mathrm{Cl}_{2}(0.5 \mathrm{~mL})$ at $\left.\left.298 \mathrm{~K}: \mathrm{a}\right){ }^{1} \mathrm{H} \mathrm{NMR}, \mathrm{b}\right){ }^{31} \mathrm{P}\left\{{ }^{1} \mathrm{H}\right\}$ NMR. 
Scheme 7. Involved species in the polymerization of PA by the catalytic system $3 / \mathrm{iPrNH}_{2}$.

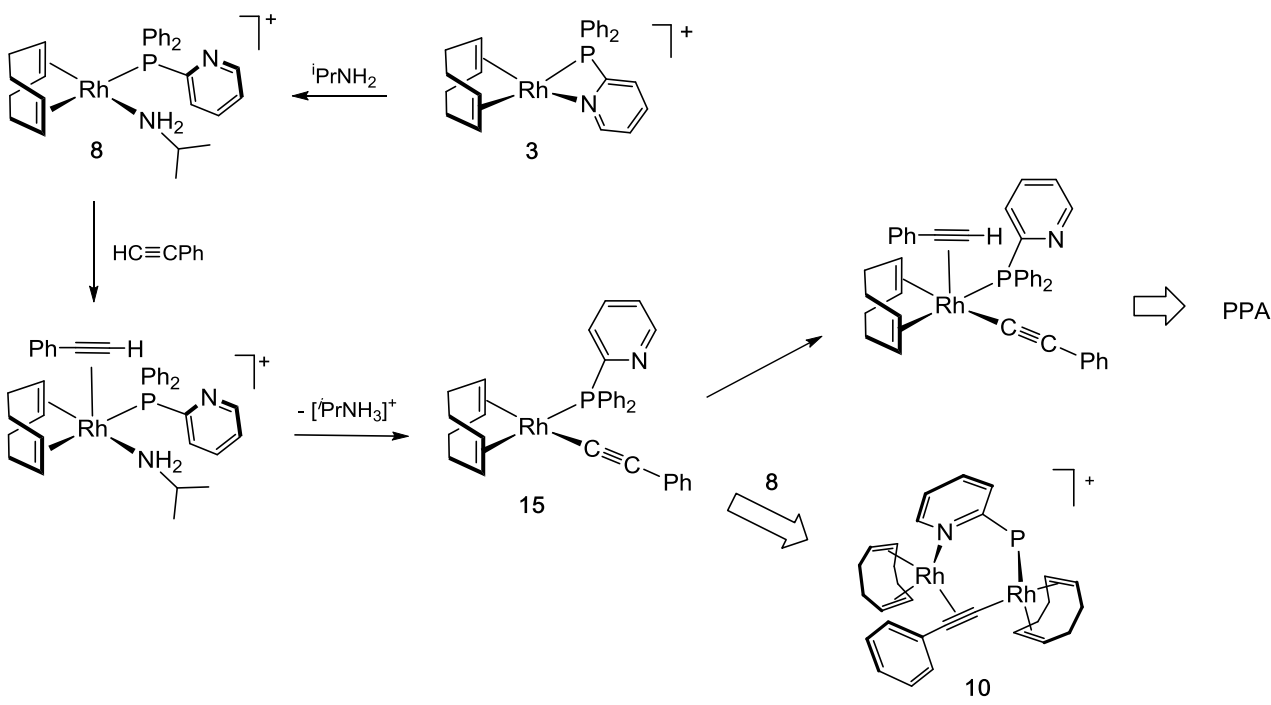

Interestingly, compound 10 reacts with $i \mathrm{PrNH}_{2}$ which is in agreement with catalytic activity of the system 10/i $\mathrm{PrNH}_{2}$. The ${ }^{31} \mathrm{P}\left\{{ }^{1} \mathrm{H}\right\}$ NMR spectrum of a solution of 10 in $\mathrm{CD}_{2} \mathrm{Cl}_{2}$ after the addition of 1 molar equiv of $i \mathrm{PrNH}_{2}$ showed a broad signal at $\delta \approx 19.66 \mathrm{ppm}$ that does not resolve at low temperature. Initially, the addition of $i \mathrm{PrNH}_{2}$ might induce the decoordination of the $\pi$-alkynyl ligand affording a dinuclear species supported exclusively by a 2-(diphenylphosphino)pyridine ligand which should be fluxional. The subsequent addition of PA might result in the fragmentation of the dinuclear species and the generation of the initiating species 15 (Scheme 8). Therefore, compound 10 acts as a reservoir of initiating species which explains its consumption in the addition of successive PA loads. This result also explains the higher catalytic activity of the systems $3 / \mathrm{PrNH}_{2}$ and $4 / i \mathrm{PrNH}_{2}$ compared to $\left[\mathrm{Rh}(\mathrm{nbd})\left\{\mathrm{Ph}_{2} \mathrm{P}\left(\mathrm{CH}_{2}\right)_{2} \mathrm{Py}\right\}\right]^{+}(6)$ as consequence of the higher concentration of $\mathbf{1 5}$ under this conditions, $\left[i \mathrm{PrNH}_{2}\right] /[\mathrm{Rh}]=10$, that is also reflected in the higher initiation efficiencies (4-7\%).

\section{CONCLUSIONS}

The catalytic activity in the polymerization of phenylacetylene (PA) of several rhodium(I) catalysts containing pyridine functionalized phosphine ligands, 2(diphenylphosphino)pyridine and 2-(2(diphenylphosphino)ethyl)pyridine, has been investigated. In contrast with $\left[\mathrm{Rh}(\mathrm{nbd})\left\{\mathrm{Ph}_{2} \mathrm{P}\left(\mathrm{CH}_{2}\right)_{2} \mathrm{Py}\right\}\right]^{+}$that showed a moderate catalytic activity, the mono- and dinuclear complexes featuring a 2(diphenylphosphino)pyridine ligand, $\left[\mathrm{Rh}(\operatorname{cod})\left(\mathrm{Ph}_{2} \mathrm{PPy}\right)\right]^{+}$ and $\left[\mathrm{Rh}(\mathrm{nbd})\left(\mathrm{Ph}_{2} \mathrm{PPy}\right)\right]_{2}{ }^{2+}$, were completely inactive. However, in the presence of a cocatalyst as $i \mathrm{PrNH}_{2}$ both catalytic systems efficiently polymerize PA affording highly stereoregular PPA polymers of $M_{\mathrm{w}} 3.42 \mathrm{E}+05$ and
2.02E+05, respectively, with polydispersities of 1.39 and initiation efficiencies of 4-7 \%.

Compounds $\left[\mathrm{Rh}(\text { diene })\left(\mathrm{Ph}_{2} \mathrm{PPy}\right)\right]_{\mathrm{n}}{ }^{\mathrm{n}+}$ react with $\mathrm{PA}$ in tetrahydrofuran to give the dinuclear species $\left[\mathrm{Rh}_{2}(\text { diene })_{2}\left(\mu-\mathrm{Ph}_{2} \mathrm{PPy}\right)(\mu-\mathrm{C} \equiv \mathrm{C}-\mathrm{R})\right]^{+}$, featuring a $\mathrm{Ph}_{2} \mathrm{PPy}$ bridging ligand and an alkynyl ligand coordinated in a $\mu-$ $\eta^{1}: \eta^{2}$ fashion, which have shown no activity in PA polymerization. In addition, the reaction of $\left[\mathrm{Rh}(\mathrm{cod})\left(\mathrm{Ph}_{2} \mathrm{PPy}\right)\right]^{+}$with $\mathrm{PA}$ in dichloromethane also gave the mononuclear compound $\left[(\mathrm{cod}) \mathrm{Rh}\left(\mathrm{Ph}_{2} \mathrm{PC}_{5} \mathrm{H}_{4} \mathrm{~N}-\right.\right.$ $\mathrm{C}=\mathrm{CHPh})]^{+}$that features a five-membered rhodaheterocycle resulting from the coupling of an alkyne molecule and the pyridine fragment of the $\mathrm{Ph}_{2} \mathrm{PPy}$ ligand. DFT calculations support an intramolecular alkyne-vinylidene transformation involving the alkynyl species $[\mathrm{Rh}(\mathrm{C} \equiv \mathrm{C}$ $\left.\mathrm{Ph})(\operatorname{cod})\left\{\mathrm{Ph}_{2} \mathrm{PPyH}\right\}\right]^{+}$, which is formed by deprotonation of coordinated phenylacetylene assisted by the pyridine fragment of the $\kappa^{1} P$ coordinated ligand. This species is also key in the formation of the dinuclear $\left[\mathrm{Rh}_{2}(\operatorname{cod})_{2}(\mu-\right.$ $\left.\left.\mathrm{Ph}_{2} \mathrm{PPy}\right)(\mu-\mathrm{C} \equiv \mathrm{C}-\mathrm{R})\right]^{+}$species by proton transfer to the reaction medium and further reaction with $\left[\mathrm{Rh}(\operatorname{cod})\left(\mathrm{Ph}_{2} \mathrm{PPy}\right)\right]^{+}$that as a scavenger of the released $\mathrm{Ph}_{2} \mathrm{PPy}$ through the formation of $\left[\mathrm{Rh}\left(\mathrm{Ph}_{2} \mathrm{PPy}\right)_{3}\right]^{+}$.

Although both compounds $\left[\mathrm{Rh}(\text { diene })\left(\mathrm{Ph}_{2} \mathrm{PPy}\right)\right]_{\mathrm{n}}{ }^{\mathrm{n}+}$ react with $i \mathrm{PrNH}_{2}$ to give the mononuclear $\left[\mathrm{Rh} \text { (diene) }\left(i \mathrm{PrNH}_{2}\right)\left(\mathrm{Ph}_{2} \mathrm{PPy}\right)\right]^{+}$and $\left[\mathrm{Rh} \text { (diene) }\left(i \mathrm{PrNH}_{2}\right)_{2}\left(\mathrm{Ph}_{2} \mathrm{PPy}\right)\right]^{+}$species, the role of the cocatalyst is believed to be involved in the efficient proton transfer from the coordinated PA to $\mathrm{PrNH}_{2}$ that allows for a significant concentration of the key alkynyl species $\left[\mathrm{Rh}(\mathrm{C} \equiv \mathrm{CPh})(\operatorname{cod})\left(\mathrm{Ph}_{2} \mathrm{PPy}\right)\right]$ that is likely the initiating species involved in the generation of the rhodiumvinyl species responsible for the propagation step. In fact, this species has been detected in situ by ${ }^{31} \mathrm{P}\left\{{ }^{1} \mathrm{H}\right\}$ NMR in the PA polymerization initiated by $\left[\mathrm{Rh}(\mathrm{cod})\left(i \mathrm{PrNH}_{2}\right)\left(\mathrm{Ph}_{2} \mathrm{PPy}\right)\right]^{+}$and has been independently 
prepared from $[\mathrm{Rh}(\mu-\mathrm{OMe})(\operatorname{cod})]_{2}, \mathrm{Ph}_{2} \mathrm{PPy}$ and $\mathrm{PhC} \equiv \mathrm{CH}$. $\left[\mathrm{Rh}(\mathrm{C} \equiv \mathrm{CPh})(\operatorname{cod})\left(\mathrm{Ph}_{2} \mathrm{PPy}\right)\right]$ efficiently catalyzed the polymerization of PA affording a PPA of similar molar mass than that obtained with the catalytic system $\left[\mathrm{Rh}(\mathrm{cod})\left(\mathrm{Ph}_{2} \mathrm{PPy}\right)\right]^{+} / i \mathrm{PrNH}_{2}$.

Finally, the distinct behavior of compounds $\left[\mathrm{Rh} \text { (diene) }\left(\mathrm{Ph}_{2} \mathrm{PPy}\right)\right]_{\mathrm{n}}{ }^{\mathrm{n}+}$ and $\left[\mathrm{Rh} \text { (diene) }\left\{\mathrm{Ph}_{2} \mathrm{P}\left(\mathrm{CH}_{2}\right)_{n} \mathrm{NMe}_{2}\right\}\right]^{+}$as $\mathrm{PA}$ polymerization catalysts is a consequence of the binucleating ability of the $\mathrm{Ph}_{2} \mathrm{PPy}$ ligand in combination with the lower basicity of the pyridine fragment compared to that of the dimethylamino fragment which allows for the stabilization of the inactive alkynyl-bridge dinuclear species.

\section{EXPERIMENTAL SECTION}

Synthesis. All experiments were carried out under an atmosphere of argon using Schlenk techniques or glovebox. Solvents were distilled immediately prior to use from the appropriate drying agents or obtained from a Solvent Purification System (Innovative Technologies). $\mathrm{CDCl}_{3}, \mathrm{CD}_{2} \mathrm{Cl}_{2}$ and acetone- $d_{6}$ (Euriso-top) were dried using activated molecular sieves. Phenylacetylene $\left(\right.$ Aldrich $^{\odot}$ ) was purified by vacuum distillation from $\mathrm{CaH}_{2}$ and stored over molecular sieves. 1-ter-butil-4ethynylbenzene was purchased from Acros Organics and used as received. 2-(Diphenylphosphino)pyridine, $\mathrm{Ph}_{2} \mathrm{PPy}$, and 2-(2(diphenylphosphino)ethyl)pyridine, $\mathrm{Ph}_{2} \mathrm{P}\left(\mathrm{CH}_{2}\right)_{2} \mathrm{Py}$, were purchased from Aldrich ${ }^{\odot}$ and used as received. The compounds $\left[\mathrm{RhCl}(\mathrm{cod})\left(\mathrm{Ph}_{2} \mathrm{PPy}\right)\right](\mathbf{1})^{38,39}$ and $\left[\mathrm{RhCl}(\mathrm{nbd})\left(\mathrm{Ph}_{2} \mathrm{PPy}\right)\right](\mathbf{2}),{ }^{39}$ and the starting materials $[\mathrm{Rh}(\mu-\mathrm{Cl})(\text { diene })]_{2}\left(\right.$ diene $\left.=\operatorname{cod},{ }^{77} \mathrm{nbd}^{78}\right)$ and $[\mathrm{Rh}(\mu-\mathrm{OMe})(\mathrm{cod})]_{2}^{79}$ were prepared as described in the literature.

Scientific Equipment. C, $\mathrm{H}$ and $\mathrm{N}$ analyses were carried out in a Perkin-Elmer 2400 Series II CHNS/O analyzer. ${ }^{1} \mathrm{H}$ and ${ }^{13} \mathrm{C}\left\{{ }^{1} \mathrm{H}\right\}$ NMR spectra were recorded on a Bruker Avance 300 (300.1276 $\mathrm{MHz}$ and $75.4792 \mathrm{MHz}$ ) or Bruker Avance $400(400.1625 \mathrm{MHz}$ and $100.6127 \mathrm{MHz}$ ) spectrometers. NMR chemical shifts are reported in ppm relative to tetramethylsilane and referenced to partially deuterated solvent resonances. Coupling constants $(J)$ are given in Hertz. Spectral assignments were achieved by combination of ${ }^{1} \mathrm{H}-{ }^{1} \mathrm{H}$ COSY, ${ }^{13} \mathrm{C}\left\{{ }^{1} \mathrm{H}\right\}$-APT and ${ }^{1} \mathrm{H}^{-13} \mathrm{C}$ HSQC experiments. MALDI-TOF mass spectra were obtained on a Bruker MICROFLEX spectrometer using DCTB, trans-2-[3-(4-tertbutylphenyl)-2-methyl-2-propenylidene]malononitrile, as matrix. ${ }^{80}$ Conductivities were measured in ca. 5 10-4 M acetone solutions of the complexes using a Philips PW 9501/o1 conductimeter.The absolute molecular weight averages $\left(M_{\mathrm{n}}\right.$ and $\left.M_{\mathrm{w}}\right)$, polydispersity (PDI, $M_{\mathrm{w}} / M_{\mathrm{n}}$ ) and molecular weight distribution were determined by SEC-MALS at the Chromatography and Spectroscopy Service of the ISQCH. SEC-MALS analyses were carried out using a Waters 2695 instrument, equipped with three PL-Gel Mixed B LS columns fitted to a MALS detector (MiniDawn Treos, Wyatt) and a differential refractive index detector (Optilab Rex, Wyatt). The polymer solutions in THF $(\approx 2.0$ $\mathrm{mg} / \mathrm{mL}$ ) were filtered through a $0.45 \mu \mathrm{m}$ PTFE membrane filter before being injected in the GPC systems. To minimize sample degradation the analyses were carried out immediately after the dissolution of the polymer sample in THF. ${ }^{81,82}$ Data analysis was performed with ASTRA Software from Wyatt. The samples were eluted at $25^{\circ} \mathrm{C}$ with $\mathrm{THF}$ at a flow rate of $1.0 \mathrm{~mL} / \mathrm{min}$. The reported $\mathrm{dn} / \mathrm{dc}$ value of $0.286_{4} \mathrm{~mL} \mathrm{~g}^{-1}$ determined at $633 \mathrm{~nm}$ for atactic $\mathrm{PPA}^{83}$ was used which resulted in calculated mass recov- eries that were in reasonable agreement with the theoretical values. $^{84}$

Synthesis of the complexes. $\left[\mathrm{Rh}(\operatorname{cod})\left(\mathrm{Ph}_{2} \mathrm{PPy}\right)\right]\left[\mathrm{BF}_{4}\right]$ (3). $\mathrm{AgBF}_{4}$ (79 $\left.\mathrm{mg}, 0.41 \mathrm{mmol}\right)$ was added to a suspension of $[\mathrm{Rh}(\mu-$ $\mathrm{Cl})(\mathrm{cod})]_{2}$ (100 $\left.\mathrm{mg}, 0.203 \mathrm{mmol}\right)$ in THF (10 $\mathrm{mL}$ ). The resulting suspension was stirred for $30 \mathrm{~min}$ and the formed $\mathrm{AgCl}$ removed by filtration to give a pale yellow solution. The solution was concentrated under vacuum to ca. $5 \mathrm{~mL}$ and then cooled to 273 $\mathrm{K}$. The slow addition of a solution of $\mathrm{Ph}_{2} \mathrm{PPy}(107 \mathrm{mg}, 0.406$ $\mathrm{mmol})$ in THF $(4 \mathrm{~mL})$ gave immediately a yellow suspension. The suspension was concentrated to half of the volume and then diethyl ether $(4 \mathrm{~mL})$ was added. The yellow solid was filtered, washed with a 1:1 THF/diethyl ether mixture $(3 \times 3 \mathrm{~mL})$ and dried in vacuo. Yield: $68 \%$. Anal. Calcd. for $\mathrm{C}_{25} \mathrm{H}_{26} \mathrm{BF}_{4} \mathrm{NPRh}$ : $\mathrm{C}$, 53.08; $\mathrm{H}, 4.67$; N, 2.50. Found: C, 52.95; H, 4.65; N, 2.52. ${ }^{1} \mathrm{H}$ NMR (193 K, $\left.\mathrm{CD}_{2} \mathrm{Cl}_{2}\right): \delta 8.10(\mathrm{~s}, 1 \mathrm{H}, \mathrm{H}-6$ Py), $7.80(\mathrm{~m}, 1 \mathrm{H}, \mathrm{H}-4$ Py), 7.72-7.42 (m, $12 \mathrm{H}, 10 \mathrm{H} \mathrm{Ph}, \mathrm{H}-3$ and $\left.\mathrm{H}_{-5} \mathrm{Py}\right), 5.44$ (br, $2 \mathrm{H},=\mathrm{CH}$ cod), $4.62(\mathrm{br}$, $2 \mathrm{H},=\mathrm{CH} \operatorname{cod}), 2.48$ (br, $\left.4 \mathrm{H}, \mathrm{CH}_{2} \operatorname{cod}\right), 2.17\left(\mathrm{br}, 4 \mathrm{H}, \mathrm{CH}_{2} \operatorname{cod}\right)$. ${ }^{31} \mathrm{P}\left\{{ }^{1} \mathrm{H}\right\}$ RMN (193 K, CD $\left.\mathrm{Cl}_{2}\right): \delta-40.03\left(\mathrm{~d}, J_{\mathrm{P}-\mathrm{Rh}}=126.0\right) .{ }^{13} \mathrm{C}\left\{{ }^{1} \mathrm{H}\right\}$ NMR $\left(193 \mathrm{~K}, \mathrm{CD}_{2} \mathrm{Cl}_{2}\right): \delta 169.7\left(\mathrm{~d}, J_{\mathrm{C}-\mathrm{P}}=54.2, \mathrm{C}-\mathrm{P}\right.$ Py), $150.8\left(\mathrm{~d}, J_{\mathrm{C}-\mathrm{P}}\right.$ = 11.1, NCH Py), 149.0 (d, JC-P = 13.2, CH Py), 141.3 (CH Py), 133.7 $\left(\mathrm{d}, J_{\mathrm{C}-\mathrm{P}}=13.5, \mathrm{C}_{\mathrm{o}}, \mathrm{Ph}\right), 132.7\left(\mathrm{~d}, J_{\mathrm{C}-\mathrm{P}}=2.3, \mathrm{C}_{\mathrm{p}}, \mathrm{Ph}\right), 130.2\left(\mathrm{~d}, J_{\mathrm{C}-\mathrm{P}}=\right.$ 11.1, $\left.\mathrm{C}_{\mathrm{m}}, \mathrm{Ph}\right), 128.3$ (CH Py), $125.8\left(\mathrm{~d}, J_{\mathrm{C}-\mathrm{P}}=42.3, \mathrm{C}_{\mathrm{i}}\right), 100.7(\mathrm{br},=\mathrm{CH}$ cod), 8o.o (br, =CH cod), 32.0 ( $\mathrm{CH}_{2}$ cod), $28.5\left(\mathrm{CH}_{2} \operatorname{cod}\right)$. MS (MALDI-Tof, $\left.\mathrm{CH}_{2} \mathrm{Cl}_{2}, \mathrm{~m} / \mathrm{z}\right): 474.4\left(\mathrm{M}^{+}, 100 \%\right)$. $\Lambda_{\mathrm{M}}$ (acetone, $5.0 \mathrm{x}$ $\left.10^{-4} \mathrm{M}\right)=84 \Omega^{-1} \mathrm{~cm}^{2} \mathrm{~mol}^{-1}$.

$\left[\mathbf{R h}(\mathbf{n b d})\left(\boldsymbol{\mu}-\mathbf{P h}_{2} \mathbf{P P y}\right)\right]_{2}\left[\mathbf{B F}_{4}\right]_{2}(\mathbf{4})$. The compound was prepared following the procedure described for 3 starting from $\mathrm{AgBF}_{4}(85$ $\mathrm{mg}, 0.436 \mathrm{mmol}), \mathrm{Rh}(\mu-\mathrm{Cl})(\mathrm{nbd})]_{2}$ (10o $\left.\mathrm{mg}, 0.217 \mathrm{mmol}\right)$ and $\mathrm{Ph}_{2} \mathrm{PPy}(115 \mathrm{mg}, 0.434 \mathrm{mmol}$ ), and obtained as a violet microcrystalline solid in $72 \%$ yield. Anal. Calcd. for $\mathrm{C}_{48} \mathrm{H}_{44} \mathrm{~B}_{2} \mathrm{~F}_{8} \mathrm{~N}_{2} \mathrm{P}_{2} \mathrm{Rh}_{2}: \mathrm{C}$, 52.88; H, 4.07; N, 2.57. Found: C, 52.77; H, 4.05; N, 2.57. ${ }^{1} \mathrm{H}$ NMR $\left(233 \mathrm{~K}, \mathrm{CD}_{2} \mathrm{Cl}_{2}\right): \delta 9.11\left(\mathrm{~d}, J_{\mathrm{H}-\mathrm{H}}=5.1,2 \mathrm{H}, \mathrm{H}-6 \mathrm{Py}\right), 7.64(\mathrm{~m}, 10 \mathrm{H}$, $\mathrm{Ph}$ ), 7.50 (m, 10H, Ph, H-4 Py), 7.28 (m, $2 \mathrm{H}, \mathrm{H}-3$ or $\mathrm{H}-5 \mathrm{Py}), 7.00$ $(\mathrm{m}, 2 \mathrm{H}, \mathrm{Ph}), 6.75(\mathrm{~m}, 2 \mathrm{H}, \mathrm{H}-3$ or $\mathrm{H}-5 \mathrm{Py}), 5.59$ (br, $2 \mathrm{H},=\mathrm{CH}$ nbd), $5.00(\mathrm{br}, 2 \mathrm{H},=\mathrm{CH}$ nbd), $4.62(\mathrm{br}, 2 \mathrm{H},=\mathrm{CH}$ nbd), $4.30(\mathrm{br}, 2 \mathrm{H}, \mathrm{CH}$ nbd), $4.04\left(\mathrm{br}, 2 \mathrm{H}, \mathrm{CH}\right.$ nbd), $3.75\left(\mathrm{~m}, 2 \mathrm{H},=\mathrm{CH}\right.$ nbd), 1.6o $\left(\mathrm{AB}_{\mathrm{q}}\right.$, $\left.J_{\mathrm{H}-\mathrm{H}}=8.9,4 \mathrm{H}, \mathrm{CH}_{2} \mathrm{nbd}\right) .{ }^{31} \mathrm{P}\left\{{ }^{1} \mathrm{H}\right\} \mathrm{NMR}\left(233 \mathrm{~K}, \mathrm{CD}_{2} \mathrm{Cl}_{2}\right)$ : $\delta 20.62(\mathrm{~d}$, $\left.J_{\mathrm{P}-\mathrm{Rh}}=158.8\right) .{ }^{13} \mathrm{C}\left\{{ }^{1} \mathrm{H}\right\}$ NMR $\left(233 \mathrm{~K}, \mathrm{CD}_{2} \mathrm{Cl}_{2,}\right): \delta 156.8$ (d, $J_{\mathrm{C}-\mathrm{P}}=57.1$, C-P Py), 154.1 (d, JC-P = 15.7, NCH Py), 138.2 (CH Py), 134.6 (d, JC-P $\left.=12.4, C_{o} P h\right), 132.2\left(C_{p} P h\right), 131.5\left(d, J_{C-P}=10.0, C_{o} P h\right), 131.0\left(d, J_{C}\right.$ $\mathrm{p}=7.5, \mathrm{CH} \mathrm{Py}), 130.3\left(\mathrm{~m}, \mathrm{C}_{\mathrm{m}} \mathrm{Ph}\right), 128.8\left(\mathrm{~d}, J_{\mathrm{C}-\mathrm{P}}=44.5, \mathrm{C}_{\mathrm{i}} \mathrm{Ph}\right), 128.0$ $\left(\mathrm{d}, J_{\mathrm{C}-\mathrm{P}}=43.4, \mathrm{C}_{\mathrm{i}} \mathrm{Ph}\right)$, 127.0 (CH Py), $93.6(\mathrm{br},=\mathrm{CH}$ nbd), 82.7 (br, $=\mathrm{CH}$ nbd), $66.6(\mathrm{br},=\mathrm{CH} \mathrm{nbd}), 66.4\left(\mathrm{CH}_{2} \mathrm{nbd}\right), 58.2(\mathrm{br},=\mathrm{CH}$ nbd), 52.7 ( $\mathrm{CH}$ nbd), 52.5 ( $\mathrm{CH}$ nbd). MS (MALDI-Tof, $\mathrm{CH}_{2} \mathrm{Cl}_{2}$, $\mathrm{m} / \mathrm{z}): 458.3\left([\mathrm{M} / 2]^{+}, 100 \%\right) . \Lambda_{\mathrm{M}}\left(\right.$ acetone, $\left.5.0 \times 10^{-4} \mathrm{M}\right)=171 \Omega^{-}$ ${ }^{1} \mathrm{~cm}^{2} \mathrm{~mol}^{-1}$.

$\left[\mathbf{R h C l}(\mathbf{n b d})\left\{\mathbf{P h}_{\mathbf{2}} \mathbf{P}\left(\mathbf{C H}_{2}\right)_{2} \mathbf{P y}\right\}\right]$ (5). A solution of $[\mathrm{Rh}(\mu-\mathrm{Cl})(\mathrm{nbd})]_{2}$ (100 $\mathrm{mg}, 0.217 \mathrm{mmol}$ ) in THF $(5 \mathrm{~mL})$ was slowly added to a stirred solution of $\mathrm{Ph}_{2} \mathrm{P}\left(\mathrm{CH}_{2}\right)_{2} \mathrm{Py}(107 \mathrm{mg}, 0.406 \mathrm{mmol})$ in THF (3 $\mathrm{mL}$ ) at $273 \mathrm{~K}$. The resulting orange solution was stirred for 30 min and then the solvent removed under vacuum. The orange oily residue was triturated with cold $n$-hexane to give an orange solid that was washed with cold n-hexane $(3 \times 3 \mathrm{~mL})$ and dried in vacuo. Yield: $65 \%$. Anal. Calcd. for $\mathrm{C}_{26} \mathrm{H}_{26} \mathrm{ClNPRh}$ : C, 59.84; $\mathrm{H}$, 5.02; N, 2.68. Found: C, 59.58; H, 5.11; N, 2.6o. ${ }^{1} \mathrm{H}$ NMR (195 K, $\left.\mathrm{CD}_{2} \mathrm{Cl}_{2}\right): \delta 8.48\left(\mathrm{~d}, J_{\mathrm{H}-\mathrm{H}}=5.0,1 \mathrm{H}, \mathrm{H}-6 \mathrm{Py}\right), 7.76\left(\mathrm{~m},{ }_{1} \mathrm{H}, \mathrm{H}-4 \mathrm{Py}\right)$, 7.56-7.39 (m 11H, H-3 or H-5 Py and $\mathrm{Ph}), 7.17(\mathrm{~s}, 1 \mathrm{H}, \mathrm{H}-3$ or $\mathrm{H}-5$ Py), 5.09 (br, $2 \mathrm{H},=\mathrm{CH}$ nbd), $3.44(\mathrm{~s}, 2 \mathrm{H}, \mathrm{CH}$ nbd), $3.22(\mathrm{br}, 2 \mathrm{H}$, $=\mathrm{CH}$ nbd), $2.96\left(\mathrm{~m}, 2 \mathrm{H}, \mathrm{CH}_{2}\right), 2.58\left(\mathrm{~m}, 2 \mathrm{H}, \mathrm{CH}_{2}\right), 0.94(\mathrm{~m}, 2 \mathrm{H}$, $\mathrm{CH}_{2}$ nbd). ${ }^{31} \mathrm{P}\left\{{ }^{1} \mathrm{H}\right\}$ NMR $\left(195 \mathrm{~K}, \mathrm{CD}_{2} \mathrm{Cl}_{2}\right): \delta 27.40\left(\mathrm{~d}, J_{\mathrm{P}-\mathrm{Rh}}=168.3\right)$. ${ }^{13} \mathrm{C}\left\{{ }^{1} \mathrm{H}\right\}$ NMR (195 K, $\left.\mathrm{CD}_{2} \mathrm{Cl}_{2}\right): \delta 160.9\left(\mathrm{~d}, J_{\mathrm{C}-\mathrm{P}}=4.5, \mathrm{Py}\right), 149.8$ (NCH Py), 136.9, (CH Py), 134.2 (CH Py), 133.1 (d, J-P = 10.7, $\mathrm{C}_{\mathrm{o}}$ $\mathrm{Ph}), 131.6\left(\mathrm{~d}, J_{\mathrm{C}-\mathrm{P}}=40.8, \mathrm{C}_{\mathrm{i}} \mathrm{Ph}\right), 130.1\left(\mathrm{C}_{\mathrm{p}} \mathrm{Ph}\right), 128.4\left(\mathrm{~d}, J_{\mathrm{C}-\mathrm{P}}=9.6\right.$, 
$\mathrm{C}_{\mathrm{m}} \mathrm{Ph}$ ), 121.0 (CH Py), 86.3 (br, =CH nbd), 66.7 (br, =CH nbd), $63.7\left(\mathrm{CH}_{2} \mathrm{nbd}\right), 50.8\left(\mathrm{CH}\right.$ nbd), $29.7\left(\mathrm{~d}, J_{\mathrm{C}-\mathrm{P}}=10.7, \mathrm{CH}_{2}\right), 25.8(\mathrm{~d}$, $\left.J_{\mathrm{C}-\mathrm{P}}=24.2, \mathrm{CH}_{2} \mathrm{P}\right)$. MS (MALDI-Tof, $\left.\mathrm{CH}_{2} \mathrm{Cl}_{2}, \mathrm{~m} / \mathrm{z}, \%\right): 486.0([\mathrm{M}-$ $\left.\mathrm{Cl}]^{+}, 100\right)$.

$\left[\mathbf{R h}(\mathbf{n b d})\left\{\mathbf{P h}_{\mathbf{2}} \mathbf{P}\left(\mathbf{C H}_{\mathbf{2}}\right)_{2} \mathbf{P y}\right\}\right]\left[\mathbf{B F}_{4}\right] \quad(\mathbf{6}){ }^{43} \mathrm{AgBF}_{4}(84.5 \mathrm{mg}, \quad 0.434$ $\mathrm{mmol})$ was added to a suspension of $[\mathrm{Rh}(\mu-\mathrm{Cl})(\mathrm{nbd})]_{2}(100 \mathrm{mg}$, $0.217 \mathrm{mmol}$ ) in THF (10 $\mathrm{mL}$ ). The resulting suspension was stirred for $30 \mathrm{~min}$ and the formed $\mathrm{AgCl}$ removed by filtration to give a pale yellow solution. The solution was concentrated under vacuum to ca. $5 \mathrm{~mL}$ and then cooled to $273 \mathrm{~K}$. The slow addition of a solution of $\mathrm{Ph}_{2} \mathrm{P}\left(\mathrm{CH}_{2}\right)_{2} \mathrm{Py}(126 \mathrm{mg}, 0.434 \mathrm{mmol})$ in THF gave an orange solution which was concentrated under vacuum to 0.5 $\mathrm{mL}$. The slow addition of diethyl ether $(5 \mathrm{~mL})$ gave the compound as an orange microcrystalline solid that was filtered, washed with diethyl ether $(3 \times 2 \mathrm{~mL})$ and dried in vacuo. Yield: 71 \%. Full NMR data: ${ }^{1} \mathrm{H}$ RMN $\left(298 \mathrm{~K}, \mathrm{CD}_{2} \mathrm{Cl}_{2}\right): \delta 8.25\left(\mathrm{~d}, J_{\mathrm{H}-\mathrm{H}}=5.3\right.$, $\left.{ }_{1} \mathrm{H}, \mathrm{H}-6 \mathrm{Py}\right), 7.81\left(\mathrm{td}, J_{\mathrm{H}-\mathrm{H}}=7.7, J_{\mathrm{H}-\mathrm{H}}=1.6,1 \mathrm{H}, \mathrm{H}-4\right.$ Py), $7.48(\mathrm{~m}$, ${ }_{11 \mathrm{H}}$; H-3 or H-5 Py and $\left.\mathrm{Ph}\right), 7.39\left(\mathrm{~m},{ }_{1} \mathrm{H}, \mathrm{H}-3\right.$ or H-5 Py), 5.45 (br, $2 \mathrm{H},=\mathrm{CH}$ nbd), 4.05 (s, 2H, CH nbd), $3.72(\mathrm{~m}, 3 \mathrm{H} ; 2 \mathrm{H}=\mathrm{CH}$ nbd, $\left.{ }_{1} \mathrm{H} \mathrm{CH}{ }_{2} \mathrm{~N}\right), 3.65\left(\mathrm{~m},{ }_{1} \mathrm{H}, \mathrm{CH}_{2} \mathrm{~N}\right), 2.37\left(\mathrm{~m}, 2 \mathrm{H}, \mathrm{CH}_{2} \mathrm{P}\right), 1.58(\mathrm{~s}, 2 \mathrm{H}$, $\mathrm{CH}_{2}$ nbd). ${ }^{31} \mathrm{P}\left\{{ }^{1} \mathrm{H}\right\} \mathrm{RMN}\left(298 \mathrm{~K}, \mathrm{CD}_{2} \mathrm{Cl}_{2}\right): \delta 30.29\left(\mathrm{~d}, J_{\mathrm{P}-\mathrm{Rh}}=167.5\right)$. ${ }^{13} \mathrm{C}\left\{{ }^{1} \mathrm{H}\right\}$ RMN $\left(298 \mathrm{~K}, \mathrm{CD}_{2} \mathrm{Cl}_{2}\right): \delta 161.1\left(\mathrm{~d}, J_{\mathrm{C}-\mathrm{P}}=4.5\right.$, Py), $150.9(\mathrm{NCH}$ Py), 140.7 (CH Py), 133.0 (d, $\left.J_{\mathrm{C}-\mathrm{P}}=11.7, \mathrm{C}_{\mathrm{o}} \mathrm{Ph}\right), 131.8$ (d, $J_{\mathrm{C}-\mathrm{P}}=\mathbf{2 . 4}$, $\left.\mathrm{C}_{\mathrm{p}} \mathrm{Ph}\right), 131.2\left(\mathrm{~d}, J_{\mathrm{C}-\mathrm{P}}=46.0, \mathrm{C}_{\mathrm{i}} \mathrm{Ph}\right), 129.8\left(\mathrm{~d}, J_{\mathrm{C}-\mathrm{P}}=10.4, \mathrm{C}_{\mathrm{m}} \mathrm{Ph}\right)$, 92.3 (br, $=\mathrm{CH}$ nbd), $66.9\left(\mathrm{~d}, J_{\mathrm{C}-\mathrm{Rh}}=4.5, \mathrm{CH}_{2} \mathrm{nbd}\right), 63.30(\mathrm{br},=\mathrm{CH}$ nbd), $53.7(\mathrm{CH} n b d), 38.2\left(\mathrm{~d}, \mathrm{~J}_{\mathrm{C}-\mathrm{P}}=8.6, \mathrm{CH}_{2}\right), 22.7\left(\mathrm{~d}, \mathrm{~J}_{\mathrm{C}-\mathrm{P}}=27.3\right.$, $\mathrm{CH}_{2} \mathrm{P}$ ). MS (MALDI-Tof, matriz DCTB, $\mathrm{CH}_{2} \mathrm{Cl}_{2}, \mathrm{~m} / \mathrm{z}, \%$ ): 487.1 $\left([\mathrm{M}+\mathrm{H}]^{+}, 100\right)$.

$\left[\mathbf{R h}(\mathbf{n b d})\left(\right.\right.$ iPrNH $\left.\left._{2}\right)\left(\mathbf{P h}_{2} \mathbf{P P y}\right)\right]\left[\mathrm{BF}_{4}\right] \quad$ (7). $i \mathrm{PrNH}_{2} \quad(9.46 \mu \mathrm{L}, \quad 0.110$ $\mathrm{mmol})$ was added to a violet solution of $[\mathrm{Rh}(\mathrm{nbd})(\mu-$ $\left.\left.\mathrm{Ph}_{2} \mathrm{PPy}\right)\right]_{2}\left[\mathrm{BF}_{4}\right]_{2}(4)(60 \mathrm{mg}, 0.055 \mathrm{mmol})$ in THF $(5 \mathrm{~mL})$ at $273 \mathrm{~K}$ to give immediately a yellow solution that was stirred for $30 \mathrm{~min}$. The solvent was removed under vacuum to give a yellow solid that was washed with diethyl ether $(3 \times 3 \mathrm{~mL})$ and dried in vacuo. Yield: $67 \%$. Anal. Calcd. for $\mathrm{C}_{27} \mathrm{H}_{31} \mathrm{BF}_{4} \mathrm{~N}_{2} \mathrm{PRh}$ : $\mathrm{C}$, 53.67; $\mathrm{H}, 5.17$; $\mathrm{N}, 4.64$. Found: $\mathrm{C}, 53.82 ; \mathrm{H}, 5.10 ; \mathrm{N}, 4.72 .{ }^{1} \mathrm{H}$ NMR $\left(195 \mathrm{~K}, \mathrm{CD}_{2} \mathrm{Cl}_{2}\right)$ : $\delta 8.62\left(\mathrm{~d}, J_{\mathrm{H}-\mathrm{H}}=4.6,{ }_{1} \mathrm{H}, \mathrm{H}-6 \mathrm{Py}\right), 7.76(\mathrm{~m}, 1 \mathrm{H}, \mathrm{H}-4 \mathrm{Py}), 7.47(\mathrm{~m}$, ${ }_{11} \mathrm{H} ; \mathrm{H}-3$ or $\mathrm{H}-5$ Py and $\left.\mathrm{Ph}\right), 7.34(\mathrm{~m}, 1 \mathrm{H}, \mathrm{H}-3$ or $\mathrm{H}-5 \mathrm{Py}), 5.33$ (br, $2 \mathrm{H}$, =CH nbd), 4.32 (br, $2 \mathrm{H}, \mathrm{NH}_{2}$ ), 3.86 (br, $2 \mathrm{H},=\mathrm{CH}$ nbd), 3.21 (br, $2 \mathrm{H}, \mathrm{CH}$ nbd), 2.51 (br, $1 \mathrm{H}, \mathrm{CH}), 1.36\left(\mathrm{~m}, 2 \mathrm{H}, \mathrm{CH}_{2} \mathrm{nbd}\right), 1.10(\mathrm{~d}$, $\left.J_{\mathrm{H}-\mathrm{H}}=5.1,6 \mathrm{H}, \mathrm{CH}_{3}\right) .{ }^{31} \mathrm{P}\left\{{ }^{1} \mathrm{H}\right\} \mathrm{NMR}\left(195 \mathrm{~K}, \mathrm{CD}_{2} \mathrm{Cl}_{2}\right): \delta 26.65\left(\mathrm{~d}, J_{\mathrm{P}-\mathrm{Rh}}\right.$ $=172.6) .{ }^{13} \mathrm{C}\left\{{ }^{1} \mathrm{H}\right\}$ NMR $\left(195 \mathrm{~K}, \mathrm{CD}_{2} \mathrm{Cl}_{2}\right) \delta 157.2\left(\mathrm{~d}, J_{\mathrm{C}-\mathrm{P}}=62.3, \mathrm{C}-\mathrm{P}\right.$ Py), 150.0 (d, JC-P $=18.5$, NCH Py), $137.1(\mathrm{CH}$ Py), 133.7 (d, JC-P $=$ 12.4, $\left.\mathrm{C}_{\mathrm{o}} \mathrm{Ph}\right), 131.1\left(\mathrm{C}_{\mathrm{p}} \mathrm{Ph}\right), 128.9\left(\mathrm{~d}, J_{\mathrm{C}-\mathrm{P}}=10.7, \mathrm{C}_{\mathrm{m}} \mathrm{Ph}\right)$, $128.0(\mathrm{CH}$ Py), $127.8\left(\mathrm{~d}, J_{\mathrm{C}-\mathrm{P}}=43.6, \mathrm{C}_{\mathrm{i}} \mathrm{Ph}\right.$ ), 125.0 ( $\left.\mathrm{CH} \mathrm{Py}\right), 85.3(\mathrm{br},=\mathrm{CH}$ nbd), $65.4\left(\mathrm{CH}_{2} \mathrm{nbd}\right), 59.8(\mathrm{br},=\mathrm{CH}$ nbd), $52.0(\mathrm{CH} \mathrm{nbd})$, 46.o $(\mathrm{CH})$, $24.9\left(\mathrm{CH}_{3}\right)$. MS (MALDI-Tof, $\left.\mathrm{CH}_{2} \mathrm{Cl}_{2}, \mathrm{~m} / \mathrm{z}, \%\right)$ : 458.1 ([M$\left.\left.i \mathrm{PrNH}_{2}\right]^{+}, 100 \%\right) . \Lambda_{\mathrm{M}}$ (acetone, $\left.5.0 \times 10^{-4} \mathrm{M}\right)=98 \Omega^{-1} \mathrm{~cm}^{2} \mathrm{~mol}^{-1}$.

Reaction of $\left[\mathrm{Rh}(\operatorname{cod})\left(\mathrm{Ph}_{2} \mathrm{PPy}\right)\right]\left[\mathrm{BF}_{4}\right]$ (3) with $\mathrm{iPrNH}_{2}$. a) An NMR tube was charged with a solution of $\left[\mathrm{Rh}(\mathrm{cod})\left(\mathrm{Ph}_{2} \mathrm{PPy}\right)\right]\left[\mathrm{BF}_{4}\right]$ (3) (15 mg, $\left.0.027 \mathrm{mmol}\right)$ in $\mathrm{CD}_{2} \mathrm{Cl}_{2}$ (o.5 $\mathrm{mL}$ ) and then cooled to $273 \mathrm{~K}$. The addition of 1 molar equiv of $i \mathrm{PrNH}_{2}(2.3 \mu \mathrm{L}, 0.027 \mathrm{mmol})$ resulted in the formation of a yellow solution of compound $\left[\mathrm{Rh}(\mathrm{cod})\left(i \mathrm{PrNH}_{2}\right)\left(\mathrm{Ph}_{2} \mathrm{PPy}\right)\right]^{+}(\mathbf{8})$. NMR data: ${ }^{1} \mathrm{H}$ NMR $\left(195 \mathrm{~K}, \mathrm{CD}_{2} \mathrm{Cl}_{2}\right): \delta 8.77\left(\mathrm{~d}, J=4.1,{ }_{1} \mathrm{H}, \mathrm{H}-6 \mathrm{Py}\right)$, $7.83(\mathrm{~m}, 1 \mathrm{H}, \mathrm{H}-4 \mathrm{Py}), 7.47(\mathrm{~m}, 11 \mathrm{H}$; H-3 or $\mathrm{H}-5 \mathrm{Py}$ and $\mathrm{Ph}), 7.38$ (m, $1 \mathrm{H}, \mathrm{H}-3$ or $\mathrm{H}-5 \mathrm{Py}), 5.18(\mathrm{br}, 2 \mathrm{H},=\mathrm{CH} \operatorname{cod}), 4.39(\mathrm{br}, 2 \mathrm{H}$, $=\mathrm{CH}_{2}$ cod $), 3.35\left(\mathrm{~m}, 3 \mathrm{H} ; 2 \mathrm{H} \mathrm{NH}_{2}, 1 \mathrm{H} \mathrm{CH}\right), 2.40-2.33\left(\mathrm{~m}, 8 \mathrm{H}, \mathrm{CH}_{2}\right.$ cod), $1.07\left(\mathrm{~d}, J_{\mathrm{H}-\mathrm{H}}=3.5,6 \mathrm{H}, \mathrm{CH}_{3}\right) .{ }^{31} \mathrm{P}\left\{{ }^{1} \mathrm{H}\right\}$ NMR $\left(195 \mathrm{~K}, \mathrm{CD}_{2} \mathrm{Cl}_{2}\right): \delta$ $21.6\left(\mathrm{~d}, J_{\mathrm{P}-\mathrm{Rh}}=155.4\right) \cdot{ }^{13} \mathrm{C}\left\{{ }^{1} \mathrm{H}\right\}$ NMR $\left(195 \mathrm{~K}, \mathrm{CD}_{2} \mathrm{Cl}_{2}\right): \delta 156.4\left(\mathrm{~d}, J_{\mathrm{C}-\mathrm{P}}\right.$ $=62.3, \mathrm{C}-\mathrm{P}$ Py), 150.2 (d, JC-P $=16.0, \mathrm{NCH}$ Py), $137.3(\mathrm{CH}$ Py), 133.9 $\left(\mathrm{d}, J_{\mathrm{C}-\mathrm{P}}=11.5, \mathrm{C}_{\mathrm{o}} \mathrm{Ph}\right), 131.2\left(\mathrm{C}_{\mathrm{p}} \mathrm{Ph}\right), 128.8\left(\mathrm{~d}, J_{\mathrm{C}-\mathrm{P}}=9.9, \mathrm{C}_{\mathrm{m}} \mathrm{Ph}\right)$, 128.4 (CH Py), 127.9 (d, J $\left.J_{\text {- } P}=41.6, C_{i} P h\right), 125.3(\mathrm{CH} \mathrm{Py}), 102.3(\mathrm{br}$, $=\mathrm{CH} \operatorname{cod}), 77.4\left(\mathrm{~d}, J_{\mathrm{C}-\mathrm{P}}=10.8,=\mathrm{CH} \operatorname{cod}\right), 45.72(\mathrm{CH})$, $30.0\left(\mathrm{CH}_{2}\right.$ cod), $27.5\left(\mathrm{CH}_{2} \mathrm{cod}\right), 24.6\left(\mathrm{CH}_{3}\right)$. b) An NMR tube was charged with a solution of $\left[\mathrm{Rh}(\mathrm{cod})\left(\mathrm{Ph}_{2} \mathrm{PPy}\right)\right]\left[\mathrm{BF}_{4}\right](3)(15 \mathrm{mg}, \quad 0.027$ $\mathrm{mmol}$ ) in $\mathrm{CD}_{2} \mathrm{Cl}_{2}(0.5 \mathrm{~mL})$ and then cooled to $273 \mathrm{~K}$. The addition of 2 molar equiv of $i \mathrm{PrNH}_{2}(2.3 \mu \mathrm{L}, 0.027 \mathrm{mmol})$ resulted in the formation of a yellow solution of compound $\left[\mathrm{Rh}(\mathrm{cod})\left(i \mathrm{PrNH}_{2}\right)_{2}\left(\mathrm{Ph}_{2} \mathrm{PPy}\right)\right]^{+}$(9). NMR data: ${ }^{1} \mathrm{H}$ NMR $(220 \mathrm{~K}$, $\left.\mathrm{CD}_{2} \mathrm{Cl}_{2}\right)$ : broad signals; ${ }^{1} \mathrm{H}$ NMR $\left(220 \mathrm{~K}, \mathrm{THF}-d_{8,}, 243 \mathrm{~K}\right): \delta 8.83(\mathrm{~d}$, $J=4.3,1 \mathrm{H}, \mathrm{H}-6 \mathrm{Py}), 8.33(\mathrm{dd}, J=6.7,6.0,1 \mathrm{H}, \mathrm{Ph}), 8.02(\mathrm{~m}, 5 \mathrm{H}, \mathrm{H}-$ Py and $\mathrm{Ph}), 7.74(\mathrm{~m}, 2 \mathrm{H}, \mathrm{H}-\mathrm{Py}$ and $\mathrm{Ph}), 7.53(\mathrm{~m}, 4 \mathrm{H}, \mathrm{Ph}), 4.06$ (br, $2 \mathrm{H},=\mathrm{CH} \operatorname{cod}), 3.33\left(\mathrm{br}, 2 \mathrm{H},=\mathrm{CH}_{2} \operatorname{cod}\right), 2.98(\mathrm{br}, 2 \mathrm{H}, \mathrm{NH})$, $2.75(\mathrm{~m}, 2 \mathrm{H}, \mathrm{CH}-\mathrm{iPr}), 2.42\left(\mathrm{~m}, 4 \mathrm{H}, \mathrm{CH}_{2} \operatorname{cod}\right), 1.88\left(\mathrm{~m},{ }_{4} \mathrm{H}, \mathrm{CH}_{2}\right.$ cod), 1.36 (d, $\left.J=6.4,12 \mathrm{H}, \mathrm{CH}_{3}-\mathrm{PPr}\right) ;{ }^{31} \mathrm{P}\left\{{ }^{1} \mathrm{H}\right\}$ NMR (195 K, $\left.\mathrm{CD}_{2} \mathrm{Cl}_{2}\right): \delta$ 22.5 (br).

$\left[\mathrm{Rh}_{2}(\operatorname{cod})_{2}\left(\mu-\mathrm{Ph}_{2} \mathbf{P P y}\right)(\boldsymbol{\mu}-\mathrm{C} \equiv \mathbf{C P h})\right]\left[\mathrm{BF}_{4}\right]$ (10). An orange solution of $\left[\mathrm{Rh}(\mathrm{cod})\left(\mathrm{Ph}_{2} \mathrm{PPy}\right)\right]\left[\mathrm{BF}_{4}\right](3)(40 \mathrm{mg}, 0.071 \mathrm{mmol})$ in THF $(4 \mathrm{~mL})$ was treated with phenylacetylene $(19.6 \mu \mathrm{L}, 0.178 \mathrm{mmol})$ to give immediately a red solution that was stirred for $30 \mathrm{~min}$. The solvent was removed under vacuum to give a red oily residue that was triturated with cold diethyl ether to give a red solid. The solid was isolated by filtration and then dissolved in dichloromethane $(1 \mathrm{~mL})$. The solution was layered with diethyl ether $(4 \mathrm{~mL})$ and cooled at $243 \mathrm{~K}$. After $12 \mathrm{~h}$ a dark brown solid was formed which was separated by filtration. The obtained solution was brought to dryness under vacuum and the residue disaggregated by stirring with cold diethyl ether to give the compound as a red solid that was filtered, washed with diethyl ether and dried in vacuo. Yield: 40\%. Anal. Calcd. for $\mathrm{C}_{41} \mathrm{H}_{43} \mathrm{BF}_{4} \mathrm{NPRh}_{2}$ : C, 56.38; H, 4.96; N, 1.6o. Found: $\mathrm{C}$, 55.97; $\mathrm{H}$, 4.87; N, 1.58. ${ }^{1} \mathrm{H}$ NMR $\left(298 \mathrm{~K}, \mathrm{CD}_{2} \mathrm{Cl}_{2}\right): \delta 9.01\left(\mathrm{~d}, J_{\mathrm{H}-\mathrm{H}}=5.3,1 \mathrm{H}, \mathrm{H}-\right.$ 6 Py), 7.76 (m, $1 \mathrm{H}, \mathrm{H}-4$ Py), 7.62-7.52 (m, $\left.{ }_{15} \mathrm{H} \mathrm{Ph}\right), 7.44(\mathrm{~m}, 1 \mathrm{H}, \mathrm{H}-$ 3 or H-5 Py), $7.09(\mathrm{~m}, 1 \mathrm{H}, \mathrm{H}-3$ or $\mathrm{H}-5 \mathrm{Py}), 6.15(\mathrm{br}, 1 \mathrm{H}, \mathrm{H} 1=\mathrm{CH}$ cod), $5.50\left(\mathrm{br}, 1 \mathrm{H}, \mathrm{H}_{2}=\mathrm{CH}\right.$ cod), $5.33\left(\mathrm{br}, 1 \mathrm{H}, \mathrm{H}_{3}=\mathrm{cod}\right), 4.71(\mathrm{br}$, $\left.1 \mathrm{H}, \mathrm{H}_{4}=\mathrm{cod}\right), 4.53\left(\mathrm{br}, 1 \mathrm{H}, \mathrm{H}_{5}=\mathrm{CH}\right.$ cod $), 4.41\left(\mathrm{br},{ }_{1} \mathrm{H}, \mathrm{H} 6=\mathrm{CH}\right.$ cod), 4.13 (br, $1 \mathrm{H}, \mathrm{H} 7=\mathrm{CH}$ cod), 3.09 (br, $1 \mathrm{H}, \mathrm{H} 8=\mathrm{CH}$ cod), 2.822.23 (m, 8H, $\mathrm{CH}_{2}$ cod), 2.09-1.86 (m, 8H, $\mathrm{CH}_{2}$ cod). ${ }^{31} \mathrm{P}\left\{{ }^{1} \mathrm{H}\right\} \mathrm{NMR}$ $\left(298 \mathrm{~K}, \mathrm{CD}_{2} \mathrm{Cl}_{2}\right): \delta 19.14\left(\mathrm{~d}, J_{\mathrm{P}-\mathrm{Rh}}=148.3\right) \cdot{ }^{13} \mathrm{C}\left\{{ }^{1} \mathrm{H}\right\}$ NMR $(298 \mathrm{~K}$, $\left.\mathrm{CD}_{2} \mathrm{Cl}_{2}\right): \delta 163.2\left(\mathrm{~d}, J_{\mathrm{C}-\mathrm{P}}=59.9, \mathrm{C}-\mathrm{P} \mathrm{Py}\right), 152.7\left(\mathrm{~d}, J_{\mathrm{C}-\mathrm{P}}=14.3, \mathrm{CH}\right.$ Py), $138.6\left(\mathrm{~d}, J_{\mathrm{C}-\mathrm{P}}=4.7, \mathrm{CH}\right.$ Py), $134.9\left(\mathrm{~d}, J_{\mathrm{C}-\mathrm{P}}=12.0, \mathrm{C}_{\mathrm{o}} \mathrm{Ph}\right), 133.8$ $\left(\mathrm{d}, J_{\mathrm{C}-\mathrm{P}}=11.9, \mathrm{C}_{\mathrm{o}} \mathrm{Ph}\right), 133.1\left(\mathrm{~d}, J_{\mathrm{C}-\mathrm{P}}=40.5, \mathrm{C}_{\mathrm{i}} \mathrm{Ph}\right), 132.7\left(\mathrm{~d}, J_{\mathrm{C}-\mathrm{P}}=\mathbf{2 . 2}\right.$, $\left.\mathrm{C}_{\mathrm{p}} \mathrm{Ph}\right), 132.5\left(\mathrm{C}_{\mathrm{o}}, \mathrm{Ph}\right.$ alkynyl), $132.0\left(\mathrm{~d}, J_{\mathrm{C}-\mathrm{P}}=2.1, \mathrm{C}_{\mathrm{p}} \mathrm{Ph}\right), 131.6(\mathrm{~d}$, $\left.J_{C-P}=9.0, C H ~ P y\right), 130.3\left(d, J_{C-P}=9.9, C_{m} P h\right), 129.8\left(d, J_{C-P}=9.9\right.$, $\left.\mathrm{C}_{\mathrm{m}} \mathrm{Ph}\right), 129.8\left(\mathrm{~d}, J_{\mathrm{C}-\mathrm{P}}=38.49, \mathrm{C}_{\mathrm{i}} \mathrm{Ph}\right)$, $129.2\left(\mathrm{C}_{\mathrm{p}}\right.$ alkynyl $)$, 129.0 $\left(\mathrm{C}_{\mathrm{i}}\right.$, $\mathrm{Ph}$ alkynyl), 128.7 ( $\mathrm{C}_{\mathrm{m}}$ alkynyl $), 126.1(\mathrm{CH} \mathrm{Py}), 103.5(\mathrm{C} \equiv \mathrm{CPh})$, $101.8\left(\mathrm{ft}, J_{\mathrm{C}-\mathrm{Rh}} \approx J_{\mathrm{C}-\mathrm{P}}=7.9, \mathrm{C} 1=\mathrm{CH} \operatorname{cod}\right), 96.7\left(\mathrm{dd}, J_{\mathrm{C}-\mathrm{Rh}}=14.2, J_{\mathrm{C}-\mathrm{P}}=\right.$ 7.0, $\left.\mathrm{C}_{4}=\mathrm{CH} \operatorname{cod}\right), 94.4\left(\mathrm{~d}, J_{\mathrm{C}-\mathrm{Rh}}=7.5, \mathrm{C}_{2}=\mathrm{CH} \operatorname{cod}\right), 93.9\left(\mathrm{~d}, J_{\mathrm{C}-\mathrm{Rh}}=\right.$ 7.9, $\left.\mathrm{C}_{7}=\mathrm{CH} \operatorname{cod}\right)$, 92.2 $\left(\mathrm{d}, J_{\mathrm{C}-\mathrm{Rh}}=14.0, \mathrm{C} 6=\mathrm{CH} \operatorname{cod}\right)$, $90.1\left(\mathrm{~d}, J_{\mathrm{C}-\mathrm{Rh}}\right.$ $=11.0, \mathrm{C}_{5}=\mathrm{CH}$ cod $), 85.4\left(\mathrm{~d}, J_{\mathrm{C}-\mathrm{Rh}}=10.2, \mathrm{C}_{3}=\mathrm{CH} \operatorname{cod}\right), 81.5\left(\mathrm{~d}, J_{\mathrm{C}-}\right.$ $\mathrm{Rh}=11.6, \mathrm{C} 8=\mathrm{CH} \operatorname{cod}), 34.3\left(\mathrm{~d}, J_{\mathrm{C}-\mathrm{Rh}}=3.8, \mathrm{CH}_{2} \operatorname{cod}\right)$, $33.0\left(\mathrm{CH}_{2}\right.$ cod), $31.6\left(\mathrm{~d}, J_{\mathrm{C}-\mathrm{Rh}}=1.6, \mathrm{CH}_{2} \mathrm{cod}\right), 31.4\left(\mathrm{CH}_{2} \mathrm{cod}\right), 31.3\left(\mathrm{CH}_{2} \mathrm{cod}\right)$, 31.0 $\left(\mathrm{CH}_{2} \operatorname{cod}\right), 29.3\left(\mathrm{~d}, J_{\mathrm{C}-\mathrm{Rh}}=1.5, \mathrm{CH}_{2} \operatorname{cod}\right), 28.7\left(\mathrm{~d}, J_{\mathrm{C}-\mathrm{Rh}}=\mathbf{2 . 4}\right.$, $\mathrm{CH}_{2}$ cod) ( $\mathrm{C} \equiv \mathrm{CPh}$ not observed). MS (MALDI-Tof, acetone, $\mathrm{m} / \mathrm{z}$, $\%): 786.1\left(\left[\mathrm{M}^{+}\right], 100\right) . \Lambda_{\mathrm{M}}$ (acetone, $\left.5.0 \times 10^{-4} \mathrm{M}\right)=115 \Omega^{1} \mathrm{~cm}^{2} \mathrm{~mol}^{-1}$.

Scheme 9. Numbering scheme for NMR data of compounds 10 and 11.

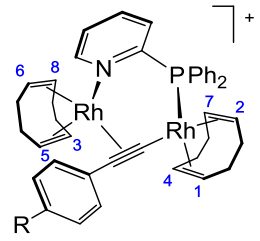


$\left[\mathrm{Rh}_{2}(\operatorname{cod})_{2}\left(\boldsymbol{\mu}-\mathrm{Ph}_{2} \mathrm{PPy}\right)\left(\boldsymbol{\mu}-\mathrm{C} \equiv \mathrm{C}-\mathrm{C}_{6} \mathrm{H}_{5}-\mathbf{t B u}\right)\right]\left[\mathrm{BF}_{4}\right]$ (11). The compound was obtained as a red solid from $\left[\mathrm{Rh}(\mathrm{cod})\left(\mathrm{Ph}_{2} \mathrm{PPy}\right)\right]\left[\mathrm{BF}_{4}\right]$ (3) (40 mg, o.071 mmol) and 1-ter-butil-phenylacetylene $(32 \mu \mathrm{L}$, $0.18 \mathrm{mmol}$ ) following the procedure described above for 9. Yield: $32 \%$. Anal. Calcd. for $\mathrm{C}_{44} \mathrm{H}_{51} \mathrm{BF}_{4} \mathrm{NPRh}_{2}$ : C, 57.6o; H, 5.6o; N, 1.53 . Found: $\mathrm{C}$, 58.02; $\mathrm{H}, 5.53 ; \mathrm{N}, 1.50 .{ }^{1} \mathrm{H}$ NMR $\left(298 \mathrm{~K}, \mathrm{CD}_{2} \mathrm{Cl}_{2}\right): \delta 9.01$ $\left(\mathrm{d}, J_{\mathrm{H}-\mathrm{H}}=5.1,1 \mathrm{H}, \mathrm{H}-6 \mathrm{Py}\right), 7.77(\mathrm{tt}, 1 \mathrm{H}, \mathrm{H}-4 \mathrm{Py}), 7.71-7.52(\mathrm{~m}, 10 \mathrm{H}$, $\mathrm{Ph}), 7.44(\mathrm{~m}, 1 \mathrm{H}, \mathrm{H}-3$ or $\mathrm{H}-5 \mathrm{Py}), 7.42-7.39(\mathrm{~m}, 5 \mathrm{H}, \mathrm{Ph}), 7.09(\mathrm{~m}$, ${ }_{1} \mathrm{H}, \mathrm{H}-3$ or $\mathrm{H}-5 \mathrm{Py}$ ), 6.13 (br, $1 \mathrm{H}, \mathrm{H} 1=\mathrm{CH}$ cod), 5.48 (br, $1 \mathrm{H}, \mathrm{H} 2$ $=\mathrm{CH}$ cod), $5.35\left(\mathrm{br}, 1 \mathrm{H}, \mathrm{H}_{3}=\mathrm{CH}\right.$ cod), $4.7 \mathrm{O}\left(\mathrm{br}, 1 \mathrm{H}, \mathrm{H}_{4}=\mathrm{CH} \operatorname{cod}\right)$, 4.55 (br, $1 \mathrm{H}, \mathrm{H}_{5}=\mathrm{CH}$ cod), 4.37 (br, $1 \mathrm{H}, \mathrm{H} 6=\mathrm{CH}$ cod), 4.10 (br, ${ }_{1} \mathrm{H}, \mathrm{H}_{7}=\mathrm{CH}$ cod), $3.09\left(\mathrm{br},{ }_{1} \mathrm{H}, \mathrm{H} 8=\mathrm{CH} \operatorname{cod}\right), 2.75^{-1.79}(\mathrm{~m}, 16 \mathrm{H}$, $\left.\mathrm{CH}_{2} \operatorname{cod}\right), 1.34(\mathrm{~s}, 9 \mathrm{H}, t \mathrm{Bu}) .{ }^{31} \mathrm{P}\left\{{ }^{1} \mathrm{H}\right\}$ NMR $\left(298 \mathrm{~K}, \mathrm{CD}_{2} \mathrm{Cl}_{2}\right): \delta 19.22$ $\left(\mathrm{d}, J_{\mathrm{P}-\mathrm{Rh}}=148.2\right) .{ }^{13} \mathrm{C}\left\{{ }^{1} \mathrm{H}\right\}$ NMR $\left(298 \mathrm{~K}, \mathrm{CD}_{2} \mathrm{Cl}_{2}\right): 163.4$ (C-P Py), 152.7 (d, JC-P $=14.2$, NCH Py), $152.4\left(C_{\mathrm{p}}\right.$, Ph alkynyl), $138.5\left(\mathrm{~d}, J_{\mathrm{C}-\mathrm{P}}=\right.$ 4.5, CH Py), 134.9 (d, J $\left.J_{\text {- } P}=12.2, C_{o} P h\right), 133.8\left(d, J_{C-P}=12.1, C_{o} P h\right)$, $133.2\left(\mathrm{~d}, J_{\mathrm{C}-\mathrm{P}}=40.0, \mathrm{C}_{\mathrm{i}} \mathrm{Ph}\right), 132.7\left(\mathrm{C}_{\mathrm{p}} \mathrm{Ph}\right), 132.4\left(\mathrm{C}_{\mathrm{o}}, \mathrm{Ph}\right.$ alkynyl), $132.0\left(\mathrm{~d}, J_{\mathrm{C}-\mathrm{P}}=1.6, \mathrm{C}_{\mathrm{p}} \mathrm{Ph}\right), 131.6\left(\mathrm{~d}, J_{\mathrm{C}-\mathrm{P}}=8.9, \mathrm{CH} \mathrm{Py}\right), 130.3\left(\mathrm{~d}, J_{\mathrm{C}-\mathrm{P}}\right.$ $\left.=9.9, C_{m} P h\right), 129.8\left(\mathrm{~d}, J_{C-P}=9.8, C_{m} P h\right), 129.6\left(d, J_{C-P}=39.7, C_{i}\right.$ $\mathrm{Ph}),{ }_{126.3}\left(\mathrm{C}_{\mathrm{m}}, \mathrm{Ph}\right.$ alkynyl $), 126.0(\mathrm{CH}$ Py $), 123.1\left(\mathrm{C}_{\mathrm{i}}, \mathrm{Ph}\right.$ alkynyl $)$, $103.8(C \equiv \mathrm{CPh}), 101.8\left(\mathrm{ft}, J_{\mathrm{C}-\mathrm{Rh}} \approx J_{\mathrm{C}-\mathrm{P}}=7.8, \mathrm{C}_{1}=\mathrm{CH} \operatorname{cod}\right), 96.6(\mathrm{dd}$, $\left.J_{\mathrm{C}-\mathrm{Rh}}=14.3, J_{\mathrm{C}-\mathrm{P}}=6.9, \mathrm{C}_{4}=\mathrm{CH} \operatorname{cod}\right), 94.1\left(\mathrm{~d}, J_{\mathrm{C}-\mathrm{Rh}}=7.5, \mathrm{C}_{2}=\mathrm{CH}\right.$ cod), $93.4\left(\mathrm{~d}, J_{\mathrm{C}-\mathrm{Rh}}=8.0, \mathrm{C}_{7}=\mathrm{CH} \operatorname{cod}\right), 91.7\left(\mathrm{~d}, J_{\mathrm{C}-\mathrm{Rh}}=13.8, \mathrm{C} 6\right.$ $=\mathrm{CH} \operatorname{cod})$, $90.2\left(\mathrm{~d}, J_{\mathrm{C}-\mathrm{Rh}}=11.0, \mathrm{C}_{5}=\mathrm{CH} \operatorname{cod}\right), 85.2\left(\mathrm{~d}, J_{\mathrm{C}-\mathrm{Rh}}=10.0\right.$, $\left.\mathrm{C}_{3}=\mathrm{CH} \operatorname{cod}\right), 81.3\left(\mathrm{~d}, J_{\mathrm{C}-\mathrm{Rh}}=11.6, \mathrm{C} 8=\mathrm{CH} \operatorname{cod}\right), 35.4(t \mathrm{Bu}), 34.3$ $\left(\mathrm{CH}_{2} \mathrm{cod}\right)$, 33.0 $\left(\mathrm{CH}_{2} \mathrm{cod}\right)$, 31.7 $\left(\mathrm{CH}_{2} \mathrm{cod}\right)$, 31.7-31.4 (br, $\left.\mathrm{CH}_{2} \mathrm{cod}\right)$, $31.4\left(-\mathrm{CH}_{3}, t \mathrm{Bu}\right)$, 31.0 $\left(\mathrm{CH}_{2} \operatorname{cod}\right)$, $29.4\left(\mathrm{CH}_{2} \operatorname{cod}\right), 28.7\left(\mathrm{CH}_{2} \mathrm{cod}\right)$ (C $\equiv C \mathrm{Ph}$ not observed). MS (MALDI-Tof, $\left.\mathrm{CH}_{2} \mathrm{Cl}_{2}, \mathrm{~m} / \mathrm{z}, \%\right): 830.1$ $\left(\left[\mathrm{M}^{+}\right], 100\right)$.

$\left[\mathbf{R h}_{\mathbf{2}}(\mathbf{n b d})_{\mathbf{2}}\left(\boldsymbol{\mu}-\mathbf{P h}_{\mathbf{2}} \mathbf{P P y}\right)(\boldsymbol{\mu}-\mathbf{C} \equiv \mathbf{C P h})\right]\left[\mathrm{BF}_{4}\right] \quad$ (12). Phenylacetylene (32.2 $\mu \mathrm{L}, 0.293 \mathrm{mmol}$ ) was added to a violet solution of $\left[\mathrm{Rh}(\mathrm{nbd})\left(\mathrm{Ph}_{2} \mathrm{PPy}\right)\right]_{2}\left[\mathrm{BF}_{4}\right]_{2}(4)(8 \mathrm{o} \mathrm{mg}, 0.073 \mathrm{mmol})$ in $\mathrm{CH}_{2} \mathrm{Cl}_{2}(4$ $\mathrm{mL})$ at $273 \mathrm{~K}$ to give a deep red solution. The solution was stirred for $30 \mathrm{~min}$ at $273 \mathrm{~K}$ and then brought to drynes under vacuum. The red oily residue was triturated with cold diethyl ether to give a red solid. The solid was dissolved in acetone $(1 \mathrm{~mL})$ and the solution layered with diethyl ether $(6 \mathrm{~mL})$ and cooled at $243 \mathrm{~K}$ for $12 \mathrm{~h}$. The red solid that crystallized out was filtered, washed with diethyl ether and dried in vacuo. Yield: $40 \%$. Anal. Calcd. for $\mathrm{C}_{39} \mathrm{H}_{35} \mathrm{BF}_{4} \mathrm{NPRh}_{2}$ : C, 55.68; $\mathrm{H}, 4.19 ; \mathrm{N}, 1.66$. Found: $\mathrm{C}, 55.49 ; \mathrm{H}$, 4.07; N, 1.67. ${ }^{1} \mathrm{H}$ NMR $\left(220 \mathrm{~K}, \mathrm{CD}_{2} \mathrm{Cl}_{2}\right): 8.65\left(\mathrm{~d}, J_{\mathrm{H}-\mathrm{H}}=5.2,1 \mathrm{H}, \mathrm{H}-6\right.$ Py), 7.74-7.27 (m, 18H, H-4, H-3 and $\mathrm{H}_{-5} \mathrm{Py}$ and $\mathrm{Ph}$ ), 5.63 (br, $1 \mathrm{H}$, $=\mathrm{CH}$ nbd), 5.13 (br, $1 \mathrm{H},=\mathrm{CH}$ nbd), $4.7 \mathrm{O}(\mathrm{br}, 1 \mathrm{H},=\mathrm{CH}$ nbd), 4.61 (br, $1 \mathrm{H},=\mathrm{CH}$ nbd), 5.16 (br, $2 \mathrm{H},=\mathrm{CH}$ nbd, $\mathrm{CH}$ nbd), $4.05\left(\mathrm{br},{ }_{1} \mathrm{H}\right.$, =CH nbd), 3.95 (br, $1 \mathrm{H}, \mathrm{CH}$ nbd), 3.86 (br, $1 \mathrm{H}, \mathrm{CH}$ nbd), 3.63 (br, $1 \mathrm{H}, \mathrm{CH}$ nbd), 3.53 (br, $1 \mathrm{H},=\mathrm{CH}$ nbd), $2.00(\mathrm{br}, 1 \mathrm{H},=\mathrm{CH}$ nbd), 1.62 $\left(\mathrm{m}, 2 \mathrm{H}, \mathrm{CH}_{2}\right.$ nbd), 1.15 (m, $2 \mathrm{H}, \mathrm{CH}_{2}$ nbd). ${ }^{31} \mathrm{P}\left\{{ }^{1} \mathrm{H}\right\}$ NMR $(22 \mathrm{O} \mathrm{K}$, $\left.\mathrm{CD}_{2} \mathrm{Cl}_{2}\right): \delta 24.26\left(\mathrm{~d}, J_{\mathrm{P}-\mathrm{Rh}}=154.4\right) \cdot{ }^{13} \mathrm{C}\left\{{ }^{1} \mathrm{H}\right\}$ NMR $\left(220 \mathrm{~K}, \mathrm{CD}_{2} \mathrm{Cl}_{2}\right)$ : $162.2\left(\mathrm{~d}, J_{\mathrm{C}-\mathrm{P}}=60.4\right.$, C-P Py), $151.3\left(\mathrm{~d}, J_{\mathrm{C}-\mathrm{P}}=14.5\right.$, NCH Py), $137.6(\mathrm{~d}$, $J_{\mathrm{C}-\mathrm{P}}=4.4, \mathrm{CH}$ Py $), 136.0\left(\mathrm{~d}, J_{\mathrm{C}-\mathrm{P}}=12.6, \mathrm{C}_{\mathrm{o}} \mathrm{Ph}\right), 131.5\left(\mathrm{C}_{\mathrm{o}}, \mathrm{Ph}\right.$ alkynyl), $131.1\left(C_{m}\right.$ Py), $129.8\left(\mathrm{~d}, J_{\mathrm{C}-\mathrm{P}}=10.7, \mathrm{C}_{\mathrm{m}} \mathrm{Ph}\right), 129.6\left(\mathrm{C}_{\mathrm{p}}, \mathrm{Ph}\right)$, $129.4\left(\mathrm{~d}, J_{\mathrm{C}-\mathrm{P}}=9.6, \mathrm{C}_{\mathrm{m}} \mathrm{Ph}\right), 128.7\left(\mathrm{C}_{\mathrm{p}}, \mathrm{Ph}\right.$ alkynyl $), 128.7\left(\mathrm{~d}, J_{\mathrm{C}-\mathrm{P}}=\right.$ 41.5, $\left.C_{\mathrm{i}} \mathrm{Ph}\right), 127.4\left(\mathrm{~d}, J_{\mathrm{C}-\mathrm{P}}=48.6, \mathrm{C}_{\mathrm{i}} \mathrm{Ph}\right), 127.6\left(\mathrm{C}_{\mathrm{m}}, \mathrm{Ph}\right.$ alkynyl), $125.6\left(\mathrm{C}_{\mathrm{m}} \mathrm{Py}\right), 125.4\left(\mathrm{C}_{\mathrm{i}}\right.$, Ph alkynyl), 103.2 $(\mathrm{C} \equiv \mathrm{CPh}), 86.4(\mathrm{br},=\mathrm{CH}$ nbd), 84.3 (br, =CH nbd), $79.6\left(\mathrm{~d}, J_{\mathrm{C}-\mathrm{Rh}}=8.6,=\mathrm{CH}\right.$ nbd), $71.4(\mathrm{~d}$, $J_{\mathrm{C}-\mathrm{Rh}}=7.0,=\mathrm{CH}$ nbd), $69.1\left(\mathrm{CH}_{2}\right.$ nbd), $63.6\left(\mathrm{br},{ }_{2} \mathrm{C}=\mathrm{CH}\right.$ nbd), 63.2 $\left(\mathrm{d}, J_{\mathrm{C}-\mathrm{Rh}}=10.3,=\mathrm{CH} \mathrm{nbd}\right), 61.3\left(\mathrm{CH}_{2} \mathrm{nbd}\right), 53.5(\mathrm{CH} \mathrm{nbd}), 53.2$ ( $\mathrm{CH}$ nbd), 53.2 ( $\mathrm{CH}$ nbd), 51.6 (=CH nbd), 51.4 ( $\mathrm{CH} \mathrm{nbd)} \mathrm{(} \equiv C \mathrm{CPh}$ not observed). MS (MALDI-Tof, $\left.\mathrm{CH}_{2} \mathrm{Cl}_{2}, \mathrm{~m} / \mathrm{z}, \%\right)$ : $754.0\left(\left[\mathrm{M}^{+}\right]\right.$, 100).

Reaction of $\left[\mathrm{Rh}(\operatorname{cod})\left(\mathrm{Ph}_{2} \mathrm{PPy}\right)\right]\left[\mathrm{BF}_{4}\right]$ (3) with $\mathrm{Ph}-\mathrm{C} \equiv \mathrm{CH}$. A solution of $\left[\mathrm{Rh}(\mathrm{cod})\left(\mathrm{Ph}_{2} \mathrm{PPy}\right)\right]\left[\mathrm{BF}_{4}\right](3)(40 \mathrm{mg}, 0.071 \mathrm{mmol})$ in $\mathrm{CH}_{2} \mathrm{Cl}_{2}(4 \mathrm{~mL})$ was treated with phenylacetylene $(7.8 \mu \mathrm{L}, 0.18$ $\mathrm{mmol}$ ) to give a red solution. The solution was stirred for $1 \mathrm{~h}$ and then the solvent was removed in vacuo. The red oily residue was disaggregated by stirring with cold diethyl ether to give a red solid which was isolated by filtration. The spectroscopic data revealed the presence of a mixture of compounds 10 and 13 in a ratio of $3: 7$.

[(cod) $\left.\mathbf{R h}\left(\mathbf{P h}_{2} \mathbf{P C}_{5} \mathbf{H}_{4} \mathbf{N}-\mathbf{C}=\mathbf{C H P h}\right)\right]\left[\mathrm{BF}_{4}\right]$ (13). NMR data: ${ }^{1} \mathrm{H}$ NMR $\left(233 \mathrm{~K}, \mathrm{CD}_{2} \mathrm{Cl}_{2}\right): \delta 9.03\left(\mathrm{~d}, J_{\mathrm{H}-\mathrm{H}}=5.6,1 \mathrm{H}, \mathrm{H}-6 \mathrm{Py}\right), 8.21(\mathrm{t}, 1 \mathrm{H}, \mathrm{H}-4$ Py), $7.99(\mathrm{t}, 1 \mathrm{H}, \mathrm{H}-3$ or H-5 Py), $7.74(\mathrm{~m}, 1 \mathrm{H}, \mathrm{H}-3$ or H-5 Py), $7.68-$ $7.34(\mathrm{~m}, 15 \mathrm{H}, \mathrm{Ph}), 6.96(\mathrm{~s}, 1 \mathrm{H}, \mathrm{C}=\mathrm{CHPh}), 5.63(\mathrm{br}, 1 \mathrm{H},=\mathrm{CH}$ cod), $5.52\left(\mathrm{br}, 1 \mathrm{H},=\mathrm{CH}\right.$ cod), $3.95\left(\mathrm{br}, 1 \mathrm{H},=\mathrm{CH}\right.$ cod), $3.63\left(\mathrm{br},{ }_{1} \mathrm{H},=\mathrm{CH}\right.$ cod), 2.83-1.84 (m, 8H, $\left.\mathrm{CH}_{2} \operatorname{cod}\right) .{ }^{31} \mathrm{P}\left\{{ }^{1} \mathrm{H}\right\} \operatorname{NMR}\left(233 \mathrm{~K}, \mathrm{CD}_{2} \mathrm{Cl}_{2}\right): \delta$ $43.44\left(\mathrm{~d}, J_{\mathrm{P}-\mathrm{Rh}}=183.2\right) .{ }^{13} \mathrm{C}\left\{{ }^{1} \mathrm{H}\right\}$ NMR $\left(233 \mathrm{~K}, \mathrm{CD}_{2} \mathrm{Cl}_{2}\right): 177.6\left(\mathrm{dd}, J_{\mathrm{C}-}\right.$ $\left.\mathrm{Rh}=43.0, J_{\mathrm{C}-\mathrm{P}}=14.6, \mathrm{Rh}-\mathrm{C}=\mathrm{C}\right), 157.5\left(\mathrm{~d}, J_{\mathrm{C}-\mathrm{P}}=46.9\right.$, C-P Py), 143.6 $\left(\mathrm{d}, J_{\mathrm{C}-\mathrm{P}}=2.1, \mathrm{CH}\right.$ Py), $140.0\left(\mathrm{~d}, J_{\mathrm{C}-\mathrm{P}}=4.8, \mathrm{NCH}\right.$ Py $), 138.6(\mathrm{Ph}), 136.1$ (C=CHPh), 130.1 (CH Py), 129.2 (CH Py), 129.7 (d, J $\left.J_{\mathrm{C}-\mathrm{P}}=10.6, \mathrm{Ph}\right)$, 129.0 $(\mathrm{Ph}), 128.6\left(J_{\mathrm{C}-\mathrm{P}}=39.7, \mathrm{Ph}\right), 128.3(\mathrm{Ph}), 128.2(\mathrm{Ph}), 100.5(\mathrm{br}$, $=\mathrm{CH}$ cod), 97.8 (br, =CH cod), 93.7 (br, =CH cod), 91.7 (br, =CH cod), 35.0, 34.6, 27.1, $26.6\left(\mathrm{CH}_{2}\right.$ cod). MS (MALDI-Tof, $\mathrm{CH}_{2} \mathrm{Cl}_{2}$, $\mathrm{m} / \mathrm{z}, \%): 576.1\left([\mathrm{M}]^{+}, 100\right)$.

$\left[\mathbf{R h}\left(\mathrm{Ph}_{2} \mathrm{PPy}_{3}\right]\left[\mathrm{BF}_{4}\right]\right.$ (14). A solution of $\mathrm{Ph}_{2} \mathrm{PPy}$ (59.1 mg, 0.225 $\mathrm{mmol})$ in acetone $(2 \mathrm{~mL})$ was slowly added to a solution of $\left[\mathrm{Rh}(\mathrm{cod})\left(\mathrm{Ph}_{2} \mathrm{PPy}\right)\right]\left[\mathrm{BF}_{4}\right]$ (3) (6o mg, $\left.0.107 \mathrm{mmol}\right)$ in acetone (5 $\mathrm{mL})$ a $273 \mathrm{~K}$ and stirred for $30 \mathrm{~min}$. The resulting yellow solution was brought to dryness to give a yellow solid that was washed with cold diethyl ether $(2 \times 3 \mathrm{~mL})$ and dried in vacuo. The crude compound was recrystallized from dichloromethane/diethyl ether. Yield: $57 \%$. ${ }^{1} \mathrm{H}$ NMR $\left(200 \mathrm{~K}\right.$, acetone- $\left.d_{6}\right): \delta 8.85\left(\mathrm{~d}, J_{\mathrm{H}-\mathrm{H}}=\right.$ 3.9, $1 \mathrm{H}, \mathrm{Py}$ ), 8.66 (br, $1 \mathrm{H}, \mathrm{Py}), 8.49$ (br, $1 \mathrm{H}, \mathrm{Py}), 8.29$ (m, $1 \mathrm{H}, \mathrm{Py})$, $8.12(\mathrm{~m}, 1 \mathrm{H}, \mathrm{Py}), 7.99-7.17(\mathrm{~m}, 36 \mathrm{H}$; $30 \mathrm{Ph}, 6 \mathrm{H} \mathrm{Py}), 6.93(\mathrm{br}, 1 \mathrm{H}$, Py). ${ }^{31} \mathrm{P}\left\{{ }^{1} \mathrm{H}\right\}$ NMR (200 K, acetone- $\left.d_{6}\right): \delta 55.34\left(\mathrm{~d} \mathrm{br}, J_{\mathrm{PB}-\mathrm{Rh}}=132.4\right.$, $\left.\mathrm{P}_{\mathrm{B}}\right), 32.63\left(\mathrm{ddd}, J_{\mathrm{PA}-\mathrm{Pc}}=303.7, J_{\mathrm{PA}-\mathrm{Rh}}=153.1, J_{\mathrm{PA}-\mathrm{PB}}=35.2, \mathrm{P}_{\mathrm{A}}\right),-28.74$ $\left(\mathrm{ddd}, J_{\mathrm{PC}-\mathrm{PA}}=303.7, J_{\mathrm{PC}-\mathrm{Rh}}=123.9, J_{\mathrm{PC}-\mathrm{PB}}=35.2, \mathrm{P}_{\mathrm{C}}\right) .{ }^{13} \mathrm{C}\left\{{ }^{1} \mathrm{H}\right\} \mathrm{NMR}$ $\left(200 \mathrm{~K}\right.$, acetone- $\left.d_{6}\right): \delta 175.9\left(\mathrm{~d}, J_{\mathrm{C}-\mathrm{P}}=50.1, \mathrm{C}-\mathrm{P}\right.$ Py), $156.8(\mathrm{C}-\mathrm{P}$ Py), 155.2 (C-P Py), 151.3 (d, J $J_{\text {- } P}=19.2, \mathrm{NHC}$ Py), 137.5 (d, $J_{\mathrm{C}-\mathrm{P}}=9.2, \mathrm{CH}$ Py), 136.4-128.3 (CH Ph, CH Py, $\mathrm{C}_{\mathrm{i}} \mathrm{Ph}$ ), 126.2 (CH Py), 124.1 (CH Py). HRMS (ESI/ $\mu$ Q-TOF, $\mathrm{CH}_{3} \mathrm{CN}, \mathrm{m} / \mathrm{z}$ ): $\mathrm{M}^{+}$, Calcd for $\mathrm{C}_{51} \mathrm{H}_{42} \mathrm{~N}_{3} \mathrm{P}_{3} \mathrm{Rh}$, 892.1647, Found 892.1633; [M- $\left.\mathrm{Ph}_{2} \mathrm{PPy}\right]^{+}$, Calcd for $\mathrm{C}_{34} \mathrm{H}_{28} \mathrm{~N}_{2} \mathrm{P}_{2} \mathrm{Rh}$ 629.0783, Found 629.0770.

Scheme 10. Ligand labelling for NMR data of compound 14 .

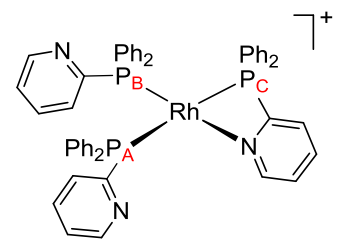

$\left[\mathbf{R h}(\mathbf{C} \equiv \mathbf{C P h})(\mathbf{c o d})\left(\mathbf{P h}_{2} \mathbf{P P y}\right)\right](\mathbf{1 5})$. A solution of $\mathrm{Ph}_{2} \mathrm{PPy}(100 \mathrm{mg}$, $0.380 \mathrm{mmol})$ in diethyl ether $(5 \mathrm{~mL})$ was slowly added to a solution of $[\mathrm{Rh}(\mu-\mathrm{OMe})(\mathrm{cod})]_{2}(92 \mathrm{mg}, 0.19 \mathrm{mmol})$ in diethyl ether $(5$ $\mathrm{mL}$ ). The solution was stirred for $15 \mathrm{~min}$ at room temperature and cooled to $253 \mathrm{~K}$ before adding a solution of $\mathrm{PhC} \equiv \mathrm{CH}(45.9$ $\mu \mathrm{L}, 0.418 \mathrm{mmol})$ in diethyl ether $(2 \mathrm{~mL})$. The mixture was stirred for $40 \mathrm{~min}$ at $273 \mathrm{~K}$ and then filtered. The obtained solution was brought to dryness under vacuum to give a brown solid that was washed with $n$-hexane $(3 \times 3 \mathrm{~mL})$ and dried in vacuo. Yield: $56 \%$. Satisfactory elemental analysis could not be obtained. ${ }^{1} \mathrm{H}$ NMR $\left(220 \mathrm{~K}, \mathrm{CD}_{2} \mathrm{Cl}_{2}\right): \delta 8.70\left(\mathrm{~d}, J_{\mathrm{H}-\mathrm{H}}=3.8,{ }_{1} \mathrm{H}, \mathrm{H}-6 \mathrm{Py}\right), 7.89-7.43(\mathrm{~m}$, $10 \mathrm{H}, \mathrm{Ph}$ ), 7.28-6.94 (m 8H; $5 \mathrm{H}$ Ph alkynyl and $3 \mathrm{H} \mathrm{Py}), 5.65$ (br, $2 \mathrm{H},=\mathrm{CH} \operatorname{cod}), 3.90(\mathrm{br}, 2 \mathrm{H},=\mathrm{CH} \operatorname{cod}), 2.30\left(\mathrm{~m}, \mathrm{CH}_{2} \mathrm{cod}\right), 2.11(\mathrm{~m}$, $\left.\mathrm{CH}_{2} \operatorname{cod}\right) .{ }^{31} \mathrm{P}\left\{{ }^{1} \mathrm{H}\right\}$ NMR $\left(22 \mathrm{~K}, \mathrm{CD}_{2} \mathrm{Cl}_{2}\right): \delta 31.96\left(\mathrm{~d}, J_{\mathrm{P}-\mathrm{Rh}}=161.2\right)$. ${ }^{13} \mathrm{C}\left\{{ }^{1} \mathrm{H}\right\}$ NMR (220 K, $\left.\mathrm{CD}_{2} \mathrm{Cl}_{2}\right): \delta 158.9$ (d, JC-P $=58.7$, C-P Py), 149.8 $\left(\mathrm{d}, J_{\mathrm{C}-\mathrm{P}}=13.1, \mathrm{NHC}\right.$ Py), $138.3\left(\mathrm{C}_{\mathrm{i}}, \mathrm{Ph}\right.$ alkynyl), $135.3\left(\mathrm{~d}, J_{\mathrm{C}-\mathrm{P}}=12.1\right.$, 
$\left.\mathrm{C}_{\mathrm{o}} \mathrm{Ph}\right), 133.3\left(\mathrm{~d}, J_{\mathrm{C}-\mathrm{P}=}\right.$ 43.2, $\left.\mathrm{C}_{\mathrm{i}}, \mathrm{Ph}\right), 130.1\left(\mathrm{C}_{\mathrm{o}}, \mathrm{Ph}\right.$ alkynyl $), 128.7\left(\mathrm{C}_{\mathrm{p}}\right.$ $\mathrm{Ph})$, 128.6 (CH Py), 128.0 (d, J $\left.J_{\text {- } P}=10.1, C_{m} P h\right), 127.7\left(C_{p}, P h\right.$ alkynyl), 127.3 (CH Py), 124.8 ( $\mathrm{C}_{\mathrm{m}}$, Ph alkynyl), 123.7 ( $\mathrm{CH}$ Py), 121.8 $\left(\mathrm{dd}, J_{\mathrm{C}-\mathrm{Rh}}=49.3, J_{\mathrm{C}-\mathrm{P}}=22.1, \mathrm{C} \equiv \mathrm{CPh}\right), 118.3\left(\mathrm{dd}, J_{\mathrm{C}-\mathrm{Rh}}=12.6, J_{\mathrm{C}-\mathrm{P}}<2\right.$ $\mathrm{Hz}, \mathrm{C} \equiv C \mathrm{Ph}), 98.1\left(\mathrm{t}, J_{\mathrm{C}-\mathrm{Rh}} \approx J_{\mathrm{C}-\mathrm{P}}=10.08,=\mathrm{CH} \operatorname{cod}\right), 85.6\left(\mathrm{~d}, J_{\mathrm{C}-\mathrm{P}}=\right.$ 8.1, $=\mathrm{CH} \operatorname{cod}), 31.3\left(\mathrm{CH}_{2} \operatorname{cod}\right), 30.7\left(\mathrm{CH}_{2} \mathrm{cod}\right)$. MS (MALDI-Tof, $\left.\mathrm{CH}_{2} \mathrm{Cl}_{2}, \mathrm{~m} / \mathrm{z}, \%\right): 474 \cdot 4\left([\mathrm{M}-\mathrm{C} \equiv \mathrm{CPh}]^{+}, 100\right)$.

Polymerization Reactions. The polymerization reactions were carried out in round bottom flasks with efficient stirring. A typical polymerization procedure is as follows: phenylacetylene (70 $\mu \mathrm{L}, 0.64 \mathrm{mmol}$ ) was added to a THF solution $(2.5 \mathrm{~mL})$ of the catalysts $(6.4 \mu \mathrm{mol})$ and the mixture stirred at $293 \mathrm{~K}$ in the absence of light. The consumption of monomer was monitored by GC using n-octane as internal standard. The polymer was isolated by precipitation into an excess of vigorously stirred, cold (273 $\mathrm{K})$ methanol $(25 \mathrm{~mL})$ using a cannula under $\mathrm{Ar}$, and the product was filtered and then washed with methanol, and dried under vacuum to constant weight. The polymers were obtained as yellow-orange solids in good yields.

Monitoring of the polymerization of phenylacetylene initiated by $\left[\mathrm{Rh}(\right.$ diene $\left.)\left(\mathrm{iPrNH}_{2}\right)\left(\mathrm{Ph}_{2} \mathrm{PPy}\right)\right]\left[\mathrm{BF}_{4}\right]$ complexes. An NMR tube was charged with a solution of compound $\left[\mathrm{Rh}(\mathrm{nbd})\left(\mathrm{iPrNH}_{2}\right)\left(\mathrm{Ph}_{2} \mathrm{PPy}\right)\right]^{+}$(7) $(0.022 \mathrm{mmol}, \quad 0.044 \mathrm{M})$ in $\mathrm{CD}_{2} \mathrm{Cl}_{2}(0.5 \mathrm{~mL})$ and then cooled to $195 \mathrm{~K}$. After addition of PA (o.11 mmol, o.22 M, $[\mathrm{PA}] /[7]=5 / 1$ ) the solution was monitored by ${ }^{31} \mathrm{P}\left\{{ }^{1} \mathrm{H}\right\} \mathrm{RMN}$ at $220 \mathrm{~K}$ after stirring at room temperature for certain time. The monitoring of the PA polymerization by $\left[\mathrm{Rh}(\mathrm{cod})\left(i \mathrm{PrNH}_{2}\right)\left(\mathrm{Ph}_{2} \mathrm{PPy}\right)\right]^{+}(\mathbf{8})$ was carried out following the same procedure using $8(0.018 \mathrm{mmol}, 0.036 \mathrm{M})$ and PA (o.09 mmol, o.18 M, $[\mathrm{PA}] /[8]=5 / 1)$ in $\mathrm{CD}_{2} \mathrm{Cl}_{2}(0.5 \mathrm{~mL})$.

Computational Details. DFT calculations performed in this work were carried out with the Gaussianog program (revision D.o1). ${ }^{85}$ The calculations were done using the B3LYP functional including Grimme $\mathrm{D}_{3}$ dispersion correction with Becke-Johnson type damping. ${ }^{86}$ For $\mathrm{Rh}$ atoms the LANL2DZ and its associated basis set supplemented with an f function was used. ${ }^{87}$ The 6${ }_{31} G(d, p)$ basis set was used for the rest of the atoms.

Crystal structure determinations. X-ray diffraction, data were collected on APEX SMART (XX) or APEX-DUO SMART (XX) Bruker diffractometers with graphite-monochromated Mo-K $\alpha$ radiation $(\lambda=0.71073 \AA)$ using narrow $\omega$ rotations $\left(0.3-0.6^{\circ}\right)$. Intensities were integrated and corrected for absorption effects with SAINT-PLUS, ${ }^{88}$ and SADABS ${ }^{89}$ programs, both included in APEX 2 package. The structures were solved by the Patterson method with SHELXS-2013 ${ }^{90}$ and refined by full matrix leastsquares on $F^{2}$ with SHELXL-2014 ${ }^{91}$ under WinGX. ${ }^{92}$ Single crystals for the X-ray diffraction studies were grown by slow evaporation of an acetone solution of $\mathbf{1 2}$ and slow diffusion of diethyl ether into a concentrated acetone solution of $\mathbf{1 4}$.

Crystal data and structure refinement for 12. $\mathrm{C}_{42} \mathrm{H}_{41} \mathrm{BF}_{4} \mathrm{NOPRh}_{2}, \mathrm{M}=899.36 \mathrm{~g} \mathrm{~mol}^{-1}, \mathrm{~T}=100(2) \mathrm{K}$, orthorhombic, $\mathrm{P}_{21} 2_{1} 2_{1}, \mathrm{a}=10.327(2) \AA, \mathrm{b}=18.323(4) \AA, \mathrm{c}=19.587(4) \AA$, $\mathrm{V}=3706.4(13) \AA^{3}, \mathrm{Z}=4, \mathrm{D}_{\text {calc }}=1.612 \mathrm{Mg} \mathrm{m}^{3}, \mu=0.989 \mathrm{~mm}^{-1}$, red prism, $0.120 \times 0.130 \times 0.130 \mathrm{~mm}^{3}, \square \min / \square$ max $1.522 / 26.370^{\circ}$, reflections collected/unique 40245/7583 [R(int) $=0.0449]$, data/restraints/parameters 7583/80/487, GOF $=1.065, \mathrm{R} 1=0.0245$ $[\mathrm{I}>2 \square(\mathrm{I})], \mathrm{wR} 2=0.0567$ (all data), absolute structure parameter 0.028(12), largest diff. peak/hole 0.532/-0.317 e $\AA^{-3}$.

Crystal data and structure refinement for 14 . $\mathrm{C}_{54} \mathrm{H}_{48} \mathrm{BF}_{4} \mathrm{~N}_{3} \mathrm{OP}_{3} \mathrm{Rh}, \mathrm{M}=1037.58 \mathrm{~g} \mathrm{~mol}^{-1}, \mathrm{~T}=143(2) \mathrm{K}$, orthorhombic, $\mathrm{P}_{2} 2_{1} 2_{1}, \mathrm{a}=14.259$ (4) $\AA, \mathrm{b}=17.335$ (5) $\mathrm{A}, \mathrm{c}=19.981(5) \AA$, $\mathrm{V}=4939(2) \AA^{3}, \mathrm{Z}=4, \mathrm{D}_{\text {calc }}=1.395 \mathrm{Mg} \mathrm{m}^{-3}, \mu=0.500 \mathrm{~mm}^{-1}$, orange prism, $0.040 \times 0.110 \times 0.240 \mathrm{~mm}^{3}, \square$ min $/ \square_{\max } 1.555 / 26.372^{\circ}$, reflections collected/unique 63721/10091 $[\mathrm{R}$ (int) $=0.0657]$, da- $\mathrm{ta} /$ restraints/parameters 10091/59/571, GOF $=1.026, \quad \mathrm{R} 1=$ $0.0386[\mathrm{I}>2 \square(\mathrm{I})], \mathrm{wR}_{2}=0.0921$ (all data), absolute structure parameter-0.013(13), largest diff. peak/hole 0.717/-0.419 e $\AA^{-3}$

\section{Acknowledgements}

Financial support from the Spanish Ministry of Economy and Competitiveness (MINECO/FEDER) under the Project CTQ2016-75884-P and the Diputación General de Aragón (DGA/FSE-Eo7) is gratefully acknowledged. The authors thankfully acknowledge the resources from the supercomputer "Caesaraugusta" (node of the Spanish Supercomputer Network), technical expertise and assistance provided by BIFI-Universidad de Zaragoza.

\section{ASSOCIATE CONTENT}

Supporting Information. The Supporting Information is available free of charge on the ACS Publications website at DOI: \#\#\#\#. NMR spectra for selected compounds (PDF). Electronic energy, enthalpy, and free energy and optimized coordinates for the computed compounds (XYZ). Accession Codes. CCDC \#\#\#-\#\#\# contain the supplementary crystallographic data for this paper. These data can be obtained free of charge via www.ccdc.cam.ac.uk/data_request/cif, or by emailing data_request@ccdc.cam.ac.uk, or by contacting The Cambridge Crystallographic Data Centre, 12 Union Road, Cambridge CB2 1EZ, UK; fax: +44 1223336033 .

\section{AUTHOR INFORMATION}

\section{Corresponding Authors.}

*E-mail: perez@unizar.es.

*E-mail: vjimenez@unizar.es.

\section{ORCID}

M. Victoria Jiménez: oooo-0oo2-0545-9107

F. Javier Modrego: oooo-0oo2-9633-3285

Luis A. Oro: \#\#\#\#\#

Vincenzo Passarelli: oooo-0oo2-1735-6439

Jesús J. Pérez-Torrente: oooo-0oo2-3327-0918

\section{Notes}

The authors declare no competing financial interest.

\section{REFERENCES}

(1) Sadimenko, A. P. Organometallic Complexes of Phosphinopyridines and Related Ligands. Adv. Heterocycl. Chem. 2011, 104, 391-478 475 .

(2) Newcome, R. Pyridylphosphines. Chem. Rev. 1993, 93, 20672089.

(3) Zhang, Z.Z.; Cheng, H. Chemistry of 2(diphenylphosphino)pyridine. Coord. Chem. Rev. 1996, 147, 1-39.

(4) Fereidoonnezhad, M.; Niazi, M.; Ahmadipour, Z.; Mirzaee, T.; Faghih, Z.; Faghih, Z.; Shahsavari, H. R. Cyclometalated Platinum(II) Complexes Comprising 2-(Diphenylphosphino)pyridine and Various Thiolate Ligands: Synthesis, Spectroscopic Characterization, and Biological Activity. Eur. J. Inorg. Chem. 2017, 2247-2254.

(5) Carson, E. C.; Lippard, S. J. Dioxygen-Initiated Oxidation of Heteroatomic Substrates Incorporated into Ancillary Pyridine 
Ligands of Carboxylate-Rich Diiron(II) Complexes. Inorg. Chem. 2006, 45, 837-848.

(6) Wajda-Hermanowicz, K.; Ciunik, Z.; Kochel, A. Syntheses and Molecular Structure of Some Rh and Ru Complexes with the Chelating Diphenyl (2-Pyridyl)phosphine Ligand. Inorg. Chem. 2006, 45, 3369-3377.

(7) Liu, J.; Jacob, C.; Sheridan, K. J.; Al-Mosule, F.; Heaton, B. T.; Iggo, J. A.; Matthews, M.; Pelletier, J.; Whyman, R.; Bickley, J. F.; Steiner, A. The synthesis of, and characterization of the dynamic processes occurring in $\mathrm{Pd}(\mathrm{II})$ chelate complexes of 2pyridyldiphenylphosphine. Dalton Trans. 2010, 39, 7921-7935.

(8) Maggini, S. Classification of P,N-binucleating ligands for hetero- and homobimetallic complexes. Coord. Chem. Rev. 2009, 253, 1793-1832.

(9) Arena, C. G.; Rotondo, E.; Faraone, F. Steric effects of the 2(diphenylphosphino)pyridine bridging ligand in the synthesis of binuclear rhodium-palladium complexes. Crystal structures of $\left[(\mathrm{CN} \text {-tert-Bu })_{2} \mathrm{Cl}_{2} \mathrm{Rh}\left(\mu-\mathrm{Ph}_{2} \mathrm{PPy}\right) \mathrm{Pd}(\mu-\mathrm{Cl})\right]_{2}$ and $\quad\left[\left(\mathrm{C}_{8} \mathrm{H}_{12}\right) \mathrm{Rh}(\mu-\right.$ $\left.\mathrm{Cl})\left(\mu-\mathrm{Ph}_{2} \mathrm{PPy}\right) \mathrm{PdCl}_{2}\right]$. Organometallics 1991, 10, 3877-3885.

(10) Reinhard, G.; Hirle, B.; Schubert, U.; Knorr, M.; Braunstein, P.; DeCian, A.; Fischer, J. Transition-metal silyl complexes. 46. Reaction of anionic silyl complexes $\left[\mathrm{Fe}(\mathrm{CO})_{3}\left(\mathrm{SiR}_{3}\right)\left(\mathrm{PR}_{3}^{\prime}\right)\right]$ - with $\mathrm{CdX}_{2}(\mathrm{X}=\mathrm{Cl}, \mathrm{Br})$ to probe the influence of the phosphines $\mathrm{PR}_{3}$, and $\mathrm{X}$ on nuclearity and geometry of the resulting polynuclear complexes. Inorg. Chem. 1993, 32, 1656-1661.

(11) Chen, K.; Shearer, J.; Catalano. V. J. Subtle Modulation of $\mathrm{Cu}_{4} \mathrm{X}_{4} \mathrm{~L}_{2}$ Phosphine Cluster Cores Leads to Changes in Luminescence. Inorg. Chem. 2015, 54, 6245-6256.

(12) Wang, Q.-M.; Lee, Y.-A.; Crespo, O.; Deaton, J.; Tang, C.; Gysling, H. J.; Gimeno, M. C.; Larraz, C.; Villacampa, M. D.; Laguna, A.; Eisenberg, R. Intensely Luminescent Gold(I)-Silver(I) Cluster Complexes with Tunable Structural Features. J. Am. Chem. Soc. 2004, 126, 9488-9489.

(13) Espinet, P.; Soulantica, K. Phosphine-pyridyl and related ligands in synthesis and catalysis. Coord. Chem. Rev. 1999, 193195, 499-556.

(14) Grotjahn, D. B. Heteroatoms moving protons: Synthetic and mechanistic studies of bifunctional organometallic catalysis. Pure Appl. Chem. 2010, 82, 635-647

(15) Grotjahn, D. B. Structures, Mechanisms, and Results in Bifunctional Catalysis and Related Species Involving Proton Transfer. Top. Catal. 2010, 53, 1009-1014.

(16) Oshiki, T.; Yamashita, H.; Sawada, K.; Utsunomiya, M.; Takahashi K.; Takai, K. Dramatic Rate Acceleration by a Diphenyl-2-pyridylphosphine Ligand in the Hydration of Nitriles Catalyzed by $\mathrm{Ru}(\mathrm{acac})_{2}$ Complexes. Organometallics 2005, 24, 62876290.

(17) Muranaka, M.; Hyodo, I.; Okumura, W.; Oshiki, T. 2Diphenylphosphanyl-4-pyridyl(dimethyl)amine as an effective ligand for the ruthenium(II) complex catalyzed homogeneous hydration of nitriles under neutral conditions. Catal. Today 2011, $164,552-555$.

(18) García-Álvarez, R.; García-Garrido, S. E.; Díez, ; Crochet, P.; Cadierno, V. Arene-Ruthenium(II) and Bis(allyl)-Ruthenium(IV) Complexes Containing 2-(Diphenylphosphanyl)pyridine Ligands: Potential Catalysts for Nitrile Hydration Reactions? Eur. J. Inorg. Chem. 2012, 4218-4230.

(19) Grotjahn, D. B.; Lev, D. A. A General Bifunctional Catalyst for the Anti-Markovnikov Hydration of Terminal Alkynes to Aldehydes Gives Enzyme-Like Rate and Selectivity Enhancements. J. Am. Chem. Soc. 2004, 126, 12232-12233.

(20) Hintermann, L.; Dang, T. T.; Labonne, A., Kribber, T.; Xiao, L.; Naumov, P. The AZARYPHOS Family of Ligands for Ambifunctional Catalysis: Syntheses and Use in Ruthenium-
Catalyzed anti-Markovnikov Hydration of Terminal Alkynes. Chem. Eur. J. 2oo9, 15, 7167-7179.

(21) Boeck, F; Kribber, T.; Xiao, L.; Hintermann, L. Mixed Phosphane $\eta_{5}-\mathrm{CpRuCl}\left(\mathrm{PR}_{3}\right)_{2}$ Complexes as Ambifunctional Catalysts for Anti-Markovnikov Hydration of Terminal Alkynes. J. Am. Chem. Soc., 2011, 133, 8138-814.

(22) Landman, I. R.; Paulson, E. R.; Rheingold, A. L.; Grotjahn, D. B.; Rothenberg G. Designing bifunctional alkene isomerization catalysts using predictive modeling. Catal. Sci. Technol. 2017, 7, 4842-4851.

(23) Erdogan, G.; Grotjahn, D. B. Catalysis of Selective Hydrogen/Deuterium Exchange at Allylic Positions Using Deuterium Oxide. Top. Catal. 2010, 53,1055-1058.

(24) Landaeta, V. R.; Rodríguez-Lugo, R. E. Insights on the $\mathrm{CH}$ Bond activation by Transition Metal Complexes from Groups 810 Bearing (P-N) Chelates. J. Mol. Catal. A: Chemical 2017, 426, 316-325.

(25) Drent, E.; Arnoldy, P.; Budzelaar, P. H. M. Homogeneous catalysis by cationic palladium complexes. Precision catalysis in the carbonylation of alkynes. J. Organomet. Chem. 1994, 475, 5763.

(26) Tanga, C.-M.; Zenga, Y.; Yanga, X.-G.; Leia, Y.-C.; Wang, G.$\mathrm{Y}$. The palladium catalyzed hydrocarboxylation of acetylene with carbon monoxide to acrylic acid under mild conditions. J. Mol. Catal. A: Chemical 2009, 314, 15-20.

(27) Scrivanti, A.; Beghetto, V.; Bertoldini, M. New insights into the alkoxycarbonylation of propargyl alcohol. Molecular Catalysis 2017, 443, 38-42.

(28) Masuda, T. Substituted Polyacetylenes: Synthesis, Properties, and Functions. Polym. Rev. 2016, 57, 1-14.

(29) Xu, A.; Masuda, T.; Zhang, A. Stimuli-Responsive Polyacetylenes and Dendronized Poly(phenylacetylene)s. Polym. Rev. 2016, $57,138-158$

(30) Casado, M. A.; Fazal, A.; Oro, L. A. Rhodium-Catalyzed Polymerization of Phenylacetylene and its Derivatives. Arab. J. Eng. 2013, 38, 1631-1646.

(31) Sedláček, J.; Vohlídal, J. Controlled and Living Polymerizations Induced with Rhodium Catalysts. A Review Collect. Czech. Chem. Commun. 2003, 68, 1745-1790.

(32) Jiménez, M. V.; Pérez-Torrente, J. J.; Bartolomé, M. I.; Vispe, E.; Lahoz, F. J.; Oro, L. A. Cationic Rhodium Complexes with Hemilabile Phosphine Ligands as Polymerization Catalyst for High Molecular Weight Stereoregular Poly(phenylacetylene). Macromolecules 2009, 42, 8146-8156.

(33) Angoy, M.; Bartolomé, M. I.; Vispe, E.; Lebeda, P.; Jiménez, M. V.; Pérez-Torrente, J. J.; Collins, S.; Podzimek, S. Branched Poly(phenylacetylene). Macromolecules 2010, 43, 6278-6283.

(34) Kishimoto, Y.; Miyatake, T.; Ikariya, T.; Noyori, R. An Efficient Rhodium(I) Initiator for Stereospecific Living Polymerization of Phenylacetylenes. Macromolecules 1996, 29, 5054-5055.

(35) Kishimoto, Y.; Eckerle, P.; Miyatake, T.; Kainosho, M.; Ono, A.; Ikariya, T.; Noyori, R. Mixed Phosphane $\eta^{5}-\mathrm{CpRuCl}\left(\mathrm{PR}_{3}\right)_{2}$ Complexes as Ambifunctional Catalysts for Anti-Markovnikov Hydration of Terminal Alkynes. J. Am. Chem. Soc. 1999, 121, 12035-12044.

(36) Shiotsuki, M.; Onishi, N.; Sanda, F.; Masuda, T. Living polymerization of phenylacetylenes catalyzed by cationic rhodium complexes bearing tetrafluorobenzobarrelene. Polym. J. 2011, 43, 51-57.

(37) Komatsu, H.; Suzuki, Y.; Yamazaki, H. Unprecedented Rhodium-Mediated Tetramerization of Bulky Terminal Alkynes Leading to Hydropentalenylrhodium Complexes. Chem. Lett. 2001, 30, 998-999. 
(55) Cowie, M.; Loeb, S. J. Structure of $\left[\mathrm{Rh}_{2}(\mathrm{CO})_{2}(\mu-\right.$ $\left.\left.\mathrm{C}_{2} \mathrm{CMe}_{3}\right)\left(\mathrm{Ph}_{2} \mathrm{PCH}_{2} \mathrm{PPh}_{2}\right)_{2}\right]\left[\mathrm{ClO}_{4}\right] \cdot 0.866 \mathrm{CH}_{2} \mathrm{Cl}_{2}:$ an "A-frame"

(39) Brück, A.; Ruhland, K. Investigation of the Dynamic Solution Behavior of Chloro(diene)rhodium(I) Phosphine Complexes with a Pendant Unsaturated Heterocycle at Phosphorus (2pyridyl, 2-imidazyl; diene $=$ COD, NBD). Organometallics 2oo9, $28,6383-6401$.

(40) Nishide, K.; Ito, S.; Yoshifuji, M. Preparation of carbonyltungsten(o) complexes of 2-pyridylphosphines showing a stepwise coordination pattern by way of monodentate to chelate mode. J. Organomet. Chem. 2003, 682, 79-84.

(41) Kumar, P.; Singh, A. K.; Pandey, R.; Pandey, D. S. Biocatalysts and catalysts based on ruthenium(II) polypyridyl complexes imparting diphenyl-(2-pyridyl)-phosphine as a co-ligand. J. Organomet. Chem. 2011, 696, 3454-3464.

(42) Oro, L. A.; Ciriano, M. A.; Pérez-Torrente, J. J.; Villarroya, B. E. Controlling the molecular architecture of low nuclearity rhodium and iridium complexes using bridging $\mathrm{N}-\mathrm{C}-\mathrm{X}(\mathrm{X}=\mathrm{N}, \mathrm{O}, \mathrm{S})$ ligands. Coord. Chem. Rev. 1999, 193-195, 941-975.

(43) Morvillo, A.; Bressan, M. Preparation and reactivity of new dioxygen adducts of rhodium containing phosphine ligands. Inorg. Chim. Acta 1986, 121, 219-222.

(44) Saeed, I.; Shiotsuki, M.; Masuda, T. Effect of Diene Ligands in the Rhodium-Catalyzed Polymerization of Phenylacetylene. Macromolecules 2006, 39, 8977-8981.

(45) Onishi, N.; Shiotsuki, M.; Sanda, F.; Masuda, T. Polymerization of Phenylacetylenes with Rhodium Zwitterionic Complexes: Enhanced Catalytic Activity by $\pi$-Acidic Diene Ligands. Macromolecules 2009, 42, 4071-4076.

(46) Furlani, A.; Napoletano, C.; Russo, M. V.; Camus, A.; Marsich, N. J. The influence of the ligands on the catalytic activity of a series of $R h^{1}$ complexes in reactions with phenylacetylene: Synthesis of stereoregular poly(phenyl) acetylene. Polym. Sci., Part A: Polym. Chem. 1989, 27, 75-86.

(47) Furlani, A.; Napoletano, C.; Russo, M. V.; Feast, W. J. Stereoregular polyphenylacetylene. Polym. Bull. 1986, 16, 311-317.

(48) Shiotsuki, M.; Onishi, N.; Sanda, F.; Masuda, T. Living Polymerization of Phenylacetylene Catalyzed by a Cationic Rh Complex Bearing Tetrafluorobenzobarrelene. Chem. Lett. 2010, $39,244-245$

(49) George, D. S. A.; Hilts, R. W.; McDonald, R.; Cowie, M. An Unusual Example of Allyl-to-Alkynyl Migration in a Phenylacetylide-Bridged Heterobinuclear Complex of Rhodium and Iridium. Organometallics 1999, 18, 5330-5343.

(50) Cordero, B.; Gómez, V.; Platero-Prats, A. E.; Revés, M.; Echeverría, J.; Cremades, E.; Barragán, F.; Alvarez, S. Covalent radii revisited. Dalton Trans. 20o8, 2832-2838.

(51) 2-(Diphenylphosphino)pyridine as a bridging ligand. Synthesis and structure of $\mathrm{Rh}_{2}\left(\mathrm{Ph}_{2} \mathrm{Ppy}\right)_{2}(. \mathrm{mu} .-\mathrm{CO}) \mathrm{Cl}_{2}$ and RhPd(Ph2Ppy)2(CO)Cl 3 Farr, J. P.; Olmstead, M. M.; Balch, A. L. J. Am. Chem. Soc. 1980, 102, 6654-6656.

(52) Synthesis, oxidative addition, and structural studies of the metal-metal bonded bimetallic complexes [(.eta.5 $\left.\left.\mathrm{C}_{5} \mathrm{H}_{5}\right) \mathrm{Rh}(. \mathrm{mu} . \mathrm{CO})\left(. \mathrm{mu}^{-} \mathrm{Ph}_{2} \mathrm{PC}_{5} \mathrm{H}_{4} \mathrm{~N}\right) \mathrm{M}(\mathrm{CO}) \mathrm{Cl}\right] \quad(\mathrm{M}=\mathrm{Rh}, \mathrm{Ir})$ Bruno, G.; Schiavo, S. L.; Rotondo, E.; Arena, C. G.; Faraone, F. Organometallics 1989, 8, 886-892.

(53) Binuclear rhodium hydride complexes: synthesis, structure, and reactivity, Shafiq, F.; Eisenberg, R. Inorg. Chem. 1993, 32, 3287-3294.

(54) Synthesis and structures of (3-methyl-2pyridyl)diphenylphosphane derivatives of metal clusters Jaaskelainen, S.; Haukka, M.; Riihimaki, H.; Pursiainen, J. T.; Pakkanen, T. A. J. Organomet. Chem. 2004, 689, 1064-1070. compound containing a $\sigma, \pi$-acetylido group. Organometallics, 1985, 4, 852-857.

(56) Synthesis, characterization, and reactivity of rhodium carboxylate dimers $\left[\mathrm{Rh}\left(\mu-\mathrm{OOCCR}_{3}\right)(\mathrm{CO})\left(\mathrm{PCy}_{3}\right)\right]_{2}(\mathrm{R}=\mathrm{H}, \mathrm{F})$. X-ray crystal structure of $\left[\mathrm{Rh}_{2}\left(\mu-\mathrm{OOCCH}_{3}\right)\left(\mu-\eta^{1}: \eta^{2}-\right.\right.$ $\left.\mathrm{C}_{2} \mathrm{Ph}\right)(\mathrm{CO})_{2}\left(\mathrm{PCy}_{3}\right)_{2}$ ]. Esteruelas, M. A.; Lahuerta, O.; Modrego, J.; Nurnberg, O.; Oro, L. A.; Rodriguez, L.; Sola, E.; Werner, H. Organometallics, 1993, 12, 266-275

(57) Komatsu, H.; Suzuki, Y.; Yamazaki, H. Unprecedented Rhodium-Mediated Tetramerization of Bulky Terminal Alkynes Leading to Hydropentalenylrhodium Complexes. Chem. Lett. 2001, 998-999.

(58) Tanaka, S.; Dubs, C.; Inagaki, A.; Akita, M. Polynuclear Rhodium Complexes with Dinucleating PNNP Ligand: Dynamic and Diverse $\mathrm{M} \cdots \mathrm{M}$ Interactions in $\left[(\mu-\mathrm{X}) \mathrm{Rh}_{2}(\mathrm{PNNP})(\mathrm{CO})_{2}\right]^{\mathrm{n}+}$ and $\left[\left(\mu^{4}-\mathrm{X}\right) \mathrm{Rh}_{4}(\mathrm{PNNP})_{2}(\mathrm{CO})_{4}\right]^{\mathrm{n}+}[\mathrm{X}=\mathrm{H}, \mathrm{O}, \mathrm{CC}-\mathrm{R}, \mathrm{R}-\mathrm{CC}-\mathrm{R}, \mathrm{CC}$, $\mathrm{CHCH}_{2}, \quad \mathrm{SMe}_{2} ; \mathrm{n}=0, \quad$ : $\mathrm{PNNP}=3,5$ bis(diphenylphosphinomethyl)pyrazolato] Organometallics 2005, 24, 163-184.

(59) Dubs, C.; Yamamoto, T.; Inagaki, A.; Akita, M. Synthesis of a Library of Iridium-Containing Dinuclear Complexes with Bridging PNNN and PNNP Ligands (BL), [LM( $\mu$-BL)M'L']BF . 2. Preparation, Basic Coordination Properties, and Reactivity of the Carbonyl Complexes Organometallics 20o6, 25, 1359-1367.

(60) Yamaguchi, T.; Koike, T.; Akita, M. Dirhodium Complexes Bridged by Bis(diphenylphosphino)phthalazine $\left(\mathrm{PNNP}^{\mathrm{Ph}}\right)$ : Central Ring Size and Charge Effects As Compared with the Pyrazolate Derivative (PNNP ${ }^{\mathrm{Py}}$ ) Organometallics 2010, 29, 6493-6502.

(61) Gondoh, A.; Koike, T.; Akita, M. 3,5Bis(diphenylphosphinoethyl)pyrazolate ligand ( $\mathrm{PNNP}^{\mathrm{C}_{2}}$ ) and its dirhodium complexes: Comparison with related quadridentate dinucleating diphenylphosphinomethyl $\left(\mathrm{PNNP}^{\mathrm{Py}}\right)$ and phthalazine derivatives $\left(\mathrm{PNNP}^{\mathrm{Ph}}\right)$. Inorg. Chim. Acta 2o11, 374, 489-498. (62) Ogata, K.; Ohashi, I.; Fukuzawa, S. Rhodium-Catalyzed Three-Component Reaction between Silylacetylene and Two Ketenes Leading to 1,3-Enynes Bearing a Carboxylic Ester Group via Double Insertion of Ketenes. Org. Lett. 2012, 14, 4214-4217.

(63) George, D. S. A.; McDonald, R.; Cowie, M. Reactivity of the Heterobinuclear Phenylacetylide-Bridged A-Frame $\left[\mathrm{RhIr}(\mathrm{CO})_{2}(\mu-\mathrm{CCPh})\left(\mathrm{Ph}_{2} \mathrm{PCH}_{2} \mathrm{PPh}_{2}\right)_{2}\right]\left[\mathrm{O}_{3} \mathrm{SCF}_{3}\right]$ with Small Molecules. Organometallics 1998, 17, 2553-2566.

(64) Grotjahn, D. B.; Miranda-Soto, V.; Kragulj, E. J.; Lev, D. A.; Erdogan, G.; Zeng, X.; Cooksy, A. L. Hydrogen-Bond Acceptance of Bifunctional Ligands in an Alkyne-Metal $\pi$ Complex. J. Am. Chem. Soc. 2008, 130, 20-21.

(65) Grotjahn, D. B.; Zeng, X.; Cooksy, A. L.; Kassel, W. S.; DiPasquale, A. G.; Zakharov, L. N.; Rheingold. A. L. Experimental and Computational Study of the Transformation of Terminal Alkynes to Vinylidene Ligands on trans(Chloro)bis(phosphine)Rh Fragments and Effects of Phosphine Substituents. Organometallics 2007, 26, 3385-3402.

(66) Cowley, M. J.; Lynam, J. M.; Slattery, J. M. A mechanistic study into the interconversion of rhodium alkyne, alkynyl hydride and vinylidene complexes. Dalton Trans. 2oo8, 4552-4554. (67)Lynam, J. M. Recent Mechanistic and Synthetic Developments in the Chemistry of Transition-Metal Vinylidene Complexes. Chem. -Eur. J. 2010, 16, 8238-8247.

(68) Álvarez, E.; Hernández, Y. A.; López-Serrano, J.; Maya, C.; Paneque, M.; Petronilho, A.; Poveda, M. L.; Salazar, V.; Vattier, F.; Carmona, E. Metallacyclic Pyridylidene Structures from Reactions of Terminal Pyridylidenes with Alkenes and Acetylene. Angew. Chem. Int. Ed. 2010, 49, 3496-3499. 
(69) Grotjahn, D. B. Bifunctional Organometallic Catalysts Involving Proton Transfer or Hydrogen Bonding. Chem. -Eur. J. 2005, 11, 7146-7153.

(70) Bajo, S.; Esteruelas, M. A.; López, A. M; Oñate, E. Alkenylation of 2-Methylpyridine via Pyridylidene-Osmium Complexes. Organometallics 2012, 31, 8618-8626.

(71) Rani, P. U., Reddy, P. M.; Shanker, K.; Ravinder, V. Synthesis, characterization and catalytic applications of rhodium(I) organometallics with substituted tertiary phosphines. Trans. Met. Chem. 2008, 33, 153-16o.

(72) Puckering parameter $\mathrm{q}_{2}=0.0315(0.0010)$. See Cremer D.; Pople J. A. General definition of ring puckering coordinates. J. Am. Chem. Soc. 1975, 97, 1354-1358.

(73) Deshmukh, K.; Siddiqui, S.; Coetzee, J. F. Characterization of Tetrahydrofuran as a Solvent for Proton Transfer Reactions. J. Electrochem. Soc. 1991, 138, 124-132.

(74)Hall, H. K., Jr. Correlation of the Base Strengths of Amines. J. Am. Chem. Soc. 1957, 79, 5441-5444.

(75) Bintein S.; Devillers. J. QSAR for organic chemical sorption in soils and sediments. Chemosphere 1994, 28, 1171-1188.

(76) Ke, Z.; Abe, S.; Ueno, T.; Morokuma, K. Rh-Catalyzed Polymerization of Phenylacetylene: Theoretical Studies of the Reaction Mechanism, Regioselectivity, and Stereoregularity. J. Am. Chem. Soc. 2011, 133, 7926-7941.

(77) Giordano, G.; Crabtree, R. H. Di- $\mu$-Chloro-Bis $\left(\eta^{4}-1,5^{-}\right.$ Cyclooctadlene) Dirhodium(I). Inorg. Synth. 1979, 19, 218-219.

(78) Abel, E. W.; Benett, M. A.; Wilkinson, G. Norbornadienemetal complexes and some related compounds. J. Chem. Soc. 1959, 3178-3182.

(79) Usón, R.; Oro, L. A.; Cabeza, J. A. Dinuclear Methoxy, Cyclooctadiene, and Barrelene Complexes of Rhodium(I) and Iridium(I). Inorg. Synth. 1985, 23, 126-130.

(80) Ulmer, L.; Mattay, J.; Torres-García, H. G.; Luftmann, H. The Use of 2-[(2E)-3-(4-Tert-Butylphenyl)-2-Methylprop-2Enylidene]Malononitrile as a Matrix for Matrix-Assisted Laser Desorption/Ionization Mass Spectrometry. Eur. J. Mass Spectrom. 200o, 6, 49-52.

(81) Sedlacek, J.; Vohlidal, J.; Grubisic-Gallot, Z. Molecularweight determination of poly(phenyl-acetylene) by size exclusion chromathography/low-angle laser light scattering. Influence of polymer degradation. Makromol. Chem., Rapid. Commun. 1993, 14, 51-53.

(82) Percec, V.; Rudick, J. G. G. Independent Electrocyclization and Oxidative Chain Cleavage along the Backbone of cisPoly(phenylacetylene). Macromolecules 2005, 38, 7241-7250.

(83) Sedlacek, J.; Vohlidal, J.; Grubisic-Gallot, Z. Makromo

Chem., Rapid. Commun. 1993, 14, 51-53. REPITE REF. 8

(84) Podzimek, S. Light Scattering, Size Exclusion Chromatography and Asymmetric Flow Field Flow Fractionation, John Wiley and Sons, Hoboken, New Jersey, 2011, pp 65-72.

(85) Frisch, M. J.; Trucks, G. W.; Schlegel, H. B.; Scuseria, G. E.; Robb, M. A.; Cheeseman, J. R.; Scalmani, G.; Barone, V.; Mennucci, B.; Petersson, G. A.; Nakatsuji, H.; Caricato, M.; Li, X.; Hratchian, H. P.; Izmaylov, A. F.; Bloino, J.; Zheng, G.; Sonnenberg, J. L.; Hada, M.; Ehara, M.; Toyota, K.; Fukuda, R.; Hasegawa, J.; Ishida, M.; Nakajima, T.; Honda, Y.; Kitao, O.; Nakai, H.; Vreven, T.; Montgomery, J. A.; Peralta, J. E.; Ogliaro, F.; Bearpark, M.; Heyd, J. J.; Brothers, E.; Kudin, K. N.; Staroverov, V. N.; Kobayashi, R.; Normand, J.; Raghavachari, K.; Rendell, A.; Burant, J. C.; Iyengar, S. S.; Tomasi, J.; Cossi, M.; Rega, N.; Millam, J. M.; Klene, M.; Knox, J. E.; Cross, J. B.; Bakken, V.; Adamo, C.; Jaramillo, J.; Gomperts, R.; Stratmann, R. E.; Yazyev, O.; Austin, A. J.; Cammi, R.; Pomelli, C.; Ochterski, J. W.; Martin, R. L.; Morokuma, K.; Zakrzewski, V. G.; Voth, G. A.; Salvador, P.;
Dannenberg, J. J.; Dapprich, S.; Daniels, A. D.; Farkas; Foresman, J. B.; Ortiz, J. V.; Cioslowski, J.; Fox, D. J. Gaussian o9, Revision D.o1, Gaussian, Inc., Wallingford CT 2009.

(86) Grimme, S.; Ehrlich, S.; Goerigk, L. Effect of the damping function in dispersion corrected density functional theory. $J$. Comput. Chem. 2011, 32, 1456-1465.

(87) Ehlers, A. W.; Böhme, M.; Dapprich, S.; Gobbi, A.; Höllwarth, A.; Jonas, V.; Köhler, K. F.; Stegmann, R.; Veldkamp, A.; Frenking, G. A set of f-polarization functions for pseudopotential basis sets of the transition metals $\mathrm{Sc}-\mathrm{Cu}, \mathrm{Y}-\mathrm{Ag}$ and $\mathrm{La}-$ Au Chem. Phys. Lett. 1993, 208, 111-114.

(88) SAINT-PLUS: Area-Detector Integration Software, version 6.o1; Bruker AXS: Madison, WI, 2001.

(89) SADABS program; University of Göttingen: Göttingen, Germany, 1999.

(90) Sheldrick, G. M. A short history of SHELX. Acta Cryst. 2oo8, A64, 112-122.

(91)Sheldrick, G. M. Crystal structure refinement with SHELXL. Acta Cryst. 2015, $C_{71}, 3-8$.

(92) Farrugia, L. J. WinGX and ORTEP for Windows: an update. J. Appl. Crystallogr. 2012, 45, 849-854. 